\title{
AVALIAÇÃO CLÍNICA E MICROBIOLÓGICA DA SAÚDE PERIODONTAL DE CRIANÇAS PORTADORAS DE FISSURA COMPLETA DE LÁBIO E PALATO UNILATERAL COMPARADA A DE CRIANÇAS SEM FISSURAS NA MESMA FAIXA ETÁRIA (5 - 6 ANOS)
}

\section{BEATRIZ COSTA}

Tese apresentada à Faculdade de Odontologia de Bauru, da Universidade de São Paulo, como parte dos requisitos para obtenção do título de Doutor em Odontologia, na Área de Odontopediatria. 


\section{AVALIAÇÃO CLÍNICA E MICROBIOLÓGICA DA SAÚDE PERIODONTAL DE CRIANÇAS PORTADORAS DE FISSURA COMPLETA DE LÁBIO E PALATO UNILATERAL COMPARADA A DE CRIANÇAS SEM FISSURAS NA MESMA FAIXA ETÁRIA (5 - 6 ANOS)}

\section{BEATRIZ COSTA}

Tese apresentada à Faculdade de Odontologia de Bauru, da Universidade de São Paulo, como parte dos requisitos para obtenção do título de Doutor em Odontologia, na Área de Odontopediatria.

(EDIÇÃO REVISTA)

ORIENTADORA: PROFA ${ }^{A}$ DR ${ }^{A}$. ODILA PEREIRA DA SILVA ROSA 


\section{Costa, Beatriz \\ C 823 a Avaliação clínica e microbiológica da saúde periodontal de crianças portadoras de fissura completa de lábio e palato unilateral comparada a de crianças sem fissura na mesma faixa etária (5 - 6 anos) / Beatriz Costa. - - Bauru; 2000. 170p. : il. ; $30 \mathrm{~cm}$. \\ Tese. (Doutorado) -- Faculdade de Odontologia de Bauru, USP.}

Orientadora : Prof $^{a}$. Dr ${ }^{\mathrm{a}}$. Odila Pereira da Silva Rosa

Autorizo, exclusivamente para fins acadêmicos e científicos, a reprodução total ou parcial desta tese, por processos fotocopiadores e outros meios eletrônicos.

Assinatura do autor:

Bauru, 02 de fevereiro de 2000 


\section{DADOS CURRICULARES}

09 de outubro de 1959

Campinas, SP

Nascimento

$1979-1982$

Curso de Odontologia - Faculdade

de Odontologia de Bauru - USP

$1983-1985$

Residência Odontológica em Odontopediatria - HPRLLP - USP Bauru

$1983-1984$

Curso de Especialização em

Odontopediatria - FOB - USP.

$1984-1985$

Curso de Atualização em Ortodontia Preventiva - PROFIS - Bauru.

1986

Odontopediatra do HPRLLP - USP Bauru.

$1992-1995$

Curso de Mestrado em Odontopediatria - pela Faculdade de Odontologia de Bauru - USP.

$1995-2000$

Curso de Doutorado em Odontopediatria - pela Faculdade de Odontologia de Bauru - USP.

Associações

SBPqO - Sociedade Brasileira de Pesquisas Odontológicas. 
“A vida não é uma viagem em si .

Não é uma meta. É um processo.

A gente chega lá passo a passo.

E se cada passo for maravilhoso,

e se cada passo for mágico,

é a ssi m que será a vida..."

\section{( a utor desconhecido)}




\section{À DEUS,}

...pela presença constante em minha vida

...pela força para enfrentar as dificuldades

...pela quietude para alcançar a paz

\section{À minha família,}

...essên cia da minha vida,

pel o a mor, pa ci ên cia e compreen sã o,

pelos sa crifícios partilhados nos momen tos de a u sên cia, mas sobretudo pela in esgotá vel fonte de estímulo para o meu a primoramento

\section{DEDI CO COM AMOR}

\section{ESTE TRABALHO}




\section{AGRADECI MENTO ESPECI AL}

\section{À Prof. Dra. Odila Pereira da Silva Rosa}

...pela orientação deste trabalho,

pela hon estidade profissional, segura nça, incentivo transmitidosno dia a dia e, a cima de tudo, pela a mizade que nos une.

\section{Obrigada}

...Ra ra s e especi a is sã o a s pessoa s que conjugam bondade e firmeza, dedicação a o trabalho e a mor à todos. 


\section{À CRI ANÇA,}

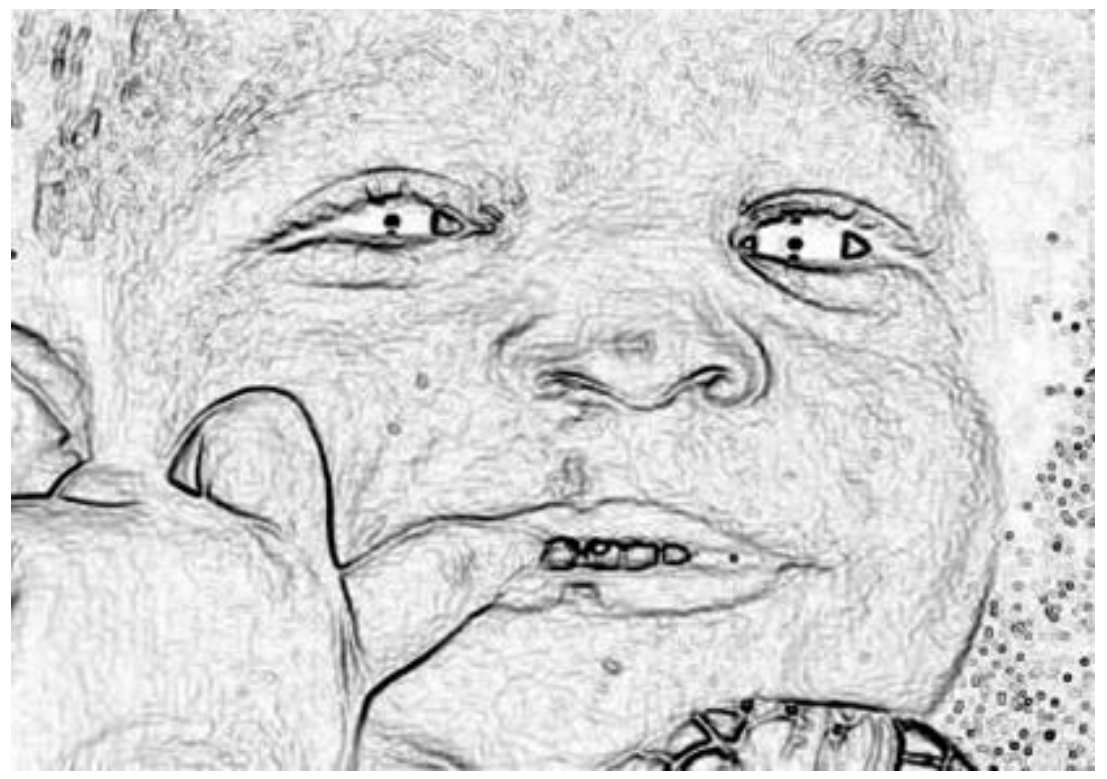

pelo sorriso, carinho e gestos

retribuíd os à quel es que se

dedicam à Odontopediatria 


\section{AGRADECI MENTOS}

Ao Hospital de Reabilitação de Anomalias Craniofaciais

Atra vés de seu Superin ten den te

Prof. Dr. J osé Alberto de Souza Freitas,

agradeço a oportunidade de compartilhar

de seu ideal de fazer sorrir, falar, ver, ouvir, sentir e integrar

Ao Diretor da Divis̃o Odontológica ,

Prof. Dr. Heli Benedito Brosco,

pela possibilidade de a primoramento profissional

Ao Di retor do Serviço Odontológico,

Prof. Dr. J oão Hen rique Nogueira Pinto,

pelo a poio e amizade

Ao presidente da Unidade de Ensino e Pesquisa, Prof. Dr. Leopoldino Capelloza Filho, pelo exemplo e estímulo á pesquisa 


\section{AGRADECI MENTOS}

\section{À Faculdade de Odontologia de Ba uru,}

a tra vés de seu Diretor Prof. Dr. Aymar Pavarini,

pelo constante incen tivo e a mizade

À Comissão dos Cursos de Pós-Graduação, a tra vés de seu Presi dente Prof. Dr. Luiz Fernando Pegoraro, pelo a poio no decorrer do curso 


\section{Meus a gradecimentos}

À todos os Professores do Curso de PósGraduação, pelos en si na men tos tra nsmitidos

Aos Professores do Departamento de Odontopediatria da FOB:

Dr. Vono, Dr. Aymar, Dra. Maria Francisca, Dr. José Eduardo, Dr. Ruy, Dra ${ }^{a}$. Salete e Dra. Maria Aparecida, pela oportunidade de poder desfrutar de seus conhecimentos, experiências e a mizade

Aos Funcionários do Departamento de Odontopediatria da FOB, Da Wilma, Da Lia, Maria Estela, Liliam, Fátima, Sr. Walter e Paulo, pelo convívio, a mizade e di sposi ção

Aos amigos do Curso de Pós-Graduação em Odontopediatria:

Cadu, Max, Nildinha e Valéria, por todos os caminhos que juntos andamos 


\section{AGRADECI MENTOS ESPECI AI S}

À Prof.". Dra. Marcia Ribeiro Gomide, pelo incentivo e confia nça no meu desenvolvimento. Poder desfrutar de sua amizade e a poio no mesmo ambiente de trabalho é motivo de muito orgulho para mim

Às Odontopediatras do HRAC: Cleide e Lucimara pelo ca rinho e a mizade que sempre nos uniu

Às demais funcionárias do Setor de Odontopediatria do HRAC, Claudia e Ana Maria, companheiras de todas a h oras e Alunos do Curso de Especialização, minha gratidão pela convivên cia a gradá vel e a poio indispen sá veis no dia a dia de trabalho

Ao Prof. Dr. Sérgio Aparecido Torres e Funcionários do

Departamento de Microbiologia da FOB: Dalva, Sr. Osni e André, agradeço por terem participado comigo, como uma família, em todas as etapas da realização deste trabalho, colaborando para meu crescimento pessoal e intelectual. 


\section{AGRADECI MENTOS}

Aos Funcionários da Unidade de Ensino e Pesquisa do Hospital de Reabilitação de Anomalias Craniofaciais, pela amizade, cola bora ção e disponibilida de con stantes

Aos Funcionários do Serviço de Biblioteca e Documentação da Faculdade de Odontologia de Bauru, em especial à Cibele pela presteza e a mizade

Aos Funcionários da Secretaria de Pós-Graduação, da Faculdade de Odontologia de Bauru, pela boa vontade constante

Aos Funcionários do Serviço de Prontuário de Pacientes e da Central de Agendamento do HRAC pela valiosa colabora ção na realização deste trabalho 


\section{Meu profundo agradecimento}

Às gra nd es e etern a s a miza des: TERESA, SUELI E MARCI NHA

Ao José Roberto Pereira Lauris pela realização da Análise Esta tística

À Dalva, a miga e sempre disposta a ajudar

À Gisele, possuidora de tantos dons, sempre compartilhados

Ao Setor de Fotografia do HRAC, Toninho, Carlos e Edson, e à

Teka pela realização das fotografias

Aos Pacientes do HRAC, razão mai or do nosso a primoramen to

En fim, à todos aqueles que de alguma forma contribuíram para a realização deste tra balho. 
SUMÁRIO

RESUMO

01 INTRODUÇÂO 02

02 REVISÃO DE LITERATURA 07

I - Doença periodontal em portadores de fissura 07

II - Gengivite e microbiota periodontal em crianças 25

03 PROPOSIÇÃO $\quad 69$

04 MATERIAL E MÉTODOS 71

05 RESUltados 86

06 DISCUSSÃO 102

07 CONCLUSÕES 132

$\begin{array}{ll}\text { ANEXOS } & 135\end{array}$

REFERÊNCIAS BIBLIOGRÁFICAS 147

$\begin{array}{ll}\text { ABSTRACT } & 169\end{array}$ 
Resumo 


\section{RESUMO}

Crianças portadoras de fissura de lábio e palato apresentam alterações anatômicas decorrentes da própria anomalia e dos procedimentos terapêuticos para a sua reabilitação, que podem predispô-las a um maior acúmulo de placa bacteriana, principalmente na região anterior da maxila. Com o objetivo de comparar as condições clínicas, através da utilização dos índices de placa (IP) e gengival (IG) de Löe (1967) e a presença das bactérias $P$. gingivalis, $P$. nigrescens e $T$. denticola, através da técnica "Slot Immunoblot", foram avaliadas 57 crianças com dentição decídua e idades entre 5 e 6 anos, sendo 30 portadoras de fissura completa de lábio e palato unilateral (grupo experimental) e 27 crianças sem fissura (grupo controle). O IP médio do grupo experimental $(1,82 \pm 0,38)$ foi superior ao do grupo controle $(1,63 \pm 0,38)$, embora sem diferença estatisticamente significante, enquanto o IG médio do grupo experimental $(1,05 \pm$ $0,22)$ foi significantemente superior ao do grupo controle $(0,79 \pm 0,33)(p<0,05)$. No grupo experimental a área da fissura (2 sítios), com IP médio de 2,04 $\pm 0,58$ e IG médio de $1,11 \pm 0,26$, quando comparada à região posterior (4 sítios), com IP médio de 1,74 $\pm 0,37$ e IG médio de $1,04 \pm 0,26$, mostrou diferença estatisticamente significante somente em relação ao IP. Considerando a severidade, a maioria das crianças dos dois grupos apresentou IP de grau moderado, $73,33 \%$ para o grupo experimental e $81,48 \%$ para o grupo controle; enquanto, para o IG, a maioria apresentou severidade de grau baixo, sendo de $53,33 \%$ para o grupo experimental e de 70,37\% para o grupo controle. Quando da 
estatisticamente significante somente em relação ao IP, que foi maior na área da fissura. Na pesquisa dos microrganismos a $P$. nigrescens foi detectada com prevalências de $16,67 \%$ no grupo experimental e de $11,11 \%$ no grupo controle, enquanto a $P$. gingivalis e o $T$. denticola não foram detectados. As crianças portadoras de fissura completa de lábio palato unilateral apresentaram maior inflamação gengival frente ao mesmo acúmulo de placa e a mesma prevalência dos microrganismos pesquisados, quando comparadas às do grupo controle. 
1 Introdução 


\section{INTRODUÇÃO}

As bactérias iniciam a colonização da cavidade bucal desde o nascimento e seguem colonizando os tecidos moles, incluindo a gengiva, bochechas e língua, e os dentes, tanto acima como abaixo da margem gengival, no que se conhece como a microbiota normal ou indígena, até a morte do indivíduo. Calcula-se que entre 300 e 400 espécies são capazes de colonizar a boca e que qualquer indivíduo pode abrigar de 150 a 200 espécies diferentes.

Na década de 60, o estudo clássico de LÖE; THEILADE; JENSEN ${ }^{51}$ (1965) demonstrou que o acúmulo de placa precedia diretamente e iniciava a gengivite, mas demorou um tanto para modificar-se o conceito de que a composição da placa era relativamente semelhante de paciente para paciente, de sítio para sítio no mesmo paciente, ou de sítio sadio para sítios com diferentes formas clínicas de doença periodontal. Hoje, o conceito vigente é o de que existem diferenças nítidas na microbiota subgengival na saúde e na doença.

Assim, a periodontite do adulto, por exemplo, pode representar uma série de infecções em que vários patógenos aparecem como candidatos: P.gingivalis, P.intermedia, B.forsythus, P.micros, A.actinomycetemcomitans, W.recta, E.timidum, F.nucleatum ou combinações desses microrganismos $22,34,66,95,106$. Em formas severas de periodontite, o principal envolvido tem sido a $P$.gingivalis ${ }^{85}$, 94, 95, 117, 122, 126. Também têm sido associadas com a periodontite progressiva do adulto, outras espécies como, o T.denticola, Selenomonas noxia e várias espécies de Eubacterium ${ }^{96}$. 
Os microrganismos a serem pesquisados neste trabalho, Porphyromonas gingivalis, Prevotella intermedia/nigrescens e Treponema denticola são considerados importantes periodontopatógenos potenciais, tanto quando se utilizam os critérios de SOCRANSKY ${ }^{97}$ de associação, eliminação, resposta do hospedeiro, patogenicidade animal, produção de mediadores potencialmente patogênicos, como quando se pesquisam os atributos sugeridos por SLOTS; GENCO $^{95}$ quais sejam, a capacidade para se implantar no sulco gengival, produzir substâncias direta ou indiretamente envolvidas na destruição periodontal, invadir os tecidos e escapar dos mecanismos de defesa do hospedeiro. Isso significa dizer que a sua presença, agindo sós ou como uma infecção mista com outras bactérias, e possivelmente, em concomitância com a ausência de espécies benéficas e a presença de certas deficiências imunológicas no hospedeiro seja essencial para a atividade da doença ${ }^{33,98 .}$

No quadro atual, portanto, a placa é considerada como fator determinante para o desenvolvimento da doença periodontal, com alguns microrganismos se destacando como periodontopatógenos potenciais, por preencherem os critérios de Socransky, apesar da dificuldade para determinar qual dos prováveis candidatos é o microrganismo crítico em determinado sítio ou indivíduo. Há muitas questões a serem ainda investigadas, como o momento da colonização pelos periodontopatógenos e a influência de fatores locais e sistêmicos sobre eles; a fonte e os mecanismos de transmissibilidade desses microrganismos; as relações ecológicas entre espécies bacterianas, cuja investigação pode definir as interações bacterianas críticas. 
Com o surgimento de novas técnicas e métodos refinados de identificação das espécies de muitos microrganismos, tornou-se necessário reavaliar a freqüência de microrganismos específicos em diferentes idades e populações, não só porque isso pode definir a população microbiana essencialmente não patogênica para iniciar a doença periodontal ${ }^{25}$, como também o momento de colonização inicial de microrganismos periodontopáticos ${ }^{124}$.

Em trabalho realizado por $\mathrm{ROSA}^{82}$, em 1995, utilizando a técnica do "slot immunoblot", foram pesquisadas dez bactérias, entre elas os periodontopatógenos que serão avaliados neste estudo, em amostras de placa subgengivais de 59 crianças brasileiras com idades entre 3 e 6 anos, sendo detectada apenas a $P$. intermedia em $23,7 \%$ das mesmas, com baixa intensidade de colonização, enquanto que a $P$. gingivalis e $0 T$. denticola não foram encontrados.

O início e a progressão das infecções periodontais são claramente modificados por condições locais e sistêmicas, denominadas fatores de risco. Dentre os principais fatores de risco sistêmicos estão a diabetes mellitus não controlada e o fumo, que afetam significantemente o início e a progressão da doença periodontal em adultos e, além disso, as condições sistêmicas associadas com número reduzido de neutrófilos também são importantes em crianças, adolescentes e adultos jovens. Os fatores de risco locais estão relacionados às situações anatômicas individuais que, de alguma maneira, favorecem a deposição de placa bacteriana por propiciarem condições de retenção, como restaurações defeituosas, respiração bucal, mal posicionamento dentário, aparelhos ortodônticos e protéticos $^{28}$. 
Os pacientes portadores de fissura completa de lábio e palato apresentam vários fatores de risco locais decorrentes dos desvios anatômicos da malformação (mal posicionamentos dos dentes e segmentos maxilares, respiração bucal em decorrência de desvio do septo nasal ou estenose narinária) e das intervenções terapêuticas necessárias para sua reabilitação (fibrose cicatricial labial resultante do seu reparo cirúrgico, utilização de aparelhos ortodônticos e próteses) que podem favorecer o acúmulo de placa bacteriana e serem considerados fatores agravantes para a doença periodontal, principalmente na região anterior da maxila $11,12,13,14,20,27,75,79,87,108$

Considerando o complexo e extenso processo reabilitador a que estes pacientes são submetidos, devem ser empreendidos esforços para que sejam precocemente estabelecidas, estratégias que minimizem os riscos às doenças bucais e, entre estas, estão a melhoria da higiene bucal e o conhecimento da microbiota subgengival de crianças portadoras de fissura.

Uma vez que a literatura nacional inexiste sobre este assunto e a literatura mundial apresenta poucos estudos de avaliação clínica em crianças portadoras de fissura $11,20,75,111$, sendo que o único estudo microbiológico sobre placa subgengival foi realizado em adultos ${ }^{64}$, é preciso verificar se essas crianças, face ao defeito local, podem ser colonizadas mais precocemente por microrganismos periodontopatógenos que poderiam predispô-las, no futuro, às doenças periodontais. 
2 Revisão de Literatura 


\section{REVISÃO DE LITERATURA}

\section{I - Doença periodontal em portadores de fissura}

Os trabalhos disponíveis sobre o estado da saúde periodontal de portadores de fissura, em alguns casos, analisaram amostras heterogêneas agrupando diferentes tipos de fissura. Tais tipos constituem, de certa forma, patologias individuais, uma vez que envolvem estruturas anatômicas distintas. Portanto, para facilitar o entendimento do significado dos resultados obtidos nessas pesquisas, torna-se necessária uma breve explanação sobre o assunto.

No Hospital de Reabilitação de Anomalias Craniofaciais (HRAC) em Bauru, São Paulo, utiliza-se a classificação de SPINA et al. ${ }^{102}$ que se baseia em um ponto de referência anatômico, o forame incisivo, para dividir as fissuras basicamente em 4 grupos:

- Fissuras pré-forame incisivo

- Fissuras pós-forame incisivo

- Fissuras transforame incisivo

- Fissuras raras da face

Esta classificação é de simples entendimento e facilita a comunicação entre os membros da equipe multidisciplinar para o tratamento de fissuras. 
$\mathrm{Na}$ literatura mundial os tipos de fissura são geralmente descritos de acordo com as estruturas anatômicas envolvidas. Tem-se assim:

- As fissuras de lábio e as fissuras de lábio e alvéolo, que podem ser unilaterais ou bilaterais, incompletas ou completas. Na fissura labial pode haver envolvimento parcial ou completo do lábio. As fissuras de lábio e alvéolo incompletas podem afetar parcialmente o rebordo alveolar sem contudo, provocar sua ruptura. Quando completas, vêm acompanhadas de fissura do rebordo alveolar, atingindo o forame incisivo e provocando divisão da maxila, em sua porção anterior, em dois segmentos. Neste grupo de fissuras existe envolvimento estético, pois a fissura labial é aparente, mas ausência de problemas funcionais como o de fala, uma vez que não afeta o palato. As fissuras de lábio e as de lábio e alvéolo podem vir acompanhadas, na região do defeito, de alterações dentárias de forma, estrutura, número e posição que podem predispor seus portadores a um maior risco à cárie e à doença periodontal (FIGURA 1). 

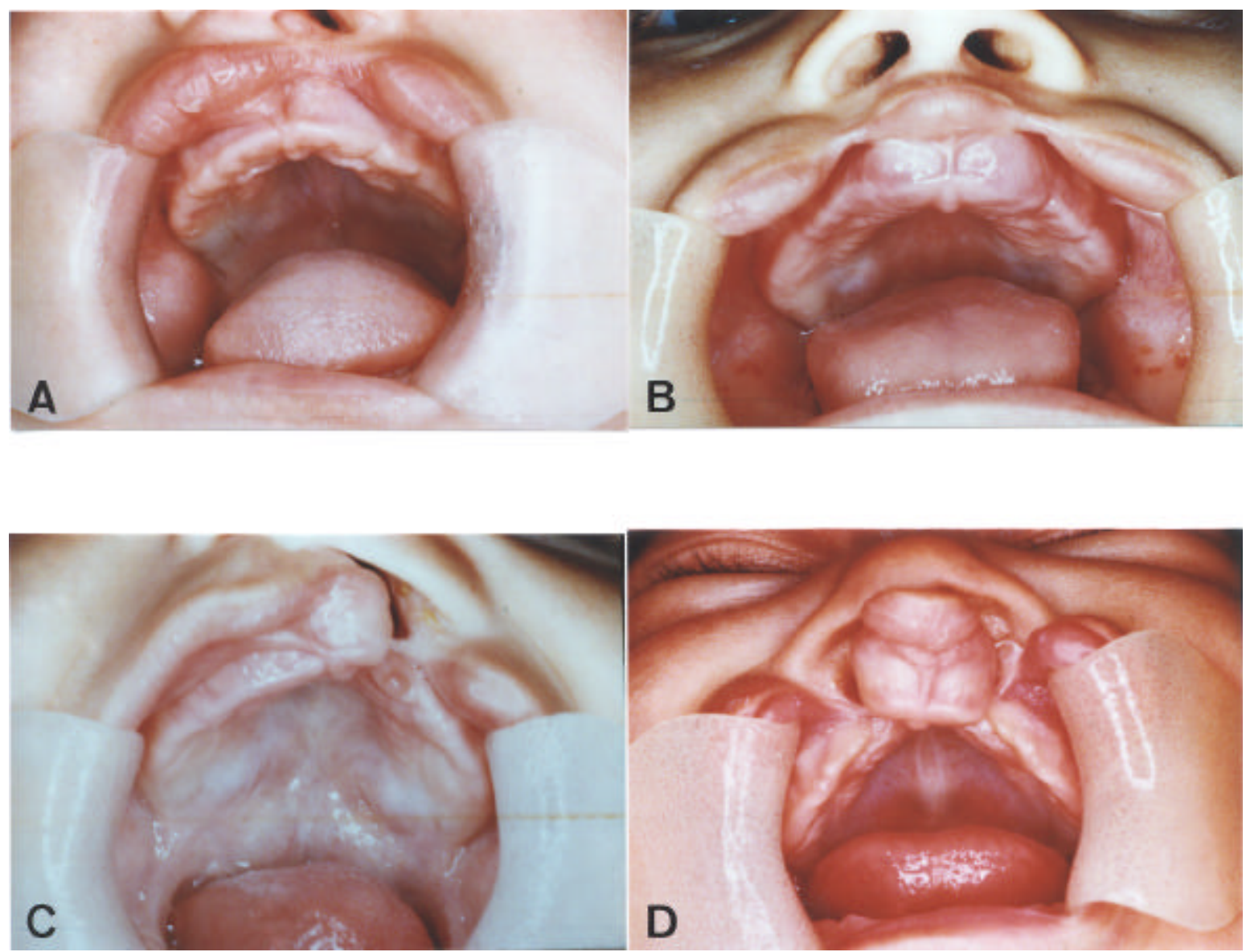

FIGURA 1 - Fissura de lábio incompleta (A - unilateral e B - bilateral) e Fissura de lábio e alvéolo completa (C - unilateral e D - bilateral) 
- As fissuras de palato, que podem ser completas ou incompletas. Neste caso, a integridade do lábio e rebordo alveolar é mantida, acometendo somente o palato em diversos graus de extensão, desde o envolvimento parcial da úvula até a divisão completa do palato (úvula, palato mole e palato duro até atingir o forame incisivo). Não existe comprometimento estético ou alterações alveolares e dentárias decorrentes deste tipo de fissura; no entanto, são comuns problemas funcionais, principalmente fonoaudiológicos, com prejuízo da inteligibilidade de fala (FIGURA 2).

- As fissuras completas de lábio e palato, que podem ser unilaterais ou bilaterais. Este tipo de fissura é o mais grave, dividindo a maxila totalmente em 2 segmentos, quando unilateral e em 3 segmentos, quando bilateral. Existe ruptura completa, envolvendo desde a úvula, palato mole, palato duro, rebordo alveolar até o lábio, provocando alterações estéticas e funcionais, mesmo após a terapia cirúrgica reparadora. Os problemas dentários, como alterações de forma, estrutura, número e posição, são freqüentes na região da fissura, assim como o colapso dos segmentos maxilares levando a mordidas cruzadas ou mesmo atresias maxilares, decorrentes da própria fissura e das tensões cicatriciais provocadas pelos procedimentos cirúrgicos reparadores. As alterações dentárias somadas às cicatrizes cirúrgicas constituem fatores de risco muito maior à cárie dentária e à doença periodontal (FIGURA 3). 


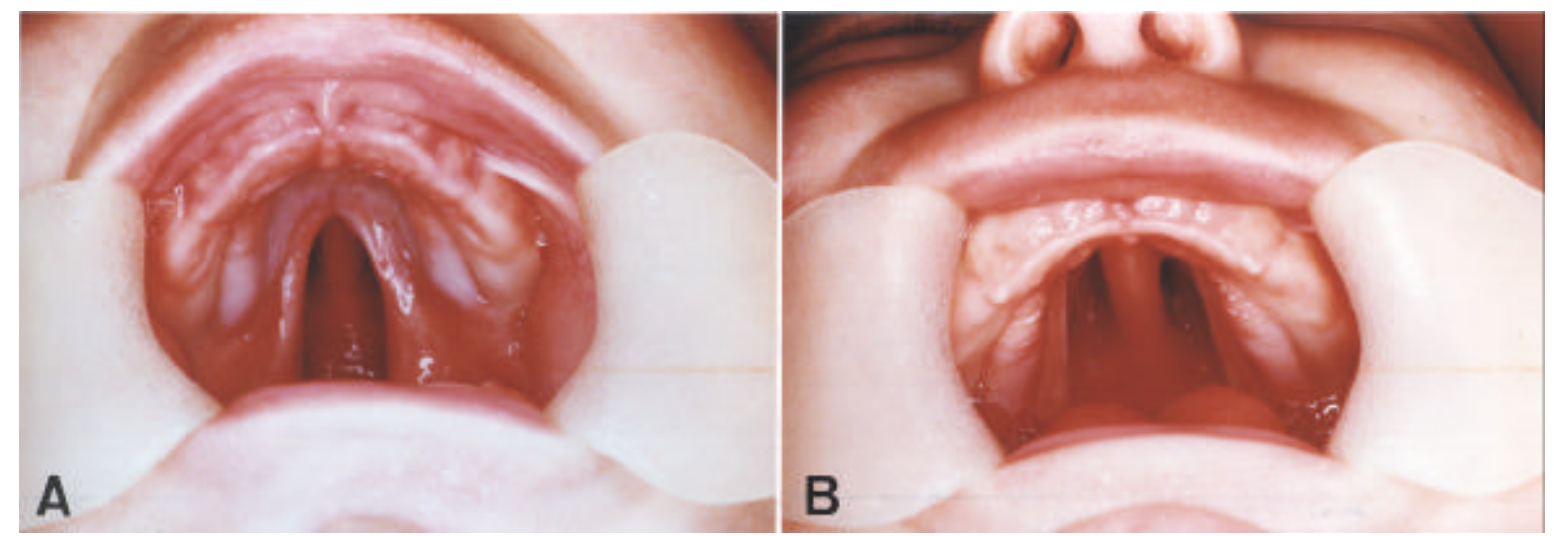

FIGURA 2 - Fissura de palato (A - incompleta e B - completa).
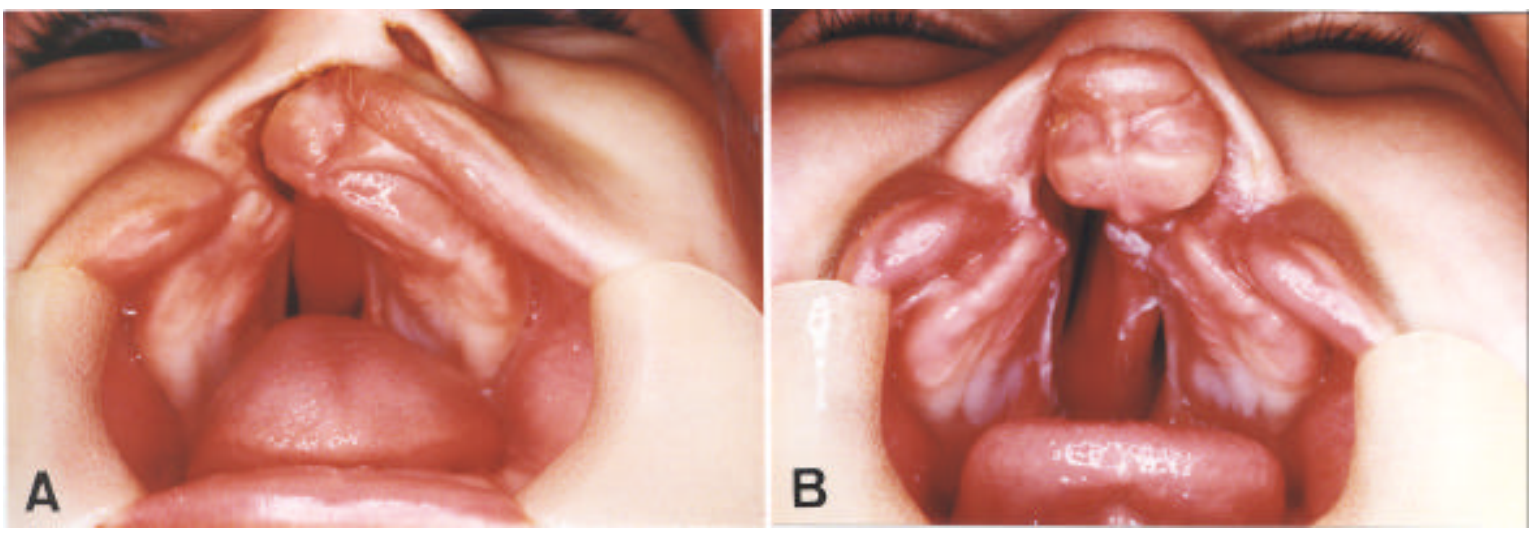

FIGURA 3 - Fissura completa de lábio e palato (A - unilateral e B bilateral). 
Em 1985, BRÄGGER et al. ${ }^{12}$ investigaram os hábitos de higiene bucal e as condições periodontais de um grupo de 80 pacientes adultos, com idades entre 1820 anos, portadores de fissura de lábio e/ou palato, ao final de um tratamento longitudinal multidisciplinar de 18 anos na Universidade de Berne, na Suíça. Foram registrados os índices de placa, de cálculo e de sangramento gengival, profundidade de bolsa, perda de inserção, envolvimento da furca e determinada a altura da crista óssea alveolar à junção amelo-cementária. Não houve diferenças estatisticamente significantes entre os vários tipos de fissura para todos parâmetros clínicos avaliados, exceto para as médias de profundidade de bolsa por lingual e vestibular, que foram mais rasas no grupo de fissura isolada de lábio. Nos pacientes portadores de fissura completa de lábio e palato $(n=29)$ a porcentagem de superfícies dentárias cobertas com placa foi alta $(69,9 \%)$ enquanto que o índice de sangramento gengival ocorreu em $73,5 \%$ dos sítios sondados. Quando a profundidade de bolsa e a perda de inserção nos sítios adjacentes à fissura alveolar foram comparadas às dos dois sítios controles não afetados, não foram encontradas diferenças estatisticamente significantes; todavia, na comparação radiográfica, a altura óssea por eles exibida foi significantemente menor. Estes resultados podem indicar a presença de um tecido conjuntivo de inserção extenso, sem suporte ósseo na região da fissura. Como resultado de uma higiene bucal inadequada, os pacientes com fissura completa de lábio e palato apresentaram periodontite inicial com perda de inserção e início de envolvimento de furca, na maioria dos casos. Os autores sugerem que uma vez que estes pacientes necessitam de uma terapia ortodôntica a longo-prazo, com aparelhos 
fixos, devem ser incluídos em programas de profilaxia intensivos, tão precocemente quanto possível.

Um dos poucos trabalhos com crianças fissuradas foi realizado por DAHLLÖF et al. ${ }^{20}$, em 1989, que avaliaram a saúde bucal de 49 crianças com idades entre 5 e 6 anos portadoras de fissura de lábio e/ou palato e de 49 crianças não fissuradas, pareadas por sexo e idade. Para a avaliação da cárie dentária, os procedimentos experimentais incluíram o exame clínico e radiográfico, coleta de amostra de saliva e entrevista com os pais sobre hábitos de higiene bucal e dieta. A condição gengival foi estimada de acordo com o índice de sangramento gengival. Os resultados mostraram aumento estatisticamente significante na prevalência e atividade de cárie em crianças com fissura de lábio e/ou palato. O número médio de superfícies cariadas e restauradas no grupo de crianças fissuradas foi de 7,0 comparado com 3,9 no grupo controle $(p<0,05)$. Não houve diferenças significantes na prevalência e atividade de cárie em crianças com fissura que envolvia o alvéolo, comparadas com crianças com fissura isolada de lábio ou palato. As crianças portadoras de fissura de lábio e/ou palato também exibiram um aumento significante $(p<0,01)$ no número de unidades gengivais com gengivite sendo a diferença ainda maior quando avaliadas somente as unidades da região anterior superior, incluindo a área da fissura. Estes resultados indicam que crianças portadoras de fissura de lábio e/ou palato devem ser consideradas um 
grupo com aumento do risco à cárie e gengivite e, portanto, incluídas em programas preventivos adicionais.

$\mathrm{Na}$ tentativa de revelar os efeitos da própria fissura ou de seu tratamento sobre as condições periodontais de dentes adjacentes à mesma, RAMSTAD ${ }^{79}$, em 1989, examinou 50 adultos portadores de fissura completa de lábio e palato unilateral, com idades entre 17,8-23,8 anos. Estes indivíduos haviam recebido tratamento especializado do nascimento até a idade adulta, com instalação de prótese fixa na área da fissura. No exame periodontal dos dentes de suporte da prótese e dos outros dentes da maxila avaliou o acúmulo de placa, sangramento gengival e profundidade de sondagem de bolsa, tendo verificado pior condição periodontal nos dentes de suporte das próteses, um dado consistente com as observações na população geral. Para o autor, os efeitos adversos do tratamento protético, mais do que a variação anatômica criada pelo reparo da fissura, foram a causa da saúde periodontal mais precária nesta região.

BRÄGGER et al. ${ }^{13}$, em 1990, examinaram as condições periodontais de pacientes adultos (faixa etária de 26-28 anos), sendo 19 portadores de fissura completa de lábio e palato unilateral e 6 com fissura completa de lábio e palato bilateral, passados oito anos da última avaliação, período durante o qual não foram submetidos a programas de manutenção supervisionados profissionalmente sendo 
considerados, portanto, de maior risco à doença periodontal. Foram observados um grande acúmulo de placa (de $62 \%$ à $71 \%$ ) e alta freqüência de unidades gengivais com inflamação (entre $62,5 \%$ e $73,8 \%$ ) na maioria dos pacientes, demonstrando padrões inadequados de higiene bucal. Os autores não encontraram maior destruição periodontal nos sítios fissurados, que apresentaram um tecido conjuntivo de inserção extenso, quando comparados aos sítios controles, concluindo que estes sítios, não parecem ser mais predispostos à doença periodontal induzida por infecção bacteriana, do que aqueles com altura normal da inserção fibrosa supra-alveolar e que, portanto, o exame radiográfico tem valor limitado para o diagnóstico do grau de destruição periodontal nos sítios com defeitos alveolares.

Os mesmos autores ${ }^{14}$, em 1992, publicaram outro trabalho sobre a taxa de progressão da doença periodontal, durante um período do 8 anos, em um grupo de 52 pacientes adultos (faixa etária de 26-28 anos), portadores de vários tipos de fissura de lábio, alvéolo e palato, que não haviam sido submetidos à terapia de suporte freqüente. De especial interesse foi a avaliação de alterações nos sítios adjacentes à fissura comparadas àquelas observadas nos sítios controles do mesmo paciente, através da análise de parâmetros clínicos como índice de placa, cálculo, sangramento gengival na sondagem e profundidade de bolsa periodontal. Durante o período avaliado, os pacientes foram tratados com prótese fixa e exibiram higiene bucal deficiente e inflamação gengival, as quais já estavam 
presentes no início do estudo, além de perda de inserção e de osso alveolar, com o exame radiográfico mostrando altura óssea significantemente menor nos sítios adjacentes à fissura. $\mathrm{O}$ estudo conclui que a abordagem de uma equipe coordenada para o tratamento de todos aspectos das fissuras de lábio e/ou palato deve incluir supervisão freqüente e motivação das medidas de higiene bucal, por toda a vida do paciente.

Frente à dúvida sobre a causa da maior prevalência de doença periodontal em portadores de fissura decorrer de fatores de risco microbiológicos específicos ou de uma higiene bucal deficiente com presença contínua de grande quantidade de placa bacteriana não específica, MOMBELLI; BRÄGGER; LANG ${ }^{64}$, em 1992, procuraram caracterizar a microbiota isolada da fissura residual e de sítios periodontais de dentes adjacentes ao defeito e relacionar a presença de periodontopatógenos presumíveis no defeito da fissura à composição microbiana da placa subgengival do dente adjacente. Investigaram também a influência da manutenção regular nos parâmetros clínicos (índice de placa e índice de sangramento gengival) e microbiológicos da região da fissura. Para isto, avaliaram 20 pacientes, com idades entre 20 e 45 anos, com fissura completa de lábio e palato uni ou bilateral, apresentando fissura residual no rebordo alveolar ou fissuras pronunciadas nos tecidos moles, que haviam sido submetidos a tratamento reabilitador extenso na área da fissura até alguns anos antes. Destes, 10 pacientes receberam profilaxias dentárias a intervalos regulares (em média a cada 
seis meses) e os outros 10 não, após a conclusão do tratamento reabilitador. Depois do registro dos índices de placa e gengival, dos sítios escolhidos foram coletadas amostras de placa subgengival para o cultivo, do sulco voltado para o defeito (T1) e da superfície oposta (T2) e da fissura residual ou sulco tecidual (F). Além da cultura para vários microrganismos, foi realizado também o exame por microscopia em campo escuro. Os indivíduos submetidos à manutenção regular apresentaram índices de placa significantemente menores nos sítios dentários adjacentes à fissura. A freqüência de sangramento gengival durante a amostragem foi significantemente maior no grupo sem manutenção, nas superfícies dentárias opostas à fissura. Não foram observadas diferenças em relação aos microrganismos anaeróbios Gram negativos entre os dois grupos. Os microrganismos Fusobacterium spp., Prevotella melaninogenica e $P$. intermedia apareceram com maior freqüência no grupo de pacientes que não receberam profilaxia periódica. Os espiroquetas e bacilos móveis raramente foram observados no grupo que realizou profilaxia, sendo comuns no outro grupo. A microbiota encontrada na área da fissura mostrou-se mais simples que a dos sítios subgengivais e lembrava a microbiota subgengival dos dentes de pacientes bem mantidos, independentemente da qualidade da manutenção. A microbiota de T1 e T2 não diferiu significantemente entre si. $\mathrm{O}$ Actinobacillus actinomycetemicomitans e a Porphyromonas gingivalis não foram encontrados em nenhuma das amostras, enquanto a Prevotella intermedia foi encontrada nos três sítios em ambos os grupos. Os espiroquetas raramente foram detectados na região das fissuras: apenas em 1 paciente de cada grupo, mas foram comuns no 
grupo que não recebeu tratamento de manutenção regular (7/10 em T1 e 3/10 em T2) e praticamente ausentes no outro grupo (0/10 em T1 e 1/10 em T2). Os resultados clínicos e microbiológicos deste estudo enfatizaram a importância de retornos freqüentes para manutenção contínua, após o tratamento dentário extensivo em pacientes com fissura completa de lábio, alvéolo e palato.

Em 1992, TEJA; PERSSON; OMNELL ${ }^{108}$ compararam a condição periodontal de dentes adjacentes à fissura com dentes contralaterais em pacientes adultos (faixa etária de 19-45 anos) portadores de fissura completa de lábio e palato unilateral que não haviam sido submetidos a enxerto ósseo. Foram avaliados parâmetros periodontais em 18 indivíduos que apresentavam pelo menos um dente adjacente à fissura. Para cada dente investigado registraram-se o índice de placa, o índice gengival, a profundidade de sondagem, o grau de mobilidade, a largura da gengiva inserida, a extensão da recessão gengival e a altura do nível ósseo. Os resultados indicaram que o grau de higiene bucal foi pior do lado fissurado comparado ao não fissurado. Além disso, nos indivíduos com fissura alveolar que não receberam enxerto ósseo, os dentes adjacentes ao defeito mostraram somente sinais de gengivite, mas não de doença periodontal. Os autores sugeriram que o defeito anatômico, o padrão de erupção, movimentos dentários ortodônticos e a presença de restaurações contribuem para a redução do nível ósseo no incisivo central adjacente à fissura e para a presença de gengivite na faixa etária examinada. 
Em estudo comparativo, BOKHOUT et al. ${ }^{11}$ (1997) determinaram a prevalência de cárie, a condição gengival e a higiene bucal em 81 crianças holandesas portadoras de fissura de lábio e/ou palato e em 77 crianças sem malformação congênita, com idades entre 1,5-4 anos. A maioria das crianças foi examinada aos 2,5 anos e aos 4 anos. Na amostra total $48 \%$ das crianças pertenciam a um nível sócio-econômico alto, 51\% apresentaram boa higiene bucal e $61 \%$ não apresentaram inflamação gengival. As crianças portadoras de fissura apresentaram higiene bucal significantemente mais precária, mais inflamação gengival e pertenciam à classes sócio-econômicas menos favorecidas do que as crianças não fissuradas. A prevalência de cáries em crianças fissuradas foi 3,5 vezes mais alta do que nas crianças sem fissura, sendo predominantemente manifestada nos dentes adjacentes à fissura e em molares decíduos, neste grupo de pacientes. Este estudo mostra que crianças fissuradas são de maior risco à cárie dentária e portanto, seus pais devem ser precocemente submetidos a programas preventivos para a melhora da higiene bucal de seus filhos.

A avaliação do estado de saúde bucal e dentária de 114 crianças inglesas (na faixa etária de 3-18 anos), atendidas em duas clínicas para o tratamento de fissuras lábio-palatais foi realizada por PAUL; BRANDT ${ }^{75}$, em 1998, utilizando critérios e índices padronizados. Todos pacientes já haviam sido operados e foram 
divididos em três grupos, de acordo com as faixas etárias: dos 3 - 5 anos (36\%), 6 - 12 anos (43\%) e dos $13-18$ anos (21\%). Um total de $51,8 \%$ da amostra apresentava fissura completa de lábio e palato sendo $64,3 \%$ unilateral e $35,7 \%$ bilateral. Independentemente da faixa etária, o índice de placa foi maior no grupo de pacientes com fissura completa de lábio e palato. Combinando os grupos de fissura de lábio e alvéolo e fissura completa de lábio e palato, com base em sua similaridade morfológica, observaram associação estatisticamente significante entre o índice de higiene bucal médio deste grupo e aquele do grupo de fissura isolada de palato. Além disso, o acúmulo de placa foi significantemente maior no segmento anterior quando comparado ao dos posteriores e também maior no arco superior em relação ao inferior. Quando a média do índice gengival da combinação dos grupos com fissura de lábio e alvéolo e fissura completa de lábio e palato foi comparada com a do grupo com fissura de palato isolada houve diferença estatisticamente significante entre eles, sendo que as crianças com fissura isolada de palato apresentaram melhor saúde gengival. Houve também diferença significante quando os índices gengivais das regiões anterior e posterior foram comparados, não sendo notada diferença significante na comparação dos índices dos arcos superior e inferior. Os autores sugeriram que os estados precários de higiene bucal e saúde gengival encontrados neste grupo de pacientes, principalmente no segmento anterior, deveu-se ao acesso reduzido para limpeza dessa região após o reparo cirúrgico do lábio, sendo necessário, portanto, sua inclusão em programas preventivos. 
Com o propósito de verificar a saúde bucal de crianças russas que haviam sido submetidas à palatoplastia primária pela técnica de Frolova, TURNER et al. ${ }^{111}$, em 1998, avaliaram 89 crianças (62 meninos e 27 meninas, com idades entre 5 e 9 anos) portadoras de fissura completa de lábio e palato unilateral, registrando aspectos como estágio da dentição, higiene bucal, cárie, dentes ausentes e restaurados e o tipo de oclusão. Constataram que $30 \%$ das crianças apresentavam fístula no palato, sendo a higiene bucal de pacientes sem esta alteração significantemente melhor do que a dos pacientes com fístula $(p<0,01)$, e que $45 \%$ exibiam um ou mais dentes cariados. Concluíram que as altas porcentagens de higiene bucal deficiente (66\% razoável ou pobre) e de cárie dentária observadas neste grupo de pacientes decorreram provavelmente da indisponibilidade de produtos de higiene dentária e do seu alto custo, quando disponíveis. Além disso, observaram que os pais apresentaram entendimento limitado sobre a importância de procedimentos de higiene e da dieta adequada para a prevenção da cárie dentária.

Uma vez que os objetivos do tratamento de pacientes com fissuras bucofaciais são a saúde do sistema estomatognático a longo prazo, bem como a recuperação estética, SCHULTES; GAGGL; KÄRCHER ${ }^{87}$, em 1999, procuraram comparar a condição periodontal de 30 pacientes portadores de fissura completa de lábio e palato unilateral com a de 30 pacientes portadores de fissura isolada de 
palato, com idades entre 17-24 anos, para verificar a influência da fissura na saúde periodontal. As lesões periodontais foram classificadas de acordo com as necessidades de tratamento do Índice Periodontal da Comunidade (CPITN) sendo identificada a mobilidade patológica dos dentes. O estado da higiene bucal foi registrado pelo índice de placa interproximal. De modo geral, todos os pacientes apresentaram higiene bucal deficiente. Os pacientes com fissura completa de lábio e palato tiveram índice de placa com escore 0 em $0 \%$ dos casos, escores 1 e 2 em $7 \%$, escore 3 em $43 \%$ e 4 em $50 \%$ dos casos. Os pacientes portadores de fissura isolada de palato apresentaram escore 0 em $0 \%$, escores 1 e 2 em $30 \%$, escore 3 em $45 \%$ e escore 4 em 25\% dos casos. A doença periodontal em pacientes portadores de fissura isolada de palato exibiu extensão similar à da população geral, enquanto que nos pacientes com fissuras completas unilaterais observou-se uma predisposição à destruição periodontal profunda no dente adjacente à fissura. $\mathrm{O}$ registro da mobilidade patológica do dente e a resultante perda de inserção corresponderam à classificação de doença periodontal de acordo com o CPITN. Os autores concluíram que os pacientes com fissura completa unilateral apresentavam uma situação periodontal crítica, principalmente na região anterior da maxila, o que pode levar a perda prematura de dentes em uma área esteticamente importante. Ao contrário, os pacientes com fissura isolada de palato exibiram situação periodontal similar à encontrada na população geral, com alguns danos que podem ser atribuídos ao tratamento ortodôntico. 
Para complementar este estudo GAGGL et al. ${ }^{27}$, também em 1999, ao incluir um terceiro tipo de fissura, as fissuras completas de lábio e palato bilaterais, confirmaram que a condição periodontal dos portadores de fissura de palato isolada era semelhante à da população geral, com danos adicionais atribuídos ao tratamento ortodôntico. Demonstraram ainda que os 50 pacientes portadores de fissura completa de lábio e palato, tanto uni (30) como bilaterais (20), com idades entre 17-24 anos, apresentaram maior predisposição à destruição periodontal profunda, principalmente no dente adjacente à fissura.

A FIGURA 4 retrata um resumo das características das amostras analisadas pelos diferentes pesquisadores, em termos de número de participantes, faixa etária, tipo de fissura e os parâmetros clínicos analisados. 
Revisão de literatura

FIGURA 4 - Estudos sobre a saúde bucal de adultos e crianças portadoras de fissura lábio-palatal (Quadro modificado de WONG; KING,1998 ${ }^{125}$ )

\begin{tabular}{|c|c|c|c|c|}
\hline \multirow[b]{2}{*}{ AUTOR } & \multicolumn{3}{|c|}{ AMOSTRA } & \multirow[b]{2}{*}{ PARÂMETROS AVALIADOS } \\
\hline & Tipo de fissura & $\mathbf{N}$ & Idade (anos) & \\
\hline Brägger et al. ${ }^{12}$ (1985) & Todas & 80 & $18-20$ & $\begin{array}{l}\text { Placa, cálculo, gengivite, profundidade de sondagem, } \\
\text { envolvimento de furca }\end{array}$ \\
\hline Dahllöf et al. $^{20}(1989)$ & Todas & 49 & $5-6$ & Gengivite, cárie \\
\hline Ramstad $^{79}$ (1989) & Uni ou Bilateral de lábio e palato & 50 & $17,8-23,8$ & Placa, gengivite, profundidade de sondagem \\
\hline Brägger et al. ${ }^{13}(1990)$ & Uni ou Bilateral de lábio e palato & 25 & $26-28$ & $\begin{array}{l}\text { Placa, gengivite, profundidade de sondagem, nível de } \\
\text { inserção, nível ósseo }\end{array}$ \\
\hline Brägger et al. ${ }^{14}$ (1992) & Todas & 52 & $26-28$ & $\begin{array}{c}\text { Placa, cálculo, gengivite, profundidade de sondagem, } \\
\text { nível de inserção, nível ósseo }\end{array}$ \\
\hline $\begin{array}{l}\text { Mombelli; Brägger; Lang }{ }^{64} \\
\text { (1992) }\end{array}$ & $\begin{array}{l}\text { Uni ou Bilateral de lábio e palato } \\
\text { (fissura residual) }\end{array}$ & 10 & $27-30$ & $\begin{array}{c}\text { Placa, cálculo, gengivite, profundidade de sondagem, } \\
\text { nível de inserção, amostra microbiológica }\end{array}$ \\
\hline $\begin{array}{c}\text { Teja; Persson; Omnell }{ }^{108} \\
\text { (1992) }\end{array}$ & $\begin{array}{c}\text { Unilateral } \\
\text { (sem enxerto) }\end{array}$ & 18 & $19-45$ & $\begin{array}{l}\text { Placa, gengivite, profundidade de sondagem, } \\
\text { mobilidade dentária, nível ósseo }\end{array}$ \\
\hline Bokhout et al. ${ }^{11}$ (1997) & Todas & 81 & $1,5-4$ & Placa, gengivite, cárie \\
\hline Paul; Brandt ${ }^{75}$ (1988) & Todas & 114 & 3-18 & Placa, gengivite, cárie \\
\hline Turner et al. ${ }^{111}(1998)$ & Unilateral de lábio e palato & 89 & $5-9$ & Placa, cárie \\
\hline $\begin{array}{c}\text { Schultes; Gaggl; Kärcher }{ }^{87} \\
\text { (1999) }\end{array}$ & $\begin{array}{l}\text { Unilateral de lábio e palato } \\
\text { e isolada de palato }\end{array}$ & 60 & $17-24$ & $\begin{array}{c}\text { Placa, cálculo, gengivite, profundidade de sondagem, } \\
\text { mobilidade dentária }\end{array}$ \\
\hline Gaggl et al ${ }^{27}(1999)$ & $\begin{array}{l}\text { Uni e bilateral de lábio e palato } \\
\text { e isolada de palato }\end{array}$ & 80 & $17-24$ & $\begin{array}{c}\text { Placa, cálculo, gengivite, profundidade de sondagem, } \\
\text { mobilidade dentária }\end{array}$ \\
\hline
\end{tabular}




\section{II - Gengivite e microbiota periodontal em crianças}

Uma das dificuldades para o estudioso da microbiota bucal acompanhar a literatura específica sobre a mesma é a alteração observada na nomenclatura das bactérias ao longo dos anos. A evolução das técnicas de identificação, que nos seus primórdios baseavam-se quase que exclusivamente na morfologia colonial e modelos de fermentação, sofisticou-se ao ponto da identificação basear-se nas análises dos ácidos nucléicos (conteúdo de bases guanina-citosina, homologia de DNA, e sequências de RNAr 16S), suplementadas com perfís das enzimas e ácidos graxos bacterianos, o que levou, em muitos casos, à novas designações de espécies, abolições de subspécies e até mesmo à novas denominações de gêneros para antigas bactérias. Esse problema é particularmente verdadeiro para os bacilos Gram negativos anaeróbios produtores de colônias negras, entre os quais estão dois dos microrganismos analisados neste trabalho, a $P$. gingivalis e a $P$. nigrescens ( $P$. intermedia).

Como o leitor pode não estar familiarizado com os nomes recebidos por esses microrganismos nos diferentes trabalhos, na FIGURA 5 é apresentada a evolução da taxonomia dos mesmos. O microrganismo descrito inicialmente como Bacterium melaninogenicus, na realidade representava um grupo de microrganismos hoje classificados em três gêneros e várias espécies. Mencione-se ainda, que as últimas 5 espécies caninas de Porphyromonas foram estabelecidas em 1994; que a Prevotella nigrescens foi separada da P.intermedia em 1992; que a Prevotella tannerae foi descrita em 1994, e que o Bacteroides macacae e 
Bacteroides levii provavelmente serão incluídos no gênero Porphyromonas num futuro próximo ${ }^{39}$.

Particularmente em relação a P.intermedia, foi observada heterogeneidade intraespécie em estudos inicialmente feitos por JOHNSON; HOLDEMAN ${ }^{38}$ que, com base na homologia do DNA encontraram dois grupos distintos para a bactéria (VPI 4197 e 8944), e por GMÜR; GUGGENHEIM ${ }^{30}$, que dividiram a P.intermedia em 3 sorogrupos (I, II e III). Em 1992, um estudo abrangente sobre hibridização DNA-DNA propôs sua classificação em duas genoespécies, P.intermedia e P.nigrescens ${ }^{89}$. As cepas-tipo para representar a P.intermedia e a P.nigrescens foram a ATCC 25611 e a ATCC 33563, respectivamente.

A detecção de isolados bacterianos anaeróbios, Gram negativos, pigmentados, moderadamente sacarolíticos, indol-positivos e bioquimicamente mais relacionados à Prevotella intermedia e P.nigrescens, mas não tipados como nenhuma delas, levou KÖNÖNEN et al. ${ }^{46}$ a inicialmente sugerir, e depois, a partir de resultados filogenéticos propor uma nova espécie dentro do gênero Prevotella, a P.pallens, cuja cepa-tipo é a NCTC $13042\left(=\right.$ AHN 10371 ${ }^{47}$. 


\section{Bacterium melaninogenicus}

(1921)

\section{Bacteroides melaninogenicus}

(1970)

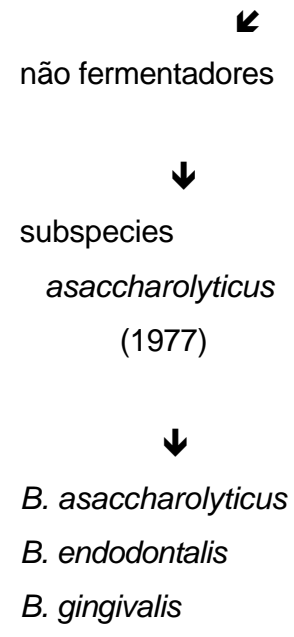

(1988)

Porphyromonas

P. asaccharolytica

P. endodontalis

$P$. gingivalis

P. salivosa

P. circumdentaria

P. canoris

$P$. cangingivalis

P. cansulci

P. crevioricanis

$P$. gingivicanis

B. macacae

B. levii

\section{B. intermedius}

B. corporis

(1990)

Prevotella

$$
\begin{aligned}
& \text { P. intermedia } \\
& \text { P. corporis } \\
& \text { P. nigrescens } \\
& \text { (P. pallens - 1998) }
\end{aligned}
$$

\section{ע}

fortes fermentadores

subespecies

melaninogenicus

(1977)

B. melaninogenicus

B. denticola

B. loescheii

(1990)

Prevotella
P. melaninogenica
P. denticola
P. loescheii
P. tannerae

FIGURA 5 - Evolução da taxonomia dos bacilos Gram-negativos anaeróbios formadores de colônias negras ${ }^{39,46,47}$. 
O outro microrganismo pesquisado neste trabalho foi o Treponema denticola, um espiroqueta. Os espiroquetas também representam um obstáculo na avaliação do seu significado para a doença periodontal, pela dificuldade em se distinguir espécies individuais. Pelo menos 15 espécies de espiroquetas subgengivais já foram descritas mas, na maioria dos estudos de amostras de placa, esses microrganismos são incluídos em um único grupo ou em grupos baseados no tamanho celular: pequeno, médio ou grande, o que obscurece o papel patogênico das diferentes espécies. $O$ não isolamento em meios de cultura de um grande número de espiroquetas, explica sua pesquisa através de exames a fresco, por alguns dos investigadores.

O primeiro estudo digno de nota sobre a microbiota da placa subgengival da dentição decídua foi feito em 1964 por ARAUJO; MACDONALD ${ }^{3}$, que investigaram amostras de crianças com idades entre 3 e 7 anos, sem gengivite e sem cárie. Nas amostras de 5 crianças, observaram que a proporção dos grupos cultiváveis predominantes (bacilos e cocos Gram positivos facultativos, cocos e bacilos Gram negativos anaeróbios e cocos Gram positivos anaeróbios) não diferiu daquela encontrada em adultos. Contudo, a pesquisa que fizeram em amostras de 15 crianças, através de cultura e da microscopia em campo escuro, para o $B$. melaninogenicus e para os espiroquetas revelou resultados diferentes dos encontrados em adultos: o primeiro foi detectado em 4, e os últimos, em 10 
crianças. Embora o número de indivíduos examinados tenha sido pequeno, os resultados sugeriram diferenças na microbiota subgengival de crianças com dentição decídua, quando comparada à dos adultos, uma vez que estudos anteriores demonstraram que estes microrganismos estavam regularmente presentes na boca e sulco gengival de adultos.

Para definir a idade de estabelecimento do $B$. melaninogenicus, considerado então o principal agente etiológico da doença periodontal, na microbiota subgengival durante a infância, BAILIT; BALDWIN; HUNT ${ }^{6}$, em 1964, pesquisaram-no em amostras raspadas do sulco gengival de dentes aleatoriamente selecionados, de 320 crianças com idades entre 5 e 15 anos, através do método de cultivo. Verificaram que o número de culturas positivas desse microrganismo aumentava com a idade, particularmente entre 7 e 9 anos. $\mathrm{Na}$ idade de 13 anos aproximadamente 100\% das culturas foram positivas, enquanto, na faixa etária de 5-7 anos somente $40 \%$ das crianças foram positivas. Não observaram diferenças em relação ao sexo. Para os autores, a prevalência crescente desse microrganismo poderia estar relacionada com possíveis exigências nutricionais do mesmo.

Em 1966, KELSTRUP ${ }^{40}$ examinou 35 crianças com idades entre 4 e 15 anos, detectando o B. melaninogenicus em $13 \%$ das amostras de crianças de 13 
a 15 anos de idade, mas em nenhuma criança entre 4 e 8 anos. A freqüência de isolamento do sulco gengival de periodonto normal e da gengivite foi a mesma.

Considerando que as pesquisas feitas até então baseavam-se em amostras pequenas e heterogêneas, MORHART et al. ${ }^{70}$ (1970) procuraram estudar o que ocorreria com a microbiota bucal de uma população homogênea, com os mesmos hábitos estabelecidos há centenas de anos, os índios maias da Guatemala. Foram avaliados 75 índios dos seguintes grupos etários: 4-6 anos, 7-9 anos e segunda, terceira, quarta, quinta e sexta décadas de vida, que tiveram as placas subgengivais de todos os dentes presentes, colhidas e semeadas para cultivo. No diagnóstico da saúde periodontal verificaram que a partir dos 4-6 anos já havia manifestação de gengivite marginal, ocorrendo um aumento progressivo da severidade da doença com a idade, sendo observada formação de bolsa periodontal verdadeira no grupo de 10-14 anos e perdas dentárias por volta dos 40 anos, pela progressão das alterações periodontais patológicas. As contagens bacterianas foram gerais: total de microrganismos, bacilos Gram negativos e bacilos Gram positivos, não sendo encontradas correlações entre a microbiota e os grupos etários ou a severidade da doença periodontal. Segundo os autores, a detecção de $B$. melaninogenicus na faixa etária dos 4-6 anos poderia ser conseqüência da grande quantidade de placa presente, que criaria condições para o fornecimento de nutrientes essenciais para esse microrganismo. 
Em pesquisa de gengivite experimental MACKLER; CRAWFORD ${ }^{53}$, em 1973, procuraram observar mudanças bacteriológicas no desenvolvimento da placa dentária de crianças em idade pré-escolar e explorar possíveis relações entre o desenvolvimento da placa e a gengivite, após um período de 26 dias sem escovação. Foram selecionadas 13 crianças caucasianas com idades entre 3 e 5,5 anos e seguidos dois protocolos: no primeiro, o estudo piloto, as amostras de placa foram analisadas apenas por exame de contraste de fase; no segundo, o estudo principal, além do contraste de fase foi feita a cultura para $\circ B$. melaninogenicus. Verificaram que o desenvolvimento morfológico da placa em crianças pré-escolares era similar ao observado em adultos; que os dentes inferiores acumularam mais placa do que os dentes superiores; que não houve diferença entre os dentes anteriores e posteriores em relação a quantidade total de placa acumulada e que, com a exceção de duas crianças que apresentaram gengivite marginal localizada, não ocorreu manifestação de gengivite marginal generalizada nas crianças. Qualitativamente, nas áreas inflamadas verificou-se uma placa complexa composta de filamentos, fusobactérias, vibriões e espirilos. Os espiroquetas foram observados na placa supragengival em 4 das 13 crianças avaliadas, na terceira semana após a suspensão da higiene bucal, enquanto que o B. melaninogenicus foi isolado de todas a crianças do estudo principal, pelo menos uma vez durante o experimento. 
Como estudos anteriores sugerissem que crianças e adultos diferiam na propensão para o desenvolvimento de gengivite quando da interrupção da higiene bucal, MATSSON ${ }^{56}$, em 1978, realizou um estudo comparativo entre 6 crianças pré-escolares (idades entre 4 e 5 anos) e 6 estudantes de Odontologia (idades entre 23 e 29 anos), sem cáries ou desordens sistêmicas, para confirmar a existência de tal diferença. Após um período de higiene bucal intensivo, a limpeza dos dentes foi interrompida por 21 dias. O grau de inflamação gengival foi determinado através da avaliação das quantidades de placa bacteriana, exsudato gengival, leucócitos do sulco gengival e tendência ao sangramento gengival, que foram registrados nos dias $0,7,14$ e 21. Durante o experimento a quantidade de placa bacteriana aumentou continuamente em ambos os grupos. A quantidade de exsudato gengival e a tendência ao sangramento gengival aumentaram marcadamente nos adultos e pouco nas crianças. A quantidade de leucócitos nos sulcos gengivais aumentou nos dois grupos, mas foi maior nos adultos. Para comparação da inflamação gengival foram consideradas as unidades dentárias que mostraram desenvolvimento de placa similares no último dia do experimento, sendo constatada maior tendência para o desenvolvimento de inflamação gengival nos adultos do que nas crianças, sob quantidades comparáveis de placa.

A prevalência e a distribuição intra-bucal dos Bacteroides negros bem como a correlação entre os achados microbiológicos e o estado clínico dos tecidos periodontais foram analisadas por ZAMBON; REYNOLDS; SLOTS ${ }^{126}$, em 1981 , 
que avaliaram 5 crianças com idades entre 3 e 5 anos com dentição decídua completa, 5 adultos com mínima inflamação gengival e 10 adultos com perda óssea alveolar moderada e severa. Para tanto, foram colhidas amostras de placa supra e subgengivais, superfície oclusal, língua, mucosa bucal, amígdalas e saliva. Os Bacteroides negros foram encontrados em $90 \%$ dos pacientes adultos com doença periodontal, em $60 \%$ dos adultos saudáveis e não foram detectados nas crianças. Em adultos periodontalmente sadios os Bacteroides negros foram isolados em apenas 1/40 amostras de placa, contra 32/80 amostras de placa no grupo com doença periodontal. As maiores proporções de microrganismos foram isoladas da placa dentária, principalmente subgengival e da amígdala, indicando que estes sítios constituem o nicho primário dessas bactérias na cavidade bucal. As espécies predominantemente isoladas foram o $B$. intermedius seguido dos $B$. gingivalis e B. melaninogenicus. Observaram correlação positiva estatisticamente significante entre a proporção de $B$. melaninogenicus e $B$. intermedius cultiváveis e as variáveis clínicas analisadas como a profundidade de bolsa e o índice de inflamação gengival, sugerindo que esses microrganismos podem contribuir para a patogênese de certas formas de doença periodontal.

Através do teste ELISA (enzime-linked immunosorbent assay) a presença de anticorpos anti- $B$. gingivalis foi investigada por MOUTON et al ${ }^{71}$. (1981), em 140 amostras de soro obtidas do cordão umbilical (9), de bebês desdentados com menos de 6 meses de idade (12), de crianças com dentes decíduos e idades entre 
6 meses e 6 anos (30), de crianças com dentadura mista na faixa etária de 6-12 anos (24), de adultos periodontalmente saudáveis (56) e de desdentados (9). As crianças com menos de 6 meses de idade não apresentaram anticorpos lgG e poucas crianças entre 6 meses e 6 anos demonstraram anticorpos $\lg G$ para $\circ B$. gingivalis. A proporção de crianças positivas no grupo de 6-12 anos de idade foi maior que o dobro, com um aumento de três vezes no título de anticorpos comparativamente ao grupo anterior. Com base nessas observações, sugeriram que a síntese ativa de lgG para o $B$. gingivalis iniciava-se precocemente na infância e apresentava um aumento expressivo quando irrompiam os dentes permanentes. Não foi detectada resposta na classe IgM nas amostras do cordão umbilical, todavia nos primeiros 6 meses de vida do bebê, 25\% de amostras de soro apresentaram níveis detectáveis deste anticorpo, que em unidades ELISA foram cerca de metade daquele do grupo adulto (1,9 e 3,4 UE respectivamente). Nos outros grupos etários não se observaram mudanças na prevalência ou níveis de atividade desses anticorpos, mas por volta dos 12 anos de idade, $50 \%$ da população tinha atingido os níveis dos adultos periodontalmente saudáveis. Os baixos índices de anticorpos nos desdentados reforçou a idéia de que o nicho primário do $B$. gingivalis seja o sulco gengival. Os resultados mostraram correlação positiva entre o aumento da idade e o aumento na prevalência e níveis de anticorpos específicos nas classes $\lg G$, IgA e IgM. 
Um estudo epidemiológico realizado na Suécia por HUGOSON; $\mathrm{KOCH}$; RYLANDER ${ }^{35}$, em 1981, avaliou a prevalência e a distribuição de gengivite em 500 indivíduos, sendo 100 para cada um dos seguintes grupos etários: 3 e 5 anos (dentição decídua) e 10, 15 e 20 anos (dentição permanente). Considerando apenas os escores 2 e 3 dos índices de placa (Silness e Löe, 1964) e gengival (Löe e Silness, 1963), verificaram que, aos 3 anos, 52\% das crianças apresentaram placa visível, subindo para $80 \%$ aos 5 anos. Observaram gengivite em $36 \%$ e $64 \%$ das crianças nas faixas etárias de 3 e 5 anos, respectivamente; no entanto, a maioria apresentou baixa severidade da doença. A distribuição da gengivite nas idades de 3 e 5 anos foi a mesma, com maior prevalência na superfície lingual dos segundos molares inferiores e superfície vestibular dos segundos molares superiores.

A prevalência e severidade da gengivite também foram determinadas em uma amostra de 128 crianças suecas com idades entre 5 e 6 anos por SPENCER; BEIGHTON; HIGGINS ${ }^{101}$, em 1983. Verificaram o estado de higiene bucal através do índice de placa (IP) e do índice de cálculo, e o estado periodontal, através do índice gengival (IG) e registro da profundidade do sulco gengival. Os pacientes foram divididos em dois grupos: um que apresentava somente dentes decíduos, e outro que já apresentava alguns dentes decíduos substituídos por permanentes. No grupo total o índice de placa médio \pm desvio padrão (dp) foi de 1,09 $\pm 0,39$ e o índice gengival médio $\pm d p$ foi de $0,60 \pm 0,24$. Para as crianças com dentição decídua 
a média $\pm d p$ do índice de placa foi $0,66 \pm 0,24$ e a do índice gengival, de 0,66 $\pm 0,29$. Foi observada baixa correlação entre os escores dos IP e IG, embora estatisticamente significante. Mesmo tendo os resultados indicado alta prevalência de doença periodontal na amostra, a severidade foi baixa. A relação entre o acúmulo de placa e a inflamação gengival observada neste estudo foi mais fraca do que a encontrada em adultos, indicando que na dentição decídua não se pode esperar que a redução do acúmulo de placa seja recompensada pela redução da inflamação gengival.

Para determinar as possíveis diferenças na microbiota periodontal de crianças que as tornariam mais resistentes à gengivite do que os adultos, MOORE et al. ${ }^{68}$, em 1984, conduziram um estudo de gengivite experimental em 4 crianças com idades entre 4 e 6 anos comparando seus resultados aos de um estudo anterior, de metodologia semelhante, realizado em adultos ${ }^{67}$. Nas crianças, a incidência de sítios que desenvolveram escore 2 no índice gengival foi menor que 1/3 da observada em adultos. A composição da microbiota do grupo total de crianças diferiu estatisticamente da dos adultos. No total de 160 espécies isoladas, aquelas cuja proporção aumentou na microbiota com o aumento do escore do índice gengival foram Actinomyces spp., Capnocytophaga spp., E. saburreum, F. nucleatum, Selenomonas spp. (entre as quais a S. sputigena) e T. socranskii. As espécies predominantes que correlacionaram-se aos escores gengivais, tanto nos adultos como nas crianças, foram o F. nucleatum, Actinomyces WVa963, 
Selenomonas DO4 e T. socranskii. Em relação aos adultos, as crianças apresentaram proporção 1,5 vez maior de Bacteroides spp. e não apresentaram o T. denticola. Se a microbiota de crianças não tivesse sido significantemente diferente da dos adultos, deduziriam que a maior resistência das crianças à gengivite experimental refletia somente a resistência do hospedeiro. Como a incidência de algumas espécies predominantes correlacionou-se ao aumento dos escores do índice gengival, tanto em crianças como em adultos, concluíram que a resistência do hospedeiro poderia desempenhar o principal papel, mas os agentes etiológicos poderiam ser diferentes nas duas populações.

Procurando estabelecer a correlação entre a composição da placa subgengival e a severidade de gengivite na infância, MUKHEERJEE et al. ${ }^{72}$ (1985) analisaram amostras de 41 crianças com idades entre 3 e 8 anos, através do exame das porcentagens de detecção de morfotipos bacterianos, por microscopia de campo escuro. Encontraram correlação positiva entre o índice gengival e a porcentagem de espiroquetas e de bacilos móveis e negativa entre o índice gengival e formas cocóides. A porcentagem de espiroquetas também mostrou correlação estatisticamente significante com o índice de placa, profundidade de sondagem e sangramento à sondagem. 
Com o objetivo de comparar a reação gengival à placa dentária em crianças de diferentes idades e em adultos, MATSSON; GOLDBERG ${ }^{58}$, em 1985, avaliaram três grupos de crianças (com idades entre 4-6, 7-9 e 14-16 anos) e um grupo de adultos (com 20-22 anos de idade). Foram determinados o grau de gengivite e o índice de placa, verificando que para determinado escore de placa, a porcentagem de escores elevados de gengivite eram menores nas crianças de 4-6 anos, do que em crianças maiores ou adultos. Em todos níveis de acúmulo de placa, o grau mais elevado de inflamação gengival foi observado nas crianças de 14-16 anos de idade e nos adultos. Os resultados indicaram que a reatividade gengival aumenta gradualmente da infância à idade adulta.

SAWYER et al. ${ }^{86}$, em 1986, avaliaram a microbiota bucal de um grupo de 22 crianças nigerianas, com 1 a 5 anos de idade, bem nutridas e mal nutridas. As amostras de placa foram colhidas da margem dento-gengival e semeadas para cultivo. A presença de espiroquetas foi determinada através da observação microscópica de esfregaços do material amostrado. A porcentagem de isolamento das microbiotas aeróbia e anaeróbia facultativa foi igual para o grupo de crianças bem nutridas e mal nutridas; contudo, a porcentagem de isolamento da microbiota anaeróbia estrita foi significantemente maior nos pacientes mal nutridos. Os espiroquetas foram encontrados somente nas crianças mal nutridas (88\%). De 3 pacientes mal nutridos que receberam dieta hiperprotéica balanceada durante 6 meses e que foram novamente avaliados, 2 apresentaram alteração de uma 
microbiota predominantemente anaeróbia para uma na qual os anaeróbios não foram isolados. A exceção foi um dos pacientes no qual o Bacteroides oralis ainda foi isolado, embora todas as outras espécies de Bacteroides tivessem desaparecido. Estes dados demonstraram que as crianças mal nutridas apresentaram microbiota fortemente indicativa de deterioração da saúde bucal ou existência de doença bucal.

Através da microscopia de campo escuro MIKX; MATEE; SCHAEKEN 62 (1986) analisaram a microbiota subgengival de 71 crianças tanzanianas das zonas rural e urbana, com idades entre 7-9 anos e 77 crianças holandesas com 6-12 anos de idade, para verificar a ocorrência de espiroquetas na fase pré-pubertária e a relação de sua presença com o estado periodontal. Os espiroquetas foram detectados em quase todas as crianças tanzanianas (93\%) e em $66 \%$ das crianças holandesas. Os espiroquetas predominantes apresentaram tamanho pequeno e médio enquanto os espiroquetas grandes não foram observados com freqüência nas crianças tanzanianas da zona rural e nos sítios com sangramento das crianças holandesas. As porcentagens de cocos, bacilos e fusiformes indicaram que a microbiota subgengival de crianças tanzanianas difere da das holandesas. Os espiroquetas foram detectados mais freqüentemente nos sítios com sangramento do que nos sítios não sangrantes, em ambas populações. Porém, nos sítios não sangrantes das crianças tanzanianas houve maior prevalência de espiroquetas do que os sítios com sangramento das crianças 
holandesas. Concluíram que os espiroquetas são membros da microbiota normal de crianças em idade pré-pubertária, que a gengivite está associada ao aumento na proporção de espiroquetas e que sua presença no sulco gengival não é dependente da inflamação gengival.

Uma vez já investigada a bacteriologia da gengivite experimental em crianças ${ }^{68}$, MOORE et al. ${ }^{65}$ (1987) determinaram a microbiota total cultivável associada com a gengivite de ocorrência natural em adultos e crianças, comparando-a com aquelas encontradas naquele estudo, bem como na saúde, na periodontite juvenil e na periodontite moderada ou severa. Participaram do estudo 10 crianças, com idades entre 4 e 6 anos, e 11 adultos, com 24-34 anos, com gengivite e um grupo controle, com 16 adultos periodontalmente sadios. Foram encontradas diferenças significantes entre os três grupos para o índice gengival $(p<0,0001)$. O teste de Tukey mostrou que o índice gengival era significantemente maior nos adultos com gengivite que nas crianças com gengivite, e maior nestas que nos adultos sadios. O índice de placa também diferiu significantemente entre os três grupos, mas foram as crianças que exibiram os maiores escores. As microbiotas das crianças e adultos com gengivite não diferiram entre si, mas foram distintas daquelas associadas com a saúde ou a periodontite. Não houve diferença na microbiota, também entre áreas com diferentes índices gengivais. $O T$. 
denticola e o $B$. gingivalis não foram isolados de amostras de pessoas sadias ou crianças com gengivite.

A presença e os principais nichos de alguns periodontopatógenos foram investigados por FRISKEN et al. ${ }^{25}$ (1987) em crianças com idades entre 5 e 7 anos, utilizando dois métodos de isolamento. Das 67 crianças, 38,8\% apresentavam dentição decídua completa enquanto 61,2\% apresentavam dentadura mista. Os autores não observaram qualquer situação na qual uma espécie bacteriana em particular fosse detectada na placa ou na saliva das crianças com ou sem dentes permanentes irrompidos. Utilizando o método de diluição e plaqueamento espiral isolaram os Bacteroides negros em $31,1 \%$ das crianças, com a espécie $B$. intermedius sendo a mais freqüentemente detectada (21\%). O B. gingivalis foi isolado em apenas uma de 61 crianças $(1,6 \%)$ e o $A$. a. de 1/30 indivíduos, enquanto o F. nucleatum, Capnocytophaga spp. e Eikenella corrodens foram observados em mais de $60 \%$ das crianças. Quando utilizaram uma técnica de plaqueamento direto a freqüência de detecção das bactérias foi significantemente maior, sendo que o número de Bacteroides negros dobrou $(61,3 \%)$ e o de A.a. aumentou dez vezes (33,3\%). Para a Capnocytophaga spp. e o F. nucleatum não houve diferenças evidentes. Os Bacteroides negros foram isolados menos comumente de amostras de placa do que de amostras de saliva, língua ou amígdalas, mas o $B$. intermedius foi mais isolado em amostras de placa 
(44,4\%). Concluíram os autores, que alguns microrganismos periodontopáticos encontram-se freqüentemente presentes em idades precoces, tanto na placa como em outros sítios bucais.

LOESCHE ${ }^{52}$, em 1988, detectou espiroquetas através de exame por microscopia em campo escuro, na placa dentária de aproximadamente $40 \%$ de crianças com idades entre 3 e 5 anos e em aproximadamente $50 \%$ das crianças de 6-12 anos que haviam sido examinadas, correspondendo, porém a menos de 0,5\% da microbiota total, não sendo cultiváveis.

Em estudo longitudinal de 4 anos envolvendo 31 crianças na fase prépubertária (idade de 11,4 \pm 0,4 anos), VAN OOSTEN et al. ${ }^{113}$ (1988), através dos métodos de cultura e microscopia de campo escuro, observaram Bacteroides negros $\left(>10^{4}\right.$ UFC) em $75 \%$ dos indivíduos, sendo que o $B$. intermedius foi 0 mais comumente isolado e o $B$. gingivalis não foi detectado. $O B$. intermedius e 0 B. melaninogenicus foram freqüentemente detectados na placa subgengival e estavam associados com sinais clínicos de inflamação gengival. Da mesma forma os espiroquetas foram isolados com freqüência na presença de gengivite. As meninas apresentaram maiores escores de gengivite do que os meninos do mesmo grupo etário. Os Bacteroides negros apresentaram maior prevalência nas meninas em idade pré-pubertária do que nos meninos, indicando que estes microrganismos 
devem estar associados com fatores do hospedeiro ou substratos específicos utilizados para seu crescimento. Não observaram diferenças na prevalência ou proporção de espiroquetas entre os sexos. Confirmaram que os Bacteroides negros e os espiroquetas são freqüentemente encontrados em crianças na prépuberdade e que estão correlacionados com a presença de placa subgengival e com o grau de gengivite.

MARTINS; VIGGIANO; HALLA ${ }^{55}$, em 1988, avaliaram a prevalência e severidade da doença periodontal em crianças brasileiras na faixa etária de 3 a 6 anos, residentes na zona urbana da cidade de Florianópolis. Foram examinadas 243 crianças de ambos os sexos em relação a inflamação gengival, utilizando-se o índice periodontal de Russel. Os resultados mostraram prevalência de 99,60\% e apenas uma criança não apresentou comprometimento periodontal. Quanto à severidade, 105 crianças (43,21\%) apresentaram gengivite leve (0,1-1,0), 134 crianças $(55,14 \%)$ apresentaram gengivite moderada $(1,1-2,0)$ e somente 3 crianças $(1,24 \%)$ apresentaram gengivite severa $(>2,0)$.

Para determinar se o B.gingivalis e outros Bacteroides negros poderiam ser detectados em crianças, ROBERT; MOUTON ${ }^{81}$ (1989) avaliaram amostras de placa subgengival colhidas dos incisivos inferiores de 41 crianças de 6-15 anos de idade. Através da cultura isolaram o $B$. gingivalis e o $B$. intermedius de 6 crianças 
e outros Bacteroides negros de 4. Seis Bacteroides negros isolados foram perdidos antes da identificação. Vinte e duas crianças apresentaram culturas negativas para os Bacteroides negros. A imunofluorescência indireta revelou a presença de $B$. gingivalis em 28 crianças. Estes resultados indicaram que as espécies de Bacteroides negros colonizam a boca na infância e que o $B$. gingivalis seria mais prevalente (acima de $68 \%$ das crianças) do que normalmente se aceita.

Ainda em 1989, KISBY et al. ${ }^{41}$ realizaram o primeiro estudo com a tecnologia das sondas de DNA para pesquisar a presença de A.a., B. gingivalis e $B$. intermedius em amostras de placa subgengival de crianças americanas. Essa análise utiliza fragmentos espécie-específicos do DNA, que se hibridizam com o DNA pertencente ao patógeno em questão dentro de uma amostra de placa desconhecida. Uma vez que os códigos de DNA são únicos entre diferentes espécies, as sondas são sensíveis e específicas. Na investigação compararam os níveis dos três microrganismos na placa subgengival de 60 crianças na prépuberdade, com idades entre 8 e 11 anos divididas em dois grupos: sem e com evidência de gengivite e sinais clínicos de doença periodontal. Os dois grupos exibiram uma semelhança notável na incidência das 3 bactérias, sendo 0 percentual de indivíduos positivos respectivamente para o A.a., 20\% e 23\%; para o B. intermedius, $57 \%$ e $70 \%$ e para o B. gingivalis, $37 \%$ e $50 \%$. Em ambos os grupos, $98 \%$ dos sítios positivos continham menos de $10^{4}$ células de $A$.a. ou $B$. 
gingivalis, indicando baixas proporções dessas espécies. Por outro lado, foi elevada a porcentagem de sítios com níveis $++\left(10^{4}\right)$ ou $+++\left(>10^{5}\right.$ células $)$ para o B. intermedius.

Considerando a ocorrência relativamente comum de microrganismos periodontopatógenos em crianças maiores, FRISKEN; HIGGINS; PALMER ${ }^{24}$ (1990) investigaram se estes microrganismos poderiam ser detectados em 36 crianças a partir da primeira semana de vida até os 2,5 anos de idade, divididas em quatro faixas etárias: 0-1 semana, 1-6 meses, 1-2 anos, 2-2,5 anos. Através da cultura, não conseguiram isolar nenhuma das bactérias pesquisadas na primeira semana de vida. $O B$. intermedius e o $B$. melaninogenicus foram detectados a partir do primeiro mês de vida, em freqüências que variaram de 16 a $37 \%$, nos diferentes grupos etários. $\bigcirc \quad B$. gingivalis, $B$. loescheii e o $A . a$. não foram isolados. Estes resultados sugeriram que a colonização por Bacteroides negros, particularmente $\circ$ B. intermedius e $\circ$ B. melaninogenicus pode ocorrer nos primeiros meses de vida. No entanto, comparativamente ao estudo que fizeram com crianças de 5 a 7 anos ${ }^{25}$, as proporções de todas as bactérias foram menores nestas crianças, indicando que embora a incidência permaneça estável, as proporções dos microrganismos podem aumentar com o tempo. 
FONSECA ${ }^{23}$, em 1990, investigou a relação da presença de espiroquetas na placa subgengival com os níveis de inflamação gengival em 66 crianças brasileiras, com idades entre 5 a 10 anos, através do método enzimático BANA (Benzoil-DL-arginine-2-naphthylamide). O teste mostrou-se fortemente positivo em $34,8 \%$ das crianças e em $45 \%$ dos sítios examinados. Foram detectados espiroquetas em $65,15 \%$ das crianças, em pelo menos um dos quatro sítios examinados. A positividade da reação BANA e a presença de espiroquetas tendeu a aumentar com o aumento da idade. Quando os sítios sangrantes ou não sangrantes foram correlacionados com a presença ou ausência de espiroquetas não houve associação significante.

Utilizando a metodologia da sonda de DNA, com nível de detecção de $10^{3}$ bactérias, ABRAHAM et al. ${ }^{1}$, em 1990, avaliaram 50 crianças americanas com idades entre 6 e 14 anos em relação à presença de Actinobacillus actinomycetemicomitans, Bacteroides gingivalis e Bacteroides intermedius, em 4 sítios subgengivais dos primeiros molares permanentes superiores e inferiores. A amostra total foi dividida em dois grupos, segundo o índice de placa. Do número

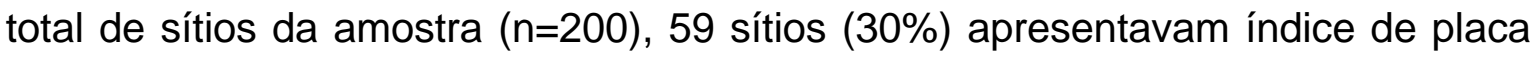
$=0$ e 141 sítios (70\%) índice de placa $\geq 1$. As porcentagens de detecção microbiana observadas nos grupos de sítios com índice de placa $=0$ e índice de placa $\geq 1$ foram respectivamente: 6,8 e $29,8 \%$ para o A.a., 44 e $61,7 \%$ para o $B$. intermedius e 20,4 e $41,8 \%$ para o B. gingivalis. O B. gingivalis não foi detectado 
sozinho em nenhum sítio amostrado, somente em combinação com $0 \quad B$. intermedius, sugerindo uma relação de sinergismo entre eles. $O B$. intermedius foi o microrganismo mais predominante, tanto no grupo de sítios com índice de placa $=0$ como no grupo com índice de placa $\geq 1$.

WATSON et al. ${ }^{121}$, em 1991, pesquisaram através dos testes BANA e ELISA para o $T$. denticola e $P$. gingivalis, se esses microrganismos poderiam ser encontrados na placa subgengival de 157 crianças com idades entre 2 e 18 anos. No grupo total, o teste BANA foi positivo em $56 \%$ das crianças. Quando analisadas separadamente, considerando os estágios da dentição foram observados $42,8 \%$ de positividade em 63 crianças com dentadura decídua, 50\% em 74 crianças com dentadura mista e $30 \%$ em 20 crianças com dentadura permanente. O teste ELISA para o grupo total revelou $79 \%$ das crianças positivas para o $T$. denticola e $80 \%$ para a $P$. gingivalis. $O$ teste BANA revelou grande especificidade, mostrando-se negativo quando as bactérias não estavam presentes, mas baixa sensibilidade, sendo negativo quando o teste ELISA detectava $B$. gingivalis e $T$. denticola. Este estudo mostrou que crianças abrigam periodontopatógenos e que esta presença pode ser relacionada com a história de doença periodontal na família.

Devido a dificuldade de se identificar espiroquetas na placa dentária, BARRON et al. $^{7}$ (1991) utilizaram anticorpos monoclonais e uma técnica 
imunoenzimática para avaliar o número relativo de espiroquetas de modo geral e, particularmente, do T. denticola. Foram coletadas amostras de placa de 40 indivíduos com idades entre 2 e 25 anos separados em 4 grupos de dez: grupo com dentadura decídua (2-4 anos), com dentadura mista (5-11 anos), com dentadura permanente (12-15 anos) e adultos jovens (16-25 anos). A prevalência dos espiroquetas totais nos quatro grupos foi respectivamente de: $50 \%, 70 \%, 70 \%$ e $90 \%$, com aumento marcante nas contagens relativas por volta dos 9-14 anos, tendo os indivíduos mais velhos maior probalidade de apresentar espiroquetas, em maior número e diferentes espécies do que os indivíduos mais jovens. As prevalências dos dois sorotipos de $T$. denticola para as quatro faixas etárias foram respectivamente de: $50 \%$ e $40 \% ; 70 \%$ e $60 \%, 70 \%$ e $60 \%$ e de $90 \%$ e $90 \%$. Esses resultados levaram a sugestão de que $\circ T$. denticola possa ser o primeiro treponema a colonizar a dentadura decídua; que o $T$. denticola parece compreender a principal proporção dos espiroquetas em todas as idades e que dois sorotipos distintos de $T$. denticola coexistem na placa dentária da maioria das crianças. $\mathrm{O}$ uso de anticorpos monoclonais para $\circ$ B. gingivalis revelou que a prevalência e o número relativo desse microrganismo foram muito baixos nas quatro faixas etárias, não indicando relação aparente com a idade. O indivíduo mais jovem a apresentá-lo tinha 9 anos.

Para caracterizar o perfil microbiológico do sulco gengival de crianças, NAKAGAWA et al. ${ }^{73}$, em 1991, examinaram amostras colhidas de dois sítios de 18 
pacientes com gengivite e de dois sítios de 18 indivíduos sadios, divididos em três estágios de maturação fisiológica: crianças em idade pré-escolar, crianças em idade escolar e crianças na circumpuberdade. Através dos métodos de cultura e microscopia de campo escuro verificaram que as mudanças nas proporções e freqüência das bactérias periodontopáticas foram distintas nos diferentes estágios de maturação fisiológica. Os Bacteroides negros foram comumente encontrados nas lesões de gengivite. $O B$. intermedius apresentou-se em níveis mais elevados no estágio circumpubertário. O A.a. foi detectado em 4 dos 12 sítios das crianças em idade escolar e em 6 dos 12 sítios do estágio circumpubertário nos portadores de gengivite. Nessa fase, a proporção de A.a. nos grupos com gengivite foi significantemente maior do que no grupo de indivíduos sadios e esses índices correlacionaram-se com o índice gengival e o índice de placa. $O$ exame microscópico mostrou que a proporção de espiroquetas nos grupos com gengivite foi significantemente maior do que nos grupos de indivíduos sadios. Os espiroquetas exibiram estreita correlação com os índices gengival e de placa nos três estágios avaliados.

A ocorrência de bactérias bucais anaeróbias Gram negativas mesmo antes da irrupção dos dentes foi examinada por KÖNÖNEN; ASIKAINEN; JOUSIMIESSOMER $^{43}$ (1992) em 30 bebês com idades entre 1 e 7 meses. As amostras foram colhidas das superfícies mucosas, bochecha, palato, língua e saliva de cada bebê e cultivadas aerobica e anaerobicamente em meios seletivos e não seletivos. 
Noventa por cento dos bebês apresentaram bactérias anaeróbias nos primeiros 3 meses de idade, sendo detectadas 11 espécies diferentes. A Prevotella melaninogenica foi a isolada com maior freqüência (70\%). A Prevotella intermedia foi encontrada em $7 \%$ dos bebês e a Porphyromonas gingivalis não foi detectada em nenhum dos bebês. Estes resultados sugerem que várias espécies de bactérias anaeróbias colonizam facilmente a boca edêntula de bebês, mas um ambiente especial, tal como o sulco gengival, pode ser pré-requisito para a colonização da $P$. gingivalis na cavidade bucal.

A detecção de várias espécies bacterianas anaeróbias Gram negativas na microbiota bucal de bebês edêntulos levou KÖNÖNEN; JOUSIMIES-SOMER; ASIKAINEN ${ }^{44}$ (1992) a questionarem a sua fonte de infecção inicial. Para investigar a possível similaridade dessas bactérias na saliva estimulada das mães (idades entre 21-41 anos) e na mucosa e saliva dos bebês do estudo anterior (idades entre 1-7 meses) as amostras foram analisadas com a mesma metodologia microbiológica utilizada. Todas as mães abrigaram F. nucleatum e 29 delas abrigaram $P$. melaninogenica em sua saliva. Em aproximadamente metade das mães os níveis salivares de $P$. melaninogenica, F. nucleatum, Prevotella spp. não pigmentada, $P$. intermedia e $P$. loescheii excederam $10^{4}$ unidades formadoras de colônias (CFU). Observaram correlação positiva somente entre a concentração salivar materna de $P$. melaninogenica e a colonização dos bebês. Não 
encontraram associação positiva para Prevotella spp., $P$. intermedia e $P$. loescheii. Nenhuma das mães ou bebês apresentou $P$. gingivalis ou $A$. actinomycetemcomitans. Especularam que a saliva materna pode agir como fonte de alguns anaeróbios Gram negativos para a microbiota bucal de bebês edêntulos.

Com o objetivo de verificar se os periodontopatógenos $T$. denticola, $P$. gingivalis e $B$. forsythus poderiam ser simultaneamente detectados em 22 pares de mães e primeiro filho e 6 pares de mães e segundo filho, BRETZ et al. ${ }^{15}$ (1993) pesquisaram esses microrganismos através da técnica de "Slot immunoblot" em amostras de placa subgengivais de mães e crianças situadas na faixa de 6 a 11 anos de idade, com média de 8,6 anos. Foi observada concordância moderada (no mínimo $25 \%$ e no máximo $75 \%$ ) para a presença do $T$. denticola nos diferentes pares e concordância quase perfeita $(90 \%)$ para a presença simultânea do $B$. forsythus em membros da mesma família. Não foi observada concordância para a $P$. gingivalis. Os autores concluíram que a presença intrafamilial de determinadas espécies periodontopatogênicas, se deve primordialmente à pais portadores de doença periodontal.

Partindo do pressuposto de que a ocorrência de doença periodontal severa na família poderia aumentar o risco de colonização de suas crianças PETIT et al. ${ }^{78}$ 
(1994) , examinaram 49 crianças na faixa etária de 3 meses até 15 anos (total de

12 entre os 3-6 anos) quanto à presença de $A$. actinomycetemcomitans, $P$. gingivalis, $P$. intermedia, espiroquetas e microrganismos móveis, altamente prevalentes em um dos pais com periodontite severa. Realizaram avaliação clínica da condição periodontal e avaliação microbiológica utilizando os métodos de imunofluorescência indireta com anticorpos policlonais e cultivo para a análise das amostras da mucosa bucal, dorso da língua, amígdalas, saliva e placa subgengival de 4 sítios. Nenhuma das crianças com idade inferior a 5 anos foi afetada periodontalmente, enquanto que entre os 5-15 anos, $26,5 \%$ apresentaram um ou mais sítios com leve perda de inserção. No total de 49 crianças, a $P$. gingivalis só foi isolada de uma criança de 5 anos, da mucosa bucal, amígdala e saliva, mas não do sulco gengival, o $A$.a. foi detectado em 5 crianças das quais a mais nova tinha 3 anos de idade e a $P$. intermedia em 34, sendo que sua ocorrência correlacionou-se com a idade, tendo 3 anos a criança mais nova que a apresentou. Formas móveis de bactérias foram vistas em 4/8 crianças na faixa etária de 0-2 anos e em 11/12 na faixa de 3-6 anos, sendo sua presença na língua três vezes maior do que no sulco gengival. A criança mais nova a apresentar espiroquetas tinha 3 anos e, na faixa dos 3-6 anos, 4/12 crianças foram positivas. Ao contrário do observado em adultos, os espiroquetas foram tão comuns na língua quanto no sulco gengival. A presença de um dos periodontopatógenos na criança sempre esteve associada à sua presença em pelo menos um dos pais. 
Com o emprego de outros métodos, WATSON; BRETZ; LOESCHE 120 (1994) avaliaram a relação entre e a presença de $T$. denticola e $P$. gingivalis ou periodontite nos pais e a presença de espécies BANA-positivas nas crianças. Foram examinadas 34 mães ou pais (faixa etária dos 26-41 anos) e 34 crianças (faixa etária dos 6-11 anos) em relação ao índice de placa, índice de sangramento gengival e presença de $T$. denticola e $P$. gingivalis em 4 amostras de placa subgengival, testadas pelo método de BANA ou pelo teste de ELISA, através de anticorpos policlonais específicos. As crianças cujos pais estavam colonizados por bactérias BANA-positivas foram 9,8 vezes mais predispostas a serem colonizadas por estas bactérias, enquanto que aquelas cujos pais apresentavam evidência clínica de periodontite apresentaram probabilidade 12 vezes maior de serem colonizadas. Os resultados corroboraram a hipótese de que as crianças possam adquirir espécies BANA-positivas de seus pais, principalmente quando estes são portadores de periodontite.

Uma vez que a irrupção dos dentes decíduos proporciona nichos adequados para a colonização bacteriana, KÖNÖNEN et al. ${ }^{45}$, em 1994, avaliaram a composição da microbiota bucal Gram negativa de uma amostra de 21 crianças na faixa etária de 24-41 meses e dentição decídua, que já haviam sido avaliadas em sua fase edêntula. Foram colhidas duas amostras de cada criança, uma amostra de placa subgengival colhida com fio dental e uma de saliva estimulada com parafina associada com material colhido com "swab" de todo revestimento 
mucoso. Realizaram o cultivo em aero e anaerobiose das amostras utilizando meios seletivos e não seletivos. Nenhuma das crianças abrigou o A.a. ou a $P$. gingivalis. Houve um aumento das taxas de ocorrência para a maioria dos anaeróbios orais Gram negativos em crianças com dentes quando comparadas ao seu período edêntulo. A detecção de $P$. intermedia aumentou de $10 \%$ para $67 \%$ e somente as prevalências de $B$. gracilis e Veillonella spp. permaneceram no mesmo nível. Detectaram também algumas espécies que não haviam sido isoladas dos bebês edêntulos tais como: $P$. denticola (71\%), outras espécies de Fusobacterium spp. (71\%) que não o F.nucletum e Selenomonas spp. (43\%). Com a irrupção dos dentes decíduos, novas espécies colonizaram as superfícies bucais e criaram uma microbiota anaeróbia Gram negativa multiforme.

Em 1994, NAKAGAWA et al. ${ }^{74}$ examinaram a resposta imune contra a $P$. gingivalis e três sorotipos de A.a., correlacionando-a com a idade e a infecção homóloga. Foram avaliados 90 indivíduos, divididos em três grupos: 40 com gengivite, 40 com periodonto sadio e $10 \mathrm{com}$ periodontite. Os dois primeiros grupos foram divididos em quatro faixas, de acordo com a idade (pré-escolar, escolar, puberdade e adulto). A $P$. gingivalis não foi detectada no grupo periodontalmente sadio, nem em crianças na faixa pré-escolar com gengivite. $O$ A.a. não foi cultivado de crianças pré-escolares sadias, mas o sorotipo c foi cultivado nessa faixa, das crianças com gengivite. Em relação aos anticorpos, no 
grupo com gengivite houve correlação positiva entre o aumento da idade e aumento dos níveis séricos de anticorpos $\lg G$ contra a $P$. gingivalis até a puberdade. No entanto, não foram observadas diferenças estatisticamente significantes nas faixas da puberdade e do adulto. $O$ nível de anticorpos lgG contra o A.a. no grupo com gengivite em idade escolar foi significantemente maior que o do grupo com gengivite em idade pré-escolar, para todos os sorotipos. Foi observada correlação positiva entre o nível elevado de $\lg G$ anti- $A$.a. e anti- $P$. gingivalis e a presença desses microrganismos na placa, tanto do grupo de indivíduos na puberdade com gengivite como no grupo de adultos com periodontite.

Utilizando a técnica do "slot immunoblot" ROSA ${ }^{82}$, em 1995, avaliou amostras de placa subgengival de 59 crianças sadias, com idades entre 3 e 6 anos, quanto a presença, distribuição e intensidade de colonização de dez bactérias: $A$. viscosus, $S$. sanguis, $S$. mutans, $P$. gingivalis, $P$. nigrescens, $A$. actinomycetemcomitans (A.a.), F. nucleatum, S. sputigena, T. denticola e $T$. vincentii. O A. viscosus foi detectado em $100 \%$ das crianças, o S. sanguis em $72,9 \%$, o S. mutans em $22,0 \%$, a $P$. nigrescens em $23,7 \%$, o $A$.a. em $52,5 \%$, o $F$. nucleatum em $57,6 \%$, a $S$. sputigena em $17,0 \%$ e o $T$. vincentii em $27,1 \%$. A $P$. gingivalis e $0 \quad T$. denticola não foram detectados. A distribuição dos microrganismos não foi homogênea, ocorrendo colonização em 1, 2, 3 ou 4 sítios. Os maiores escores médios de detecção foram observados para o $A$. viscosus 
$(0,5-3,0)$. Em geral, para os demais, os escores médios evidenciaram a baixa intensidade de colonização. Não foram observadas diferenças na detecção que pudessem ser atribuídas ao sexo (exceto para o $S$. mutans nos meninos), a idade (3-4, > $4-5,>5-6$ anos) ou a origem das amostras (mandibular ou maxilar). $\mathrm{O}$ estudo das correlações evidenciou correlações significantes entre a idade e a detecção de $P$. nigrescens; o índice de placa e o índice gengival, $A$. viscosus, $S$. sanguis, A.a. e F. nucleatum, o índice gengival e o $A$. viscosus, $S$. sanguis, $P$. nigrescens, $A$. a. e T. vincentii e entre todas as bactérias, exceto entre a $P$. nigrescens e o $A$. viscosus, $S$. sanguis, $S$. mutans, $F$. nucleatum, e entre $S$. sputigena e o $A$. viscosus, $P$. nigrescens e $T$. vincentii. Concluiu que a microbiota do sulco gengival na dentição decídua é constituída predominantemente por bactérias Gram positivas da placa básica, podendo abrigar alguns, mas não todos os organismos considerados periodontopatógenos potenciais.

Também em 1995, SIXOU; BONNAURE-MALLET; MOUTON ${ }^{93}$ avaliaram, através do teste ELISA, a presença de anticorpos contra a cepa de Porphyromonas gingivalis ATCC 33277 em amostras de soro de 41 crianças com periodonto sadio e idades entre 1 e 16 anos, utilizando dois diferentes antígenos: pérolas de vidro revestidas com extrato de superfície celular (GBE) ou lipopolissacarídeo (LPS). Os pacientes foram divididos em 4 grupos sendo 10 com dentição decídua, 16 com dentadura mista (5-8 anos de idade), 10 com dentadura mista (9-11 anos de idade) e 5 com dentição permanente (12-16 anos de idade). 
No grupo total também se pesquisou o microrganismo, o qual foi detectado por imunofluorescência, utilizando anticorpos monoclonais espécie-específicos, em 41\% (17/41) das crianças e isolado de um único indivíduo com 15 anos de idade $(2,4 \%)$. A presença de anticorpos $\lg M, \lg G$ e $\lg A$ detectados nos soros contra GBE foram respectivamente $95 \%, 100 \%$ e $66 \%$ e contra o LPS, $100 \%$, $95 \%$ e $61 \%$, indicando que anticorpos contra a $P$. gingivalis são altamente prevalentes no soro de crianças e sugerindo que tanto uma resposta imune primária quanto uma resposta imune secundária estejam em andamento. Os dados obtidos também suportaram a hipótese de que a $P$. gingivalis seja membro endógeno da microbiota bucal em humanos.

Com a finalidade de estudar a distribuição e possíveis vias de transmissão dos periodontopatógenos $P$. intermedia e $P$. nigrescens, VAN STEENBERGEN et al. $^{115}$, em 1995, investigaram clinica e microbiologicamente 5 pacientes com doença periodontal, seus esposos e 7 de seus filhos. As presenças de $P$. intermedia e $P$. nigrescens foram determinadas por técnicas de cultura em amostras de placa subgengival, saliva, língua, amígdalas e mucosa bucal. De todos 5 pacientes com doença periodontal, 3 esposos e 3 crianças a $P$. intermedia foi isolada de um ou mais sítios bucais. Os sítios bucais foram significantemente mais positivos para a $P$. intermedia nos pacientes com doença periodontal do que nos esposos ou filhos. A ribotipagem de um total de 44 isolados de $P$. intermedia permitiu identificar nas pessoas o que existia em comum. Uma criança apresentou 
o ribotipo de $P$. intermedia que estava presente também em sua mãe; em outra criança foram detectados dois ribotipos, dos quais um foi encontrado em um dos pais e uma terceira criança foi colonizada com um ribotipo de $P$. intermedia não encontrado nos membros da família. Concluíram que os indivíduos podem abrigar vários tipos clonais diferentes de $P$. intermedia. Foram encontrados tipos indistinguíveis tanto entre pares casados como entre pais e filhos, indicando que a transmissão dessa espécie pode ser possível tanto em idades menores como na idade adulta. Nada foi dito sobre a P.nigrescens.

Em 1996, ASIKAINEN; CHEN; SLOTS ${ }^{5}$, examinaram a probabilidade de transmissão entre casais e entre pais e filhos dos periodontopatógenos A.a. (124 indivíduos em 47 famílias) e $P$. gingivalis (78 indivíduos em 31 famílias). Os dois microrganismos foram isolados de amostras de placa subgengival e da superfície da língua e caracterizados geneticamente através do método PCR (polymerase chain reaction). Com um dos pares positivos para a bactéria, o A.a. revelou transmissão inter-pares em 4/11 (36\%) dos casais e a $P$. gingivalis em 2/10 (20\%) dos casais. A transmissão pais-filhos do A.a. ocorreu em 6/19 (32\%) das famílias. A $P$. gingivalis não foi transmitida entre pais e filhos em nenhuma das famílias estudadas. Segundo os autores, a transmissão intra-familiar do A.a. e $P$. gingivalis pode, em parte, explicar o padrão familial da periodontite e ter importantes implicações no tratamento e profilaxia desta doença. 
Para determinar a idade de aquisição da $P$. gingivalis, MCCLELLAN; GRIFFEN; LEYS ${ }^{61}$ (1996) examinaram a prevalência deste periodontopatógeno em estudo transversal. De 198 crianças, com idades entre 0 e 18 anos (pelo menos 10 indivíduos em cada ano), foram colhidas amostras da língua, mucosa vestibular e sulco mesial de cada dente presente, para análise através do método PCR. A P. gingivalis foi detectada em $37 \%$ dos indivíduos examinados, em freqüências similares para cada grupo etário, mesmo entre indivíduos com menos de um ano de idade. Nas crianças de 5 e 6 anos de idade as freqüências de detecção da $P$. gingivalis foram respectivamente de 50 e 30\%. O indivíduo mais jovem no qual foi a bactéria detectada tinha 20 dias de idade. Não houve associação entre idade e colonização sugerindo que a $P$. gingivalis pode ser adquirida nos primeiros dias de vida, mesmo na ausência de dentes, uma vez que o sulco gengival era considerado seu nicho ecológico primário.

A prevalência de 8 periodontopatógenos, entre eles a $P$. gingivalis, a $P$. intermedia e o T. denticola foi determinada por ASHIMOTO et al. ${ }^{4}$, em 1996, utilizando o método de detecção de PCR baseado no RNAr 16S, em 50 pacientes com periodontite avançada, 50 adultos com gengivite leve e 50 crianças (com idades entre 2-11 anos) com gengivite leve. Compararam também a efetividade dos métodos PCR, cultura e sonda de DNA, para a identificação das espécies. 
Nas crianças, a prevalência de $P$. gingivalis foi de $14 \%$, da $P$. intermedia $18 \%$ e do $T$. denticola $16 \%$, sendo significantemente maior no grupo com periodontite avançada do que nos outros dois grupos, sugerindo que esses microrganismos não sejam os principais componentes da placa subgengival em pacientes sem periodontite. A igualdade dos resultados na detecção da $P$. gingivalis entre os métodos PCR e sonda de DNA foi observada em $70 \%$ dos casos, enquanto que entre os métodos PCR e cultura foi de $49 \%$ dos casos. Este estudo demonstrou a utilidade do método PCR baseado no RNAr 16S, para identificar importantes microrganismos subgengivais. Os resultados indicaram uma forte associação entre as espécies estudadas e a periodontite. Várias relações simbióticas ainda não publicadas foram observadas entre as 8 espécies testadas, entre elas o A.a. / B. forsythus e E. corrodens / P. gingivalis que foram previamente citadas como associações negativas.

MÄTTÖ et al. ${ }^{59}$, em 1996, avaliaram a distribuição da $P$. intermedia e P.nigrescens na cavidade bucal de 53 adultos (27-70 anos), sendo 10 com periodonto sadio, $23 \mathrm{com}$ periodontite inicial e $20 \mathrm{com}$ periodontite avançada e de 6 crianças (2-3 anos). As amostras de placa subgengival e de saliva estimulada foram cultivadas em ágar Brucella e o DNA cromossômico das P.intermedia e P.nigrescens cultivadas foi extraído e utilizado para hibridização com sondas de oligonucleotídeos espécie-específicas não radioativas e para ribotipagem. 
Somente a P.nigrescens foi detectada em 4/6 crianças e nos 10/10 adultos periodontalmente sadios. A P.nigrescens predominou em 21/23 adultos com periodontite inicial, sendo que 6/23 abrigaram simultâneamente as duas cepas. Nos pacientes com periodontite avançada, as P.intermedia/P.nigrescens foram detectadas em 7/20, e a P.intermedia e a P.nigrescens foram encontradas isoladamente em 7/20 e 6/20, respectivamente. Concluíram que a P.intermedia e a P.nigrescens podem colonizar simultâneamente a cavidade bucal e que a P.intermedia parece estar associada à doença periodontal, devido sua ausência em adultos periodontalmente sadios e em crianças. A análise genética das cepas de P.intermedia e P.nigrescens sugeriu a transmissão dessas bactérias entre casais.

A distribuição de vários periodontopatógenos potenciais, entre os quais, a $P$. intermedia, a $P$. nigrescens e a $P$. gingivalis, foi pesquisada em amostras de placa gengival de indivíduos periodontalmente sadios, nas faixas de 3-5 anos, 9-10 anos, 24-27 anos, por CONRADS et al. ${ }^{16}$ (1996), utilizando uma técnica recémdesenvolvida de PCR e um ensaio de hibridização "dot-blot". Das três bactérias mencionadas, somente a $P$. nigrescens foi detectada em todas as faixas etárias. 
As relações entre a composição microbiana da placa subgengival e a perda de contato entre os dentes causada por cáries ou perda óssea alveolar em molares decíduos, foram avaliadas por BIMSTEIN et al. ${ }^{9}$, em 1996. Através de exame radiográfico interproximal, selecionaram 20 crianças na faixa etária de 6-10 anos, sendo 10 com perda de contato devido à cárie proximal entre os dois molares decíduos com pelo menos um sítio com perda óssea alveolar e um sítio sem (grupo A) e 10 crianças sem perda óssea alveolar, mas com sítios exibindo ou não perda de contato, devido à cárie proximal (grupo B). A composição microbiana da placa subgengival foi examinada através da microscopia de campo escuro e por cultura para o total de bactérias anaeróbias, o A.a. e a $P$. gingivalis. A microscopia de campo escuro confirmou que os espiroquetas e bacilos móveis devem ser parte da microbiota indígena da cavidade bucal em crianças. No entanto, suas proporções foram significantemente maiores na placa subgengival dos sítios de crianças com perda óssea alveolar do que nas demais. O A.a. e a P.gingivalis foram detectados nos dois grupos de pacientes; a $P$. gingivalis em 10/10 crianças do grupo $A$ e em $7 / 10$ crianças do grupo $B$, e o $A$. a. em 4/10 crianças do grupo A e 2/10 do grupo B. Nos sítios com o A.a. foram evidentes maiores proporções de espiroquetas, menores quantidades de cocos e mais colônias de P.gingivalis. Não foram evidenciadas diferenças significantes nas bactérias anaeróbias entre os sítios com ou sem perda de contato e com ou sem perda óssea alveolar. Concluíram que a composição microbiana da placa dentária está relacionada à perda óssea alveolar na dentição decídua, mas não com a perda de contato por si só. 
Em um estudo longitudinal de 3 anos PERETZ; MACHTEl; BIMSTEIN ${ }^{77}$, em 1996, examinaram a relação entre placa dentária, inflamação gengival e profundidade do sulco gengival em 78 crianças (41 meninos e 37 meninas com idades entre 1 e 12 anos no exame inicial) que residiam em uma comunidade rural em Israel, rotineiramente atendidas em uma clínica odontológica a cada 6 meses. Os parâmetros clínicos utilizados nessa avaliação foram o índice de placa, índice gengival e profundidade do sulco gengival, aferidos no início da investigação e após 12, 24 e 36 meses. O índice de placa permaneceu essencialmente o mesmo durante o período do estudo, tanto para os dentes decíduos como para os permanentes, enquanto que o índice gengival e a profundidade do sulco aumentaram. A profundidade do sulco gengival foi significantemente maior nas crianças mais velhas a cada exame anual $(p<0,001)$. Houve uma forte correlação entre a idade e a profundidade de sulco a cada exame anual. A comparação do índice de placa e índice gengival com a profundidade do sulco gengival não mostrou diferenças estatísticas. Os resultados desta pesquisa fortalecem a hipótese de que o aumento da profundidade do sulco gengival em crianças e adolescentes jovens esteja principalmente associado à idade e em um grau muito menor à resposta inflamatória. 
Uma investigação pioneira da transmissão do periodontopatógeno $P$. gingivalis entre várias gerações familiares foi realizada por TUITE-MCDONNELL et al. ${ }^{110}$ (1997), que pesquisaram 564 membros de 104 famílias contendo, em sua maioria, os pais, uma criança e pelo menos um dos avós, residentes em Columbus, Ohio, aleatoriamente selecionados. $O$ estado de colonização da $P$. gingivalis nesses indivíduos foi determinado através do método PCR, com prevalência de $37 \%$ na amostra total. Entre as 4 gerações examinadas, a prevalência variou de $27,1 \%$ nas crianças a $50 \%$ nos bisavós. As crianças foram significantemente menos freqüentemente colonizadas do que seus avós, mas não foram observadas diferenças estatisticamente significantes entre as crianças e seus pais ou entre seus pais e avós. A concordância de colonização entre crianças e suas mães mostrou que uma mãe colonizada dá a criança um risco 4,65 vezes maior de ser colonizada do que as mães que não são colonizadas. Similarmente, um pai colonizado dá a criança um risco 2,98 vezes maior para a colonização. Os riscos para a colonização foram ainda maiores para as crianças que tinham os dois pais colonizados. Os resultados mostraram que o contato com um membro familiar infectado aumenta substancialmente o risco relativo de colonização nos pares intrafamiliares, indicando que a $P$. gingivalis é comumente transmitida pelo contato com um membro familiar infectado.

Visando pesquisar a distribuição e vias de transmissão da $P$. intermedia e P. nigrescens entre membros da mesma família, VAN STEENBERGEN et al. ${ }^{116}$ 
(1997) selecionaram sete pacientes com periodontite moderada a severa, suas esposas e 14 filhos, com idades entre 0 e 10 anos, para estudar suas amostras de placa subgengival, saliva, língua, amígdalas e mucosa bucal através da cultura, diferenciar as duas bactérias através da eletroforese de enzimas e caracterizar os isolados através da ribotipagem. De todos os 7 pacientes, 4 esposos e 3/6 filhos, entre 5-10 anos de idade, foram isoladas $P$. intermedia, enquanto a $P$. nigrescens foi detectada em 2 dos 7 pacientes, 5 esposos e 5/6 filhos, entre 5-10 anos de idade e 1/8 filhos na faixa de 0-4 anos. Foram detectados ribotipos indistinguíveis de $P$. intermedia e $P$. nigrescens tanto entre casais como entre pais e filhos, indicando que a transmissão intrafamilial desses microrganismos é possível tanto entre adultos como entre pais e filhos.

As condições de higiene bucal e o grau de inflamação gengival foram verificadas por JAHN; JAHN ${ }^{36}$, em 1997, em 83 crianças brasileiras na faixa etária de 1 a 5 anos, de classe social baixa, pertencentes a uma creche na cidade de São Paulo. Para o diagnóstico de gengivite foi utilizado o índice gengival (IG) de Löe e Silness e a quantidade de placa dentária foi estimada através do índice de higiene oral simplificado (IHO-S). Os autores verificaram que apenas 13 crianças $(15,66 \%)$ apresentaram $I G=0,70$ (84,34\%) apresentaram IG $\geq 1$ e destas, 44 crianças $(53,01 \%)$ apresentaram $I G \geq 2$ e 4 crianças $(4,82 \%) \quad I G=3$. A média do IHO-S do grupo total foi de 2,3 , enquanto que a média total do IG foi de 0,84 . A alta prevalência de gengivite $(84,34 \%)$ observada neste estudo está relacionada ao 
grande acúmulo de placa dentária, demonstrando a necessidade do diagnóstico precoce da doença periodontal na infância e a importância da motivação e instrução de higiene bucal, principalmente aos pais das crianças na faixa etária avaliada.

Em um estudo realizado por KÖNÖNEN et al. ${ }^{48}$ (1999), foram avaliados longitudinalmente a época e a sucessão de colonização de anaeróbios bucais em 44 bebês caucasianos saudáveis com 2, 6 e 12 meses de idade. Amostras de saliva não estimulada foram quantitativamente cultivadas em ágar Brucella sangue e em vários meios seletivos para o isolamento dos microrganismos anaeróbios. O anaeróbio mais freqüentemente isolado em bebês com 2 meses de idade foi a Veillonella spp. A P. melaninogênica também representou espécies de colonização precoce, com a freqüência de colonização aumentando marcadamente durante o primeiro ano de vida, enquanto que a Prevotella intermedia mostrou-se um colonizador tardio. O F. nucleatum foi a espécie anaeróbia isolada com maior freqüência nos bebês com 1 ano de idade, sendo ocasionalmente encontradas outras fusobactérias. Com exceção da presença comum dos microaerófilos/facultativos Actinomyces spp., outras espécies anaeróbias Grampositivas estiveram presentes em apenas alguns bebês. Uma vez estabelecidas, as espécies colonizadoras pioneiras tenderam a persistir na boca. O estudo demonstrou o estabelecimento de várias espécies anaeróbias, com constantes aumentos de freqüência, durante o primeiro ano de vida. 
Estabelecendo um sistema de tipagem, que usa uma combinação de PCRribotipagem e PCR arbitrariamente iniciada (AP-PCR), para $P$. intermedia e $P$. nigrescens, FUKUI et al. $^{26}$ (1999) aplicaram-nas ao estudo da presença intrafamilial dessas espécies na cavidade bucal de 18 famílias, envolvendo o pai, a mãe e um filho. Em seis famílias, cujos filhos tinham idades entre 4 e 15 anos, os três membros apresentavam a $P$. intermedia, em "sensu lato". A P.intermedia foi detectada em $3 / 6$ crianças e a $P$. nigrescens em 5/6 crianças. Cepas do mesmo subtipo eram compartilhadas por membros de uma mesma família, mas não por membros de outras famílias. O estudo demonstrou que tanto a P.intermedia como a $P$. nigrescens eram predominantes em adultos e crianças; que o(s) mesmo(s) genotipo(s) de ambas as espécies podiam colonizar esposos ou pais e filhos e que cada família parece carregar subtipo(s) distinto(s) dessas espécies. 
3 Proposição 


\section{PROPOSIÇÃO}

Em crianças portadoras de fissura completa de lábio e palato unilateral, já operadas, e crianças não fissuradas, com dentadura decídua e idades entre 5 e 6 anos, propomo-nos comparar:

- as condições clínicas, levando em conta o índice de placa e o índice gengival;

- os graus de severidade dos índices de placa e gengival;

- os parâmetros clínicos da região bucal anterior com os da posterior, no grupo de portadores de fissura;

- a prevalência de P.gingivalis, P.nigrescens e T. denticola em amostras de placa subgengival, empregando-se o método de detecção bacteriana "slot immunoblot" (SIB). 
4 Material e Métodos 


\section{MATERIAL E MÉTODOS}

\section{Seleção da amostra}

Fizeram parte do estudo 57 crianças com idades entre 5 e 6 anos e dentição decídua completa, sendo 30 crianças portadoras de fissura completa de lábio e palato unilateral, já operadas e regularmente matriculadas no Hospital de Reabilitação de Anomalias Craniofaciais (HRAC), da Universidade de São Paulo, em Bauru (grupo experimental) e 27 crianças não fissuradas, moradoras de um núcleo habitacional da periferia da cidade de Bauru, Estado de São Paulo (grupo controle). Como pré-requisito para participação no estudo, estas crianças deveriam apresentar boa saúde e não ter recebido antibioticoterapia nos três meses que antecederam a colheita das amostras. Todos os pacientes da amostra foram convidados a participar da referida pesquisa tendo recebido, após exame e colheita das amostras, um tratamento preventivo que constou de profilaxia da boca toda e aplicação tópica de flúor. Os pais das crianças dos dois grupos assinaram uma autorização prévia para esta participação (ANEXOS A e B) e o trabalho foi devidamente aprovado pelo Comitê de Ética (ANEXO C).

A avaliação, do que se considerou boa saúde geral das crianças portadoras de fissura, foi realizada com base no prontuário do Hospital que é bastante completo e contém informações sobre a história clínica do paciente em diversas especialidades (pediatria, otorrinolaringologia, cirurgia plástica, anestesiologia, cardiologia, neurologia etc.). Informações adicionais foram 
fornecidas pelas mães, das ocorrências observadas após a última visita, como manifestações de qualquer ordem (infecções, acidentes, alergias, etc.) e medicamentos utilizados nos últimos meses. Em casos de dúvida os pacientes foram encaminhados para serem reavaliados pela área médica específica. Cabe aqui salientar que todos os pacientes portadores de cardiopatias com risco à endocardite bacteriana, assim como outras doenças sistêmicas graves, já estão destacados através de anotações na primeira página deste prontuário, que obrigatoriamente é consultada antes de qualquer procedimento odontológico. 


\section{MATERIAL}

SALINA TAMPÃO FOSFATO (PBS - 0,05M, pH 7,4)

$\mathrm{NaCl}$ (Fisher) $\quad 8,0 \mathrm{~g}$

$\mathrm{Na}_{2} \mathrm{HPO}_{4}$ (Mallinckrodt) $\quad 1,2 \mathrm{~g}$

$\mathrm{KCl}$ (Fisher) $\quad 0,2 \mathrm{~g}$

$\mathrm{KH}_{2} \mathrm{PO}_{4}$ (Fisher) $\quad 0,2 \mathrm{~g}$

Água destilada q.s.p $\quad 1000 \mathrm{ml}$

SOLUÇÃO DE TRANSPORTE E MANUTENÇÃO (contém inibidores de proteases, para preservação das amostras de placa):

PBS contendo por litro :

EDTA (Sigma)

Fluoreto de fenilmetilsulfonil (Sigma)

Pepstatin A (Sigma)

Formaldeido (Mallinckrodt)
$2,0 \mathrm{mM}$

$1,0 \mathrm{mM}$

$10^{-7} \mathrm{M}$

$0,5 \mathrm{mg} /$ litro

Solução distribuída em criotubos (Vanguard) em porções de 0,5 ml e armazenada a $-20^{\circ} \mathrm{C}$ até o uso. 
SALINA TAMPÃO TRIS (TBS) 0,05M, pH 7,5

Tris Base (Sigma)

$\mathrm{NaCl}$ (Mallinckrodt)

Água destilada q.s.p.
$2,42 \mathrm{~g}$

$29,24 \mathrm{~g}$

$1000,00 \mathrm{ml}$

SALINA TAMPÃO TRIS-TWEEN (TBS-T) 0,05M, pH 7,5

Tris Base (Sigma)

Tris $\mathrm{HCl}$ (Sigma)

$\mathrm{NaCl}$ (Mallinckrodt)

Tween 20 (Intermatt)

Água destilada q.s.p.
$1,20 \mathrm{~g}$

$1,59 \mathrm{~g}$

$29,22 \mathrm{~g}$

$0,50 \mathrm{ml}$

$1000,00 \mathrm{ml}$

LEITE EM PÓ DESNATADO (BLOTTO - Bovine Lacto Transfer Technique Optimizer) (Molico)

TBS-Tween 2: é a TBS mais $2 \%$ de Tween 20

TBS-BLOTTO: é a TBS mais $0,5 \%$ de BLOTTO

TBS-T-BLOTTO: é a TBS-T mais 0,5\% de BLOTTO 
CONCANAVALINA A BIOTINILADA (Vector Laboratories) - lote n.81209

STREPTAVIDIN-FOSFATASE ALCALINA (Zimed Laboratories) - lote n.80642188

SORO DE CABRA ANTI-IgG DE COELHO (H+L) CONJUGADO À FOSTAFASE ALCALINA (Zimed Laboratories) - lote n. 80642143

SUBSTRATO PARA A FOSFATASE : BCIP/NBT (5-bromo-4-cloro-3-indolil-fosfato $0,21 \mathrm{~g} / \mathrm{l}$ e nitroblue tetrazolium 0,42 g/l) (Kirkegaard \& Perry) - lote TF 018

MEMBRANAS DE NITROCELULOSE (BA85-SP 0,45 $\mu \mathrm{m}$ - Schleicher \& Schuell) Usadas após umedecimento. Proteínas e ácidos nucléicos não se aderem à membrana seca. Sua manipulação é feita sempre com luvas sem talco para evitar qualquer ligação inespecífica.

PAPEL DE FILTRO E SUPORTE (GB002-SB - Schleicher \& Schuell)

ANTÍGENOS BACTERIANOS SONICADOS - Usados como padrões em concentrações variando de 100,0 a 1,0 $\mu \mathrm{g} / \mathrm{ml}$ em água destilada estéril :

Porphyromonas gingivalis ATCC 33277

Prevotella nigrescens ATCC 33563

Treponema denticola ATCC 35405 


\section{SOROS DE COELHO ESPECÍFICOS PARA OS MICRORGANISMOS CITADOS}

Anti-soros policlonais altamente específicos desenvolvidos no Laboratório de Microbiologia da Faculdade de Odontologia da Universidade de Michigan, EUA e testados frente a um painel dos microrganismos mais comumente isolados da cavidade bucal, para determinar a ausência de reações cruzadas.

APARELHO DE ULTRA-SOM ( Vibra Cell - modelo VC 50T - Sonics \& Materials )

APARELHO OSCILADOR (Red Rocker modelo PR50 - Hoefer Scientific Instruments)

SISTEMA MINIFOLD II SLOT BLOT (Schleicher \& Schuell)

Trata-se de dispositivo contendo três partes com uma área de filtração de 6,0 $\mathrm{mm}^{2}$. Há um total de 72 fendas distribuídas em 3 fileiras, com 24 ranhuras cada.

A primeira parte é a base, que juntamente com a segunda parte formam uma câmara onde o vácuo é aplicado. Entre a segunda e a terceira partes são colocadas duas fitas de papel de filtro. A membrana de nitrocelulose é colocada nas costas da parte superior. Todo o conjunto é fechado com duas presilhas, do que resulta uma distribuição homogênea de forças dos dois lados, de modo a haver homogeneidade na filtração das amostras (FIGURA 6). 


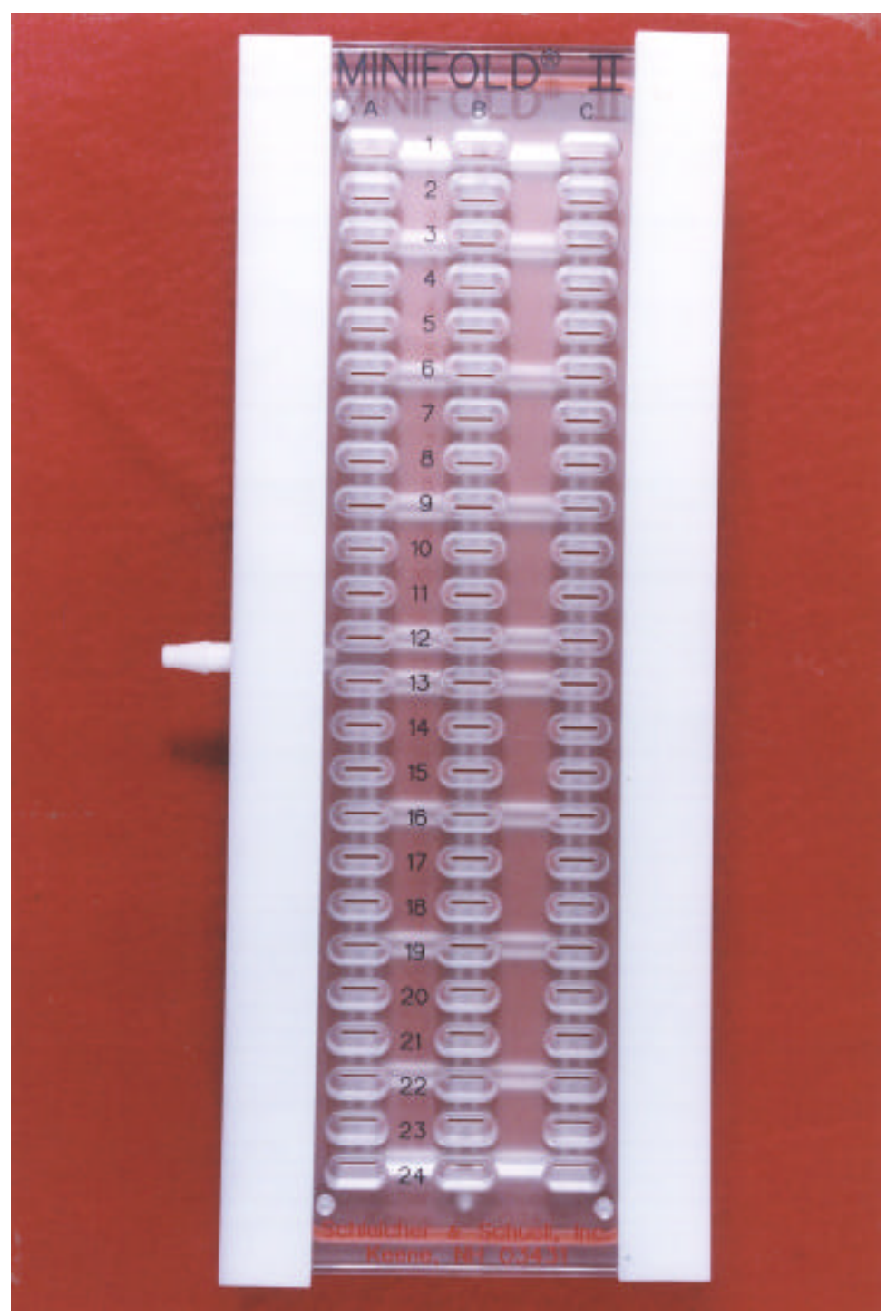

FIGURA 6 - Sistema Minifold II Slot Blot (Schleicher \& Schuell). 


\section{MÉTODOS}

\section{1- Exame Clínico das Crianças}

O exame clínico das crianças portadoras de fissura foi realizado no consultório odontológico do Setor de Odontopediatria do HRAC-USP, utilizando o aparelho de iluminação do equipo, espelho e sonda exploradora número 5 esterilizados e materiais descartáveis. As crianças do grupo controle foram examinadas no consultório odontológico da Escola Prof. Isaac Portal Roldan, sob as mesmas condições do grupo experimental.

Foram determinados os índices de placa (IP) e gengival (IG), segundo LÖE ${ }^{50}$ (1967), para todas as crianças os quais foram anotados em ficha, conforme modelo anexo (ANEXO D).

Escores para o índice de placa:

grau 0 - ausência de placa na área gengival;

grau 1 - há uma película de placa que se adere à margem gengival livre e área adjacente do dente, podendo ser reconhecida apenas pela passagem de uma sonda pela superfície do dente;

grau 2 - acúmulo moderado de depósitos moles no sulco gengival, na margem gengival e/ou superfície dental adjacente, que pode ser visto a olho nu;

grau 3 - acúmulo abundante de material mole no sulco gengival e/ou na margem gengival e superfície dental adjacente. 
Escores para o índice gengival:

grau 0 - gengiva normal;

grau 1 - inflamação leve - ligeira modificação na cor, ligeiro edema. Nenhum sangramento à sondagem;

grau 2 - inflamação moderada - gengiva edemaciada, brilhante e avermelhada ou vermelho azulada. Sangramento à sondagem;

grau 3 - inflamação severa - gengiva marcadamente vermelha ou vermelho azulada e edemaciada. Ulceração. Tendência ao sangramento espontâneo.

A severidade da inflamação gengival é definida segundo faixas que utilizam esses escores como referência: inflamação de grau baixo (escores de 0,1 - 1,0), moderado $(1,1-2,0)$ e alto $(2,1-3,0)$. O autor não menciona graus de severidade para o índice de placa, mas por analogia foram considerados: baixo $(0,1-1,0)$, moderado $(1,1-2,0)$ e alto $(2,1-3,0)$.

\section{2 - Colheita das amostras de placa subgengival}

Do grupo experimental foram colhidas seis amostras por criança, sendo duas da região lingual dos segundos molares decíduos inferiores, duas da região vestibular dos segundos molares decíduos superiores e duas dos dentes adjacentes à fissura sendo um do segmento maior $(F)$ e outro do segmento menor (f), das faces adjacentes à fissura (FIGURA 7). Do grupo controle foram colhidas quatro amostras por criança, duas da região lingual dos segundos molares decíduos inferiores e duas da região vestibular dos segundos molares decíduos 
superiores. Inicialmente, os locais foram isolados com rolos de algodão e a placa supragengival foi cuidadosamente raspada com cureta, e depois com algodão, para evitar a contaminação da amostra subgengival. Em seguida, com cureta estéril, a placa subgengival de cada região foi raspada e colocada em criotubos contendo $0,5 \mathrm{ml}$ da solução de transporte e manutenção. Após a identificação dos frascos, as amostras foram estocadas a $-20^{\circ} \mathrm{C}$ até o momento do processamento. Todos os procedimentos clínicos foram realizados pelo mesmo investigador.

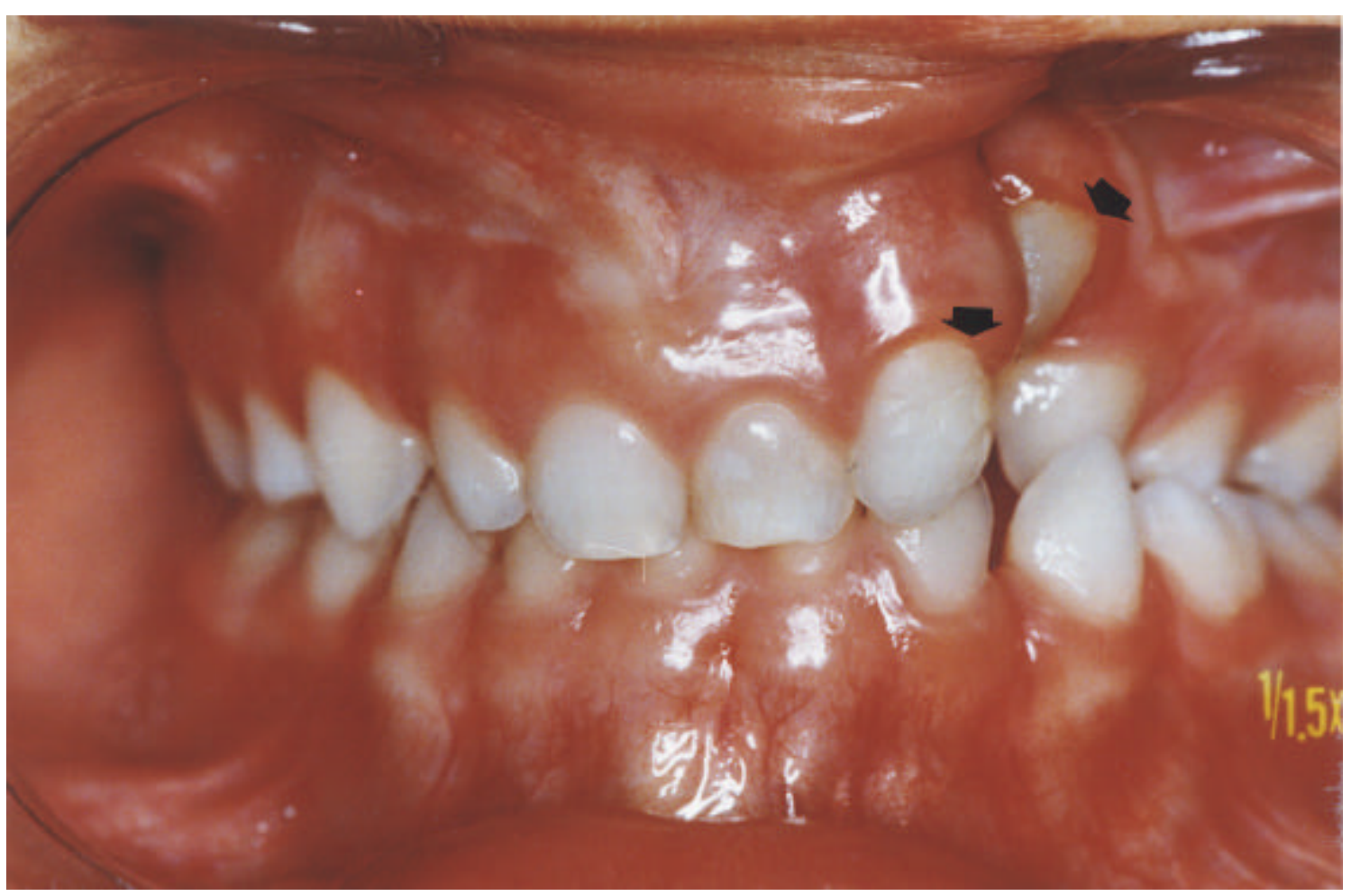

FIGURA 7 - Local da colheita da amostra nos dentes adjacentes à fissura (grupo experimental). 


\section{3 - Sonicação das amostras}

Após a calibração do aparelho "Vibra cell", as amostras foram submetidas à ultrasonicação durante 6 segundos, com a saída de energia em $60 \%$, para dispersar os agregados de placa. Entre a sonicação de uma e outra amostra, o aparelho foi acionado em álcool $70 \%$ p/v, para desinfecção e eliminação de qualquer partícula aderida.

\section{4 - Avaliação da quantidade de placa através da determinação do conteúdo de carboidrato ${ }^{114}$.}

Para esta avaliação foi utilizado como controle positivo o leite em pó desnatado "Molico", o BLOTTO em quatro concentrações diferentes $(50 \mu \mathrm{g} / \mathrm{ml}$, $10 \mu \mathrm{g} / \mathrm{ml}, 5 \mu \mathrm{g} / \mathrm{ml}$ e $1 \mu \mathrm{g} / \mathrm{ml}$ em água destilada), definidas a partir de testes para padronização.

- Preparo do Dispositivo

A membrana de nitrocelulose foi embebida em TBS $0,05 \mathrm{M}, \mathrm{pH} 7,5$, por 30 minutos. A seguir, duas folhas de papel de filtro previamente umedecidas em TBS foram colocadas sobre o suporte de filtração do Minifold II e a membrana de nitrocelulose aplicada contra a placa que contém as fendas para colocação das amostras. Qualquer bolha existente sob a membrana era eliminada através de compressão com os dedos enluvados. A parte do dispositivo com a membrana foi colocada então sobre aquela contendo o papel de filtro, para minimizar o 
aprisionamento de bolhas, que pode levar à dispersão da amostra, e o conjunto foi mantido firmemente preso através de duas presilhas de plástico laterais. Montado o Minifold II e mantido em posição vertical, foi feito o vácuo de baixa intensidade (cerca de $1 \mathrm{ml} / \mathrm{min}$ ), com bomba de vácuo "Brasil" durante 1-2 minutos, para remover o excesso de líquido.

- Colocação das amostras

Com micropipeta, foram aplicados $10 \mu \mathrm{l}$ das diluições do padrão BLOTTO e das amostras das crianças nas fendas, deixando duas fendas vazias, como controles negativos. Terminada a aplicação, foi feito o vácuo novamente e removida cuidadosamente a membrana de nitrocelulose do Minifold II colocando-a em $100 \mathrm{ml}$ de TBS-Tween 2, por 60 minutos, para bloquear os sítios não ocupados.

- Emprego da Lectina

Após lavagem de 5 minutos em TBS-T, a membrana foi colocada em 100 ml de concanavalina A biotinilada diluída a 1:1000 em TBS-T, e incubada por 1 hora.

- Uso da streptavidin-fosfatase alcalina

Depois de três lavagens de 5 minutos cada uma com TBS-T, a membrana foi incubada em $100 \mathrm{ml}$ de solução de streptavidin-fosfatase alcalina diluída a 1:1000 em TBS-T por 1 hora, seguida de outras 2 lavagens com TBS-T e uma com TBS, todas com duração de 5 minutos. 
- Revelação da reação

A revelação da reação foi feita com a adição de $10 \mathrm{ml} /$ tira de $\mathrm{BCIP} / \mathrm{NBT}$ à membrana de nitrocelulose, sendo esse contato mantido por 6 minutos, sob agitação manual. Para suspender a ação do revelador, foram feitas três lavagens de 1 minuto cada em água destilada, sendo então a membrana secada ao ar. Tanto a embebição como as lavagens e as incubações foram feitas sob agitação no aparelho oscilador, em temperatura ambiente.

\section{5 - Detecção das bactérias nas amostras de placa ${ }^{114}$}

O procedimento foi o mesmo descrito para o carboidrato, apenas utilizando reagentes diferentes.

- Colocação das amostras

Após o vácuo, os controles, previamente padronizados, formados pelas culturas bacterianas puras, diluídas em água destilada, nas concentrações de $10 \mu \mathrm{g} / \mathrm{ml}, 5 \mu \mathrm{g} / \mathrm{ml}, 1 \mu \mathrm{g} / \mathrm{ml}$ e $0,5 \mu \mathrm{g} / \mathrm{ml}$ e sonicadas, foram colocados em duplicata nas últimas fendas do Minifold II, deixando-se ainda duas fendas vazias, como controles negativos. As amostras de placa sem diluir foram distribuídas em porções de $10 \mu \mathrm{l}$ nas demais fendas. Feito o vácuo, a membrana de celulose foi removida do Minifold II e incubada em $100 \mathrm{ml}$ de TBS-BLOTTO por 1 hora, para bloquear os sítios não ocupados da nitrocelulose, evitando futuras ligações 
inespecíficas.

- Uso do Anticorpo Específico de Coelho

Terminado o bloqueio, a membrana foi lavada durante 5 minutos com TBST e incubada durante uma hora em $100 \mathrm{ml}$ da diluição do soro de coelho (para a P.gingivalis e P.nigrescens, 1:5000 e para o T. denticola, 1:15000) em TBS-TBLOTTO. A isso se seguiram três lavagens com TBS-T de 5 minutos de duração cada.

- Emprego do Soro de Cabra Anti-lgG de Coelho

A membrana foi incubada durante 1 hora com soro de cabra anti-lgG de coelho conjugado à fosfatase alcalina, diluído a 1:1000 em TBS-T-BLOTTO, seguindo-se as lavagens e revelação de forma idêntica à do ensaio anterior.

- Leitura

A leitura nos dois procedimentos foi visual e semiquantitativa, através da observação da intensidade de cor desenvolvida em cada fenda. As fendas receberam escores de 0 a 3 , onde 0 significa a ausência de cor; 1 - cor roxa mal detectável; 2 - intensidade intermediária e 3 - cor roxa de máxima intensidade. No que diz respeito às bactérias, o escore 1 representa uma concentração de pelo menos $2 \times 10^{4}$ UFC (unidades formadoras de colônias); o escore 2: de $2 \times 10^{4}$ a $3 \times 10^{5}$ UFC e o escore $3:>3 \times 10^{5}$ UFC. 
5 Resultados 


\section{RESULTADOS}

Nas TABELAS 1 e 2 são apresentados os dados que caracterizam os grupos experimental e controle quanto a sexo e idade. As médias \pm desviospadrão e medianas das idades (em meses) para os dois grupos foram respectivamente $66,67 \pm 3,74,68$ e $65,33 \pm 4,41,66$, sendo as porcentagens de meninos e meninas para os grupos experimental e controle, respectivamente de $70 \%$ e $30 \%$ e $44,44 \%$ e $55,56 \%$.

Os resultados relativos ao índice de placa e índice gengival dos grupos experimental e controle estão dispostos nas TABELAS 3 e 4 , sendo que, no grupo experimental (TABELA 3) foram considerados os 6 sítios (total) e realizada uma subdivisão para os 4 sítios posteriores e os 2 sítios anteriores, adjacentes à fissura.

Os valores médios, desvios-padrão e medianas das variáveis clínicas estudadas dos grupos experimental e controle encontram-se descritos na TABELA 5, ilustrando a FIGURA 8, os valores médios do IP e IG, para ambos os grupos.

A comparação das variáveis clínicas entre os grupos experimental e controle foi realizada através do Teste de Mann-Whitney, com nível de significância de 5\%. Foram comparados o IP e IG total (6 sítios) e de 4 sítios do grupo experimental com o IP e IG do grupo controle, verificando-se diferença estatisticamente significante entre o IG total e o IG de 4 sítios do grupo 
experimental e o IG do grupo controle $(p<0,05)$. Para os índices de placa não houve diferenças estatisticamente significantes entre os dois grupos (TABELA 6).

Utilizando-se o teste de Wilcoxon, foi realizado também, dentro do grupo experimental, a comparação entre o IP e IG separadamente dos sítios normais (4 sítios ) e da área da fissura (2 sítios), evidenciando-se diferença estatisticamente significante $(p<0,05)$ entre os IP de 4 e 2 sítios (TABELA 7).

As TABELAS 8 e 9 mostram o número e a porcentagem de crianças distribuídas de acordo com os graus de severidade do IP e IG. Para o grupo experimental verificou-se que, nas análises do IP total e IP de 4 sítios, a maioria apresentou índice de placa de grau moderado (escores entre 1,1 e 2,0 ). Em relação ao IP de 2 sítios, houve igualdade entre as porcentagens de graus moderados $(1,1-2,0)$ e altos $(2,1-3,0)$. Quanto ao IG, as análises de 2, 4 e 6 sítios mostraram apenas graus de severidade baixo e moderado, com pequena superioridade do grau baixo para o IG de 2 e 6 sítios e do grau moderado para o IG de 4 sítios. No grupo controle, a maioria das crianças apresentou índice de placa moderado e índice gengival de baixa severidade. As FIGURAS 9 e 10 representam a porcentagem de crianças de acordo com o grau de severidade do IP e do IG dos grupos experimental e controle.

Quando se comparou, através do teste do Qui-quadrado, a severidade do IP e IG entre os grupos experimental e controle e entre as áreas do grupo experimental (2, 4 e 6 sítios) não se constatou nenhuma diferença estatisticamente significante $(p<0,05)$ (TABELA 10). 
Os escores médios dos sítios subgengivais relativos ao conteúdo de carboidrato e das três bactérias selecionadas dos grupos experimental e controle encontram-se nas TABELAS 11 e 12, respectivamente. Para a obtenção desses escores médios, foram utilizados os resultados constantes dos ANEXOS E e F, nos quais os sítios 1 e 2 correspondem aos dentes superiores (55 e 65), os sítios 3 e 4 aos dentes inferiores ( 75 e 85) e, para o grupo experimental, os sítios 5 e 6 aos dentes adjacentes à fissura do rebordo alveolar.

As quantidades médias \pm desvios-padrão de carboidrato para os grupos experimental e controle foram respectivamente, $2,19 \pm 0,58$ e $2,55 \pm$ 0,40 .

A freqüência de deteç̧ão para a $P$. nigrescens foi de 16,67\% e $11,11 \%$, respectivamente para o grupo experimental e o grupo controle. Foi aplicado o Teste de Fisher para comparação, dando como resultado $p=0,709$, indicando, portanto, que não houve diferença estatisticamente significante entre os grupos. A P. gingivalis e o T. denticola não foram detectados.

Dos sítios positivos para a $P$. nigrescens no grupo experimental, três apresentaram escore 1 e dois o escore 2, enquanto no grupo controle, dois apresentaram o escore 1 e um o escore 3 , evidenciando predomínio de baixa concentração do microrganismo.

O número de sítios positivos, nas crianças que exibiram $P$. nigrescens pode ser visto na TABELA 13, mostrando o predomínio de infecção em sítios isolados. 
TABELA 1 - Características do grupo experimental quanto a sexo e idade.

\begin{tabular}{|c|c|c|c|}
\hline AMOSTRA \# & Iniciais & Sexo & Idade (meses) \\
\hline 1 & W.S.B. & $M$ & 60 \\
\hline 2 & C.M.B.M. & M & 60 \\
\hline 3 & L.S.F. & M & 62 \\
\hline 4 & M.N.S.S. & $\mathrm{F}$ & 62 \\
\hline 5 & L.J.O. & $\mathrm{F}$ & 62 \\
\hline 6 & M.N.S.M. & M & 62 \\
\hline 7 & R.S. & $M$ & 63 \\
\hline 8 & R.M.L.D. & $\mathrm{F}$ & 63 \\
\hline 9 & B.V.O. & M & 63 \\
\hline 10 & P.H.O. & $M$ & 63 \\
\hline 11 & A.J.B. & $M$ & 64 \\
\hline 12 & R.A.S. & $\mathrm{F}$ & 67 \\
\hline 13 & F.A.M. & $M$ & 67 \\
\hline 14 & F.H.C.L. & $M$ & 67 \\
\hline 15 & D.F.P. & $\mathrm{F}$ & 68 \\
\hline 16 & I.S.S. & $M$ & 68 \\
\hline 17 & M.V.A.P. & $M$ & 69 \\
\hline 18 & L.P.S. & $M$ & 69 \\
\hline 19 & I.B.M. & $\mathrm{F}$ & 69 \\
\hline 20 & M.W.R.S. & $M$ & 69 \\
\hline 21 & R.A P. & M & 69 \\
\hline 22 & G.S.G. & $M$ & 69 \\
\hline 23 & A.D.S. & M & 70 \\
\hline 24 & T.P.S. & $\mathrm{F}$ & 70 \\
\hline 25 & J.A.O.S. & M & 70 \\
\hline 26 & C.F.S. & $\mathrm{F}$ & 70 \\
\hline 27 & M.C.A.S. & $\mathrm{F}$ & 70 \\
\hline 28 & A.J.F. & M & 71 \\
\hline 29 & Y.S.F.A. & M & 72 \\
\hline 30 & M.M.D.C. & $M$ & 72 \\
\hline
\end{tabular}


TABELA 2 - Características do grupo controle quanto a sexo e idade.

\begin{tabular}{|c|c|c|c|}
\hline AMOSTRA \# & Iniciais & Sexo & Idade (meses) \\
\hline 1 & M.C.S. & $\mathrm{F}$ & 60 \\
\hline 2 & J.A.F. & $\mathrm{F}$ & 60 \\
\hline 3 & M.V.M. & $M$ & 60 \\
\hline 4 & C.V.M.O. & $M$ & 60 \\
\hline 5 & B.P.C. & $\mathrm{F}$ & 60 \\
\hline 6 & K.C.L. & $\mathrm{F}$ & 60 \\
\hline 7 & F.C. & $\mathrm{F}$ & 60 \\
\hline 8 & W.P.S. & M & 62 \\
\hline 9 & M.C.O. & $\mathrm{F}$ & 62 \\
\hline 10 & M.T.O. & M & 63 \\
\hline 11 & W.S. & M & 63 \\
\hline 12 & D.F. & $\mathrm{F}$ & 63 \\
\hline 13 & E.S.O. & $\mathrm{F}$ & 64 \\
\hline 14 & A.G.C. & $M$ & 66 \\
\hline 15 & D.M.F. & $\mathrm{F}$ & 66 \\
\hline 16 & M.D.S.C. & $M$ & 67 \\
\hline 17 & G.L.A. & $M$ & 67 \\
\hline 18 & N.B.M. & $\mathrm{F}$ & 67 \\
\hline 19 & L.G.G.C. & $\mathrm{F}$ & 68 \\
\hline 20 & A. M. & $\mathrm{F}$ & 69 \\
\hline 21 & D.C.B. & $\mathrm{F}$ & 69 \\
\hline 22 & R.M.M. & $F$ & 69 \\
\hline 23 & B.H.G. & $M$ & 71 \\
\hline 24 & M.F.S.C. & $M$ & 72 \\
\hline 25 & L.C.B.L. & $M$ & 72 \\
\hline 26 & J.P.S. & $M$ & 72 \\
\hline 27 & A.C.R. & $\mathrm{F}$ & 72 \\
\hline
\end{tabular}


TABELA 3 - Dados clínicos (índice de placa e índice gengival) do grupo experimental.

\begin{tabular}{|c|c|c|c|c|c|c|}
\hline \multirow[t]{2}{*}{ AMOSTRA } & \multicolumn{3}{|c|}{ IP } & \multicolumn{3}{|c|}{ IG } \\
\hline & total & 4 sítios & 2 sítios & total & 4 sítios & 2 sítios \\
\hline 1 & 2,3 & 2,1 & 2,8 & 1,1 & 1,2 & 1,0 \\
\hline 2 & 1,5 & 1,5 & 1,6 & 1,2 & 1,1 & 1,4 \\
\hline 3 & 2,0 & 1,8 & 2,6 & 1,0 & 1,1 & 1,0 \\
\hline 4 & 2,4 & 2,4 & 2,4 & 1,0 & 1,0 & 1,1 \\
\hline 5 & 1,5 & 1,5 & 1,5 & 1,1 & 1,1 & 1,0 \\
\hline 6 & 1,5 & 1,5 & 1,5 & 1,0 & 1,0 & 1,0 \\
\hline 7 & 1,1 & 1,0 & 1,3 & 1,0 & 1,0 & 1,0 \\
\hline 8 & 2,7 & 2,6 & 3,0 & 1,6 & 1,7 & 1,5 \\
\hline 9 & 2,0 & 2,1 & 1,8 & 1,0 & 1,0 & 1,0 \\
\hline 10 & 2,3 & 2,1 & 2,9 & 1,4 & 1,1 & 2,0 \\
\hline 11 & 1,4 & 1,4 & 1,3 & 1,2 & 1,2 & 1,1 \\
\hline 12 & 1,6 & 1,4 & 2,1 & 0,6 & 0,4 & 1,0 \\
\hline 13 & 2,0 & 1,7 & 2,5 & 0,9 & 0,9 & 1,0 \\
\hline 14 & 1,6 & 1,6 & 1,5 & 1,3 & 1,4 & 1,1 \\
\hline 15 & 2,2 & 1,9 & 2,8 & 1,0 & 1,0 & 1,1 \\
\hline 16 & 1,9 & 1,7 & 2,3 & 1,2 & 1,3 & 1,0 \\
\hline 17 & 2,1 & 2,0 & 2,6 & 1,0 & 0,9 & 1,0 \\
\hline 18 & 1,5 & 1,6 & 1,4 & 1,1 & 1,1 & 1,0 \\
\hline 19 & 2,0 & 1,7 & 2,8 & 0,7 & 0,6 & 1,0 \\
\hline 20 & 2,1 & 2,1 & 2,3 & 1,5 & 1,5 & 1,4 \\
\hline 21 & 2,1 & 1,9 & 2,5 & 1,1 & 1,1 & 1,1 \\
\hline 22 & 1,9 & 1,6 & 2,4 & 0,9 & 0,9 & 1,0 \\
\hline 23 & 1,5 & 1,5 & 1,4 & 0,9 & 1,1 & 0,5 \\
\hline 24 & 2,0 & 1,9 & 2,0 & 0,9 & 0,9 & 1,0 \\
\hline 25 & 1,7 & 1,4 & 2,3 & 1,1 & 1,0 & 1,4 \\
\hline 26 & 1,5 & 1,6 & 1,4 & 1,0 & 1,1 & 1,0 \\
\hline 27 & 1,2 & 1,1 & 1,4 & 0,7 & 0,5 & 1,0 \\
\hline 28 & 1,8 & 2,1 & 1,4 & 1,1 & 1,1 & 1,3 \\
\hline 29 & 1,8 & 2,1 & 1,4 & 0,8 & 0,9 & 0,8 \\
\hline 30 & 1,4 & 1,2 & 1,9 & 1,2 & 1,1 & 1,4 \\
\hline
\end{tabular}


TABELA 4 - Dados clínicos (índice de placa e índice gengival) do grupo controle.

\begin{tabular}{|c|c|c|}
\hline AMOSTRA & $\mathbf{I P}$ & IG \\
\hline 1 & 1,7 & 0,1 \\
\hline 2 & 1,9 & 1,1 \\
\hline 3 & 1,9 & 1,0 \\
\hline 4 & 0,9 & 0,2 \\
\hline 5 & 1,1 & 0,6 \\
\hline 6 & 1,2 & 0,4 \\
\hline 7 & 0,8 & 1,1 \\
\hline 8 & 2,3 & 1,0 \\
\hline 9 & 1,8 & 1,1 \\
\hline 10 & 2,3 & 1,2 \\
\hline 11 & 2,1 & 1,3 \\
\hline 12 & 1,8 & 1,4 \\
\hline 13 & 1,9 & 1,1 \\
\hline 14 & 1,8 & 1,1 \\
\hline 15 & 1,6 & 0,6 \\
\hline 16 & 1,6 & 0,9 \\
\hline 17 & 1,4 & 0,6 \\
\hline 18 & 1,8 & 0,8 \\
\hline 19 & 1,5 & 0,5 \\
\hline 20 & 1,4 & 0,7 \\
\hline 21 & 1,2 & 0,7 \\
\hline 22 & 1,5 & 0,8 \\
\hline 23 & 1,9 & 0,7 \\
\hline 24 & 1,9 & 0,8 \\
\hline 25 & 1,6 & 0,4 \\
\hline 26 & 1,3 & 0,6 \\
\hline 27 & 1,8 & 0,5 \\
\hline
\end{tabular}


TABELA 5 - Valores médios, desvios-padrão e medianas do IP e IG dos grupos experimental e controle.

\begin{tabular}{cccc}
\hline variáveis clínicas & média & dp & mediana \\
\hline \hline grupo experimental & & & \\
IP total & 1,82 & 0,38 & 1,85 \\
IP 4 sítios & 1,74 & 0,37 & 1,70 \\
IP 2 sítios & 2,04 & 0,58 & 2,05 \\
IG total & 1,05 & 0,22 & 1,00 \\
IG 4 sítios & 1,04 & 0,26 & 1,10 \\
IG 2 sítios & 1,11 & 0,26 & 1,00 \\
\hline \hline grupo controle & & & \\
IP total & 1,63 & 0,38 & 1,70 \\
IG total & 0,79 & 0,33 & 0,80 \\
\hline
\end{tabular}

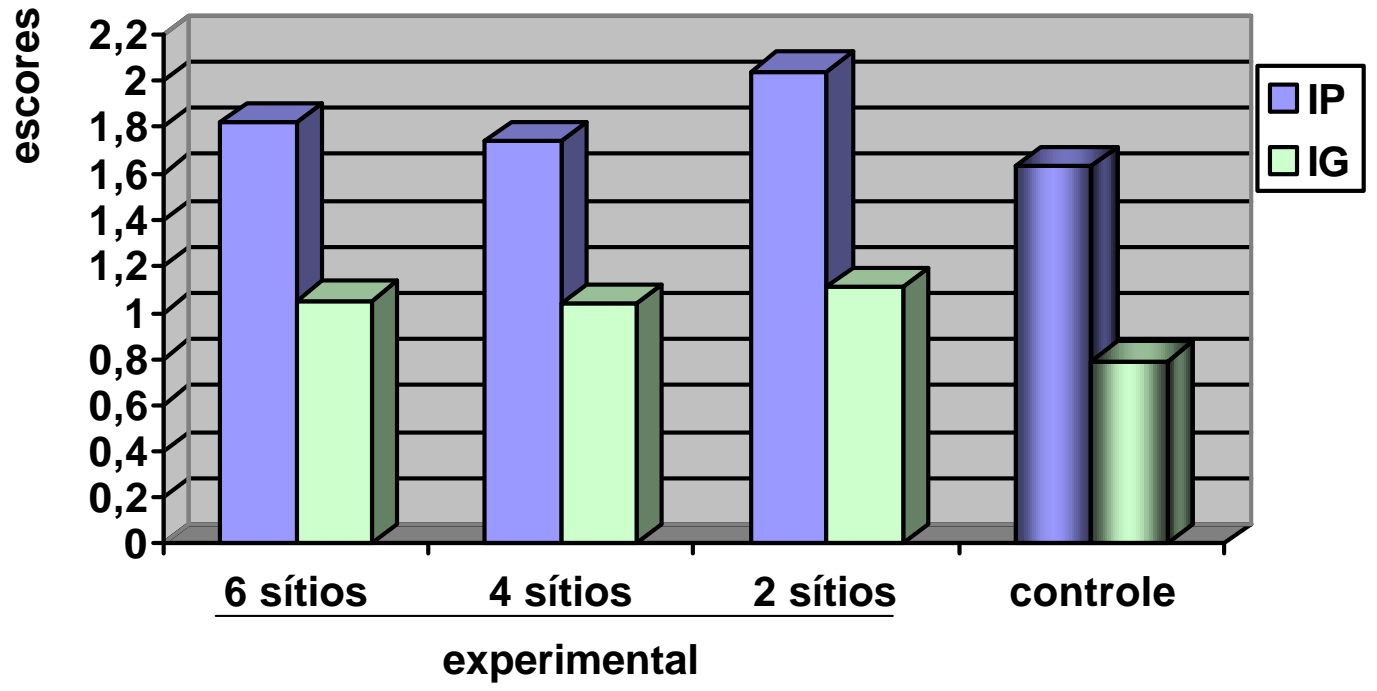

FIGURA 8 - Valores médios do IP e IG dos grupos experimental e controle. 
TABELA 6 - Comparação das variáveis clínicas entre os grupos experimental e controle (Teste de Mann-Whitney).

\begin{tabular}{ccccc}
\hline variável & $\begin{array}{c}\text { grupo experimental } \\
\text { posto médio }\end{array}$ & $\begin{array}{c}\text { grupo controle } \\
\text { posto médio }\end{array}$ & U & valor de $\mathbf{p}$ \\
\hline IP 6 sítios X IP & 32,6 & 25,1 & 298,5 & 0,09 \\
IP 4 sítios X IP & 30,8 & 27,0 & 352,0 & 0,40 \\
IG 6 sítios X IG & 35,1 & 22,2 & 221,5 & $0,003^{*}$ \\
IG 4 sítios X IG & 34,7 & 22,6 & 233,5 & $0,006^{*}$ \\
\hline
\end{tabular}

*diferença estatisticamente significante $(p<0,05)$

TABELA 7- Comparação das variáveis clínicas (IP e IG) entre sítios normais (4 sítios posteriores) e área da fissura (2 sítios anteriores) no grupo experimental (Teste de Wilcoxon).

\begin{tabular}{ccc}
\hline variável & $\mathbf{T}$ & valor de $\mathbf{p}$ \\
\hline IP 4 sítios X IP 2 sítios & 68,0 & $0,004^{*}$ \\
IG 4 sítios X IG 2 sítios & 138,5 & 0,35 \\
\hline * diferenca estatisticamente significante $(\boldsymbol{p}<0,05)$ &
\end{tabular}

* diferença estatisticamente significante $(p<0,05)$ 
TABELA 8 - Distribuição das crianças (\%) com escores de índices de placa baixos, moderados e altos.

\begin{tabular}{ccccc}
\hline escores & \multicolumn{3}{c}{ grupo experimental } & grupo controle \\
\cline { 2 - 4 } & IP 6 sítios & IP 4 sítios & IP 2 sítios & IP total \\
\hline \hline \multirow{2}{*}{$\mathbf{1}-\mathbf{1 , 0}$} & 0 & 1 & 0 & 2 \\
& $(0)$ & $(3,33)$ & $(0)$ & $(7,41)$ \\
$\mathbf{1 , 1}-\mathbf{2 , 0}$ & 22 & 21 & 15 & 22 \\
& $(73,33)$ & $(70,00)$ & $(50,00)$ & $(81,48)$ \\
$\mathbf{2 , 1}-\mathbf{3 , 0}$ & $(26,67)$ & $(26,67)$ & $(50,00)$ & 3 \\
\hline \hline & 30 & 30 & 30 & $(11,11)$ \\
\hline TOTAL & $(100)$ & $(100)$ & $(100)$ & $(100)$ \\
\hline
\end{tabular}

TABELA 9 - Distribuição das crianças (\%) com escores de índices gengivais baixos, moderados e altos.

\begin{tabular}{|c|c|c|c|c|}
\hline \multirow[t]{2}{*}{ Escores } & \multicolumn{3}{|c|}{ grupo experimental } & \multirow{2}{*}{$\begin{array}{c}\text { grupo controle } \\
\text { IG total }\end{array}$} \\
\hline & IG 6 sítios & IG 4 sítios & IG 2 sítios & \\
\hline & 16 & 14 & 18 & 19 \\
\hline \multirow[t]{2}{*}{$0,1-1,0$} & $(53,33)$ & $(46,67)$ & $(60,00)$ & $(70,37)$ \\
\hline & 14 & 16 & 12 & 8 \\
\hline \multirow[t]{2}{*}{$1,1-2,0$} & $(46,67)$ & $(53,33)$ & $(40,00)$ & $(29,63)$ \\
\hline & 0 & 0 & 0 & 0 \\
\hline \multirow[t]{2}{*}{$2,1-3,0$} & (0) & (0) & (0) & (0) \\
\hline & 30 & 30 & 30 & 27 \\
\hline TOTAL & $(100)$ & $(100)$ & $(100)$ & $(100)$ \\
\hline
\end{tabular}




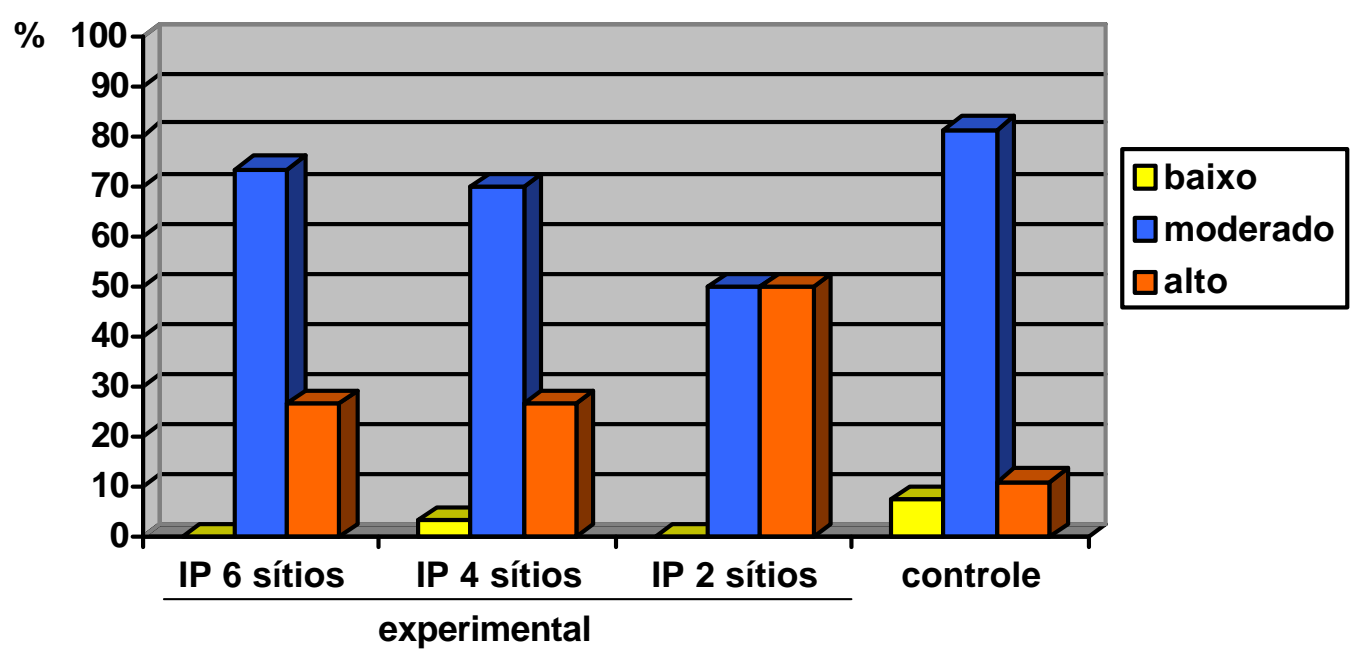

FIGURA 9 - Distribuição em porcentagem das crianças de acordo com os graus de severidade do índice de placa.

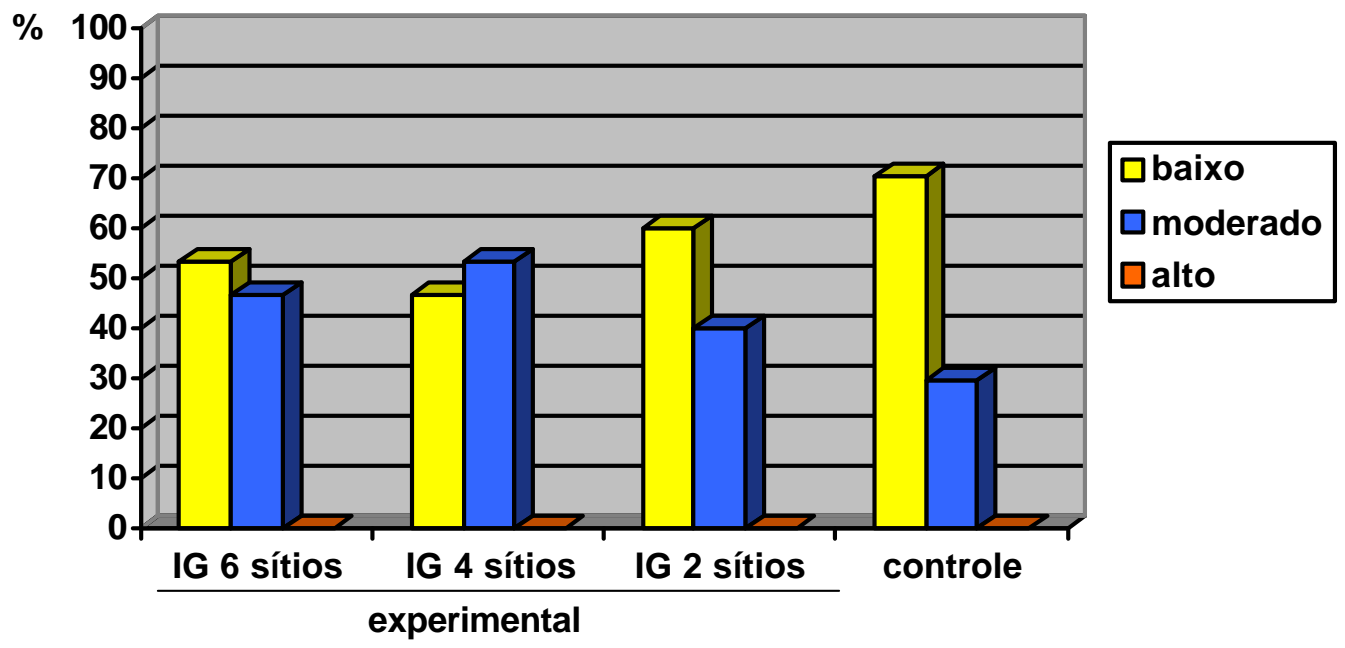

FIGURA 10 - Distribuição em porcentagem das crianças de acordo com os graus de severidade do índice gengival. 
TABELA 10 - Comparação dos graus de severidade do IP e IG entre os grupos experimental e controle e entre as áreas do grupo experimental (2, 4 e 6 sítios) (Teste do Qui-quadrado)*.

\begin{tabular}{cccccc}
\hline & \multicolumn{2}{c}{ IP } & \multicolumn{2}{c}{ IG } \\
& $\mathbf{x}^{2}$ & $\mathbf{p}$ & $\mathbf{x}^{2}$ & $\mathbf{p}$ \\
\hline $\mathbf{6}$ sítios X controle & 4,13 & 0,127 & 1,74 & 0,187 \\
$\mathbf{4}$ sítios X controle & 4,13 & 0,127 & 3,28 & 0,070 \\
$\mathbf{6}$ sítios X 4 sítios & 0 & 1 & 0,27 & 0,606 \\
$\mathbf{6}$ sítios X 2 sítios & 3,46 & 0,063 & 0,27 & 0,602 \\
$\mathbf{4}$ sítios X 2 sítios & 3,46 & 0,063 & 1,07 & 0,301 \\
\hline
\end{tabular}

* diferença estatisticamente significante $(p<0,05)$ 
TABELA 11 - Escores médios dos sítios subgengivais para o carboidrato e as três bactérias do grupo experimental.

\begin{tabular}{|c|c|c|c|c|}
\hline Amostra \# & Carboidrato & P. gingivalis & P. nigrescens & T. denticola \\
\hline 1 & 2,33 & 0 & 0 & 0 \\
\hline 2 & 2,50 & 0 & 0,17 & 0 \\
\hline 3 & 2,50 & 0 & 0,17 & 0 \\
\hline 4 & 2,83 & 0 & 0 & 0 \\
\hline 5 & 2,50 & 0 & 0 & 0 \\
\hline 6 & 2,33 & 0 & 0 & 0 \\
\hline 7 & 2,83 & 0 & 0 & 0 \\
\hline 8 & 3,00 & 0 & 0,17 & 0 \\
\hline 9 & 2,17 & 0 & 0 & 0 \\
\hline 10 & 2,00 & 0 & 0 & 0 \\
\hline 11 & 1,83 & 0 & 0 & 0 \\
\hline 12 & 2,50 & 0 & 0,33 & 0 \\
\hline 13 & 1,33 & 0 & 0 & 0 \\
\hline 14 & 2,50 & 0 & 0,33 & 0 \\
\hline 15 & 2,83 & 0 & 0 & 0 \\
\hline 16 & 1,67 & 0 & 0 & 0 \\
\hline 17 & 2,83 & 0 & 0 & 0 \\
\hline 18 & 1,00 & 0 & 0 & 0 \\
\hline 19 & 1,83 & 0 & 0 & 0 \\
\hline 20 & 2,83 & 0 & 0 & 0 \\
\hline 21 & 2,33 & 0 & 0 & 0 \\
\hline 22 & 2,17 & 0 & 0 & 0 \\
\hline 23 & 2,50 & 0 & 0 & 0 \\
\hline 24 & 3,00 & 0 & 0 & 0 \\
\hline 25 & 1,50 & 0 & 0 & 0 \\
\hline 26 & 1,50 & 0 & 0 & 0 \\
\hline 27 & 1,00 & 0 & 0 & 0 \\
\hline 28 & 2,17 & 0 & 0 & 0 \\
\hline 29 & 2,00 & 0 & 0 & 0 \\
\hline 30 & 1,50 & 0 & 0 & 0 \\
\hline
\end{tabular}


TABELA 12 - Escores médios dos sítios subgengivais para o carboidrato e as três bactérias do grupo controle.

\begin{tabular}{|c|c|c|c|c|}
\hline Amostra \# & Carboidrato & P. gingivalis & P.nigrescens & T.denticola \\
\hline 1 & 3,00 & 0 & 0 & 0 \\
\hline 2 & 2,50 & 0 & 0 & 0 \\
\hline 3 & 2,50 & 0 & 0 & 0 \\
\hline 4 & 2,50 & 0 & 0 & 0 \\
\hline 5 & 2,75 & 0 & 0 & 0 \\
\hline 6 & 2,25 & 0 & 0 & 0 \\
\hline 7 & 3,00 & 0 & 0 & 0 \\
\hline 8 & 2,75 & 0 & 0,75 & 0 \\
\hline 9 & 1,50 & 0 & 0 & 0 \\
\hline 10 & 3,00 & 0 & 0 & 0 \\
\hline 11 & 3,00 & 0 & 0,25 & 0 \\
\hline 12 & 3,00 & 0 & 0 & 0 \\
\hline 13 & 2,50 & 0 & 0 & 0 \\
\hline 14 & 2,50 & 0 & 0,25 & 0 \\
\hline 15 & 2,75 & 0 & 0 & 0 \\
\hline 16 & 2,00 & 0 & 0 & 0 \\
\hline 17 & 2,50 & 0 & 0 & 0 \\
\hline 18 & 2,75 & 0 & 0 & 0 \\
\hline 19 & 2,00 & 0 & 0 & 0 \\
\hline 20 & 2,50 & 0 & 0 & 0 \\
\hline 21 & 2,00 & 0 & 0 & 0 \\
\hline 22 & 3,00 & 0 & 0 & 0 \\
\hline 23 & 2,75 & 0 & 0 & 0 \\
\hline 24 & 2,50 & 0 & 0 & 0 \\
\hline 25 & 1,75 & 0 & 0 & 0 \\
\hline 26 & 2,75 & 0 & 0 & 0 \\
\hline 27 & 2,75 & 0 & 0 & 0 \\
\hline
\end{tabular}


TABELA 13 - Número de crianças positivas em 1, 2, 3, 4, 5 ou 6 sítios subgengivais para a $P$. nigrescens nos grupos experimental e controle.

\begin{tabular}{ccc}
$\begin{array}{c}\text { grupo } \\
\text { número de sítios }\end{array}$ & $\begin{array}{c}\text { experimental } \\
\mathrm{n}=30\end{array}$ & $\begin{array}{c}\text { controle } \\
\mathrm{n}=27\end{array}$ \\
\hline 1 & 3 & 2 \\
2 & 2 & 0 \\
3 & 0 & 1 \\
4 & 0 & 0 \\
5 & 0 & - \\
6 & 0 & - \\
\hline TOTAL & 5 & 3 \\
\hline
\end{tabular}


6 Discussão 


\section{DISCUSSÃo}

A fissura lábio-palatal é uma malformação congênita que acomete 1 a cada 650 nascimentos e acarreta aos seus portadores distúrbios estéticos, funcionais e emocionais. Sua reabilitação é longa e demanda o atendimento por várias especialidades durante muitos anos, com a preocupação maior de restabelecer a função e a estética prejudicadas, devolvendo-Ihes condições para uma vida física e emocionalmente saudável.

Os esforços da equipe de reabilitação são imensos, mas muito gratificantes, pois proporcionam aos portadores de fissura os meios necessários para sua recuperação. No entanto, a participação e o incentivo da família são imprescindíveis para que todas as etapas do tratamento possam ser adequadamente ultrapassadas, com o objetivo comum de reabilitar.

Quando presentes, a deformidade na região da fissura alveolar e a cicatriz cirúrgica do lábio operado constituem fatores de risco para as doenças bucais, uma vez que dificultam o controle adequado da placa dentária, somandose ainda o receio dos pais e dos pacientes para a higienização correta dessa área $11,20,75$.

O manejo odontológico de pacientes com fissura alveolar envolve também outros desafios. Os distúrbios no desenvolvimento dentário resultam em variações no número, morfologia, estrutura e irrupção dentária na área da fissura, sendo o incisivo lateral o dente mais comumente afetado ${ }^{80}$. Além disso, têm sido documentadas altas prevalência e severidade de má oclusão entre esses 
indivíduos, cujas manifestações podem iniciar-se na dentição decídua e exacerbar-se com o aumento da idade ${ }^{8,60,84,104}$. As irregularidades dentárias e dos segmentos maxilares, decorrentes da fissura, podem resultar em maior acúmulo de placa dentária com conseqüente aumento da freqüência de cárie e alterações periodontais nessa região, quando comparadas com pacientes não fissurados ${ }^{90}$.

É de fundamental importância a atuação do cirurgião-dentista em várias fases do tratamento, com o objetivo de prevenir as doenças bucais nestes indivíduos. Isso Ihes dará condição, através da preservação de uma dentição hígida, para que as cirurgias sejam realizadas em épocas oportunas; o desenvolvimento da fala não seja prejudicado por extrações dentárias precoces; a presença de dentes hígidos adjacentes à fissura ajude a manter tecido ósseo nessa região, favorecendo conseqüentemente o posicionamento dos segmentos maxilares e os dentes decíduos possam funcionar como suporte para os aparelhos ortodônticos utilizados na fase da dentadura mista. Ressalta-se ainda que a presença de dentes decíduos sadios é imprescindível para o desenvolvimento adequado do sistema estomatognático e manutenção de espaço para os dentes permanentes.

Portanto, neste estudo, procurou-se verificar se a saúde periodontal de crianças portadoras de fissura completa de lábio e palato, analisada sob os pontos de vista clínico e microbiológico, diferia da de crianças não fissuradas, devido aos fatores de risco que apresentam.

$\mathrm{Na}$ seleção da amostra optou-se pela escolha de apenas um tipo de fissura, a completa de lábio e palato unilateral, por entender-se que constitui a 
fissura mais abrangente anatômicamente e desta forma, com maiores conseqüências sobre os dentes e estruturas de suporte, além de ser, epidemiologicamente, a mais prevalente ${ }^{2}$.

Um outro detalhe em relação à amostra deve ser mencionado, uma vez que o número de indivíduos do sexo feminino e masculino diferiu nos grupos experimental e controle. No grupo controle foi possível um equilíbrio na distribuição dos sexos (44,44\% meninos e 55,56\% meninas); no entanto, no grupo experimental a porcentagem de meninos (70\%) foi maior do que a de meninas (30\%) (TABELAS 1 e 2).

Embora a literatura demonstre a ausência de diferenças em relação ao sexo para as variáveis clínicas e microbiológicas estudadas ${ }^{82}$, cabe aqui justificar que a colheita dos dados do grupo controle foi realizada em 3 dias em uma escola municipal de um núcleo habitacional e portanto, pôde ser adequadamente selecionada, enquanto a amostra do grupo experimental demorou aproximadamente 6 meses para ser colhida, sendo restrita a possibilidade de seleção equilibrada. Inicialmente foram convidados a participar, de forma voluntária, todos os pacientes portadores da fissura específica, na faixa etária analisada, residentes no estado de São Paulo e que preenchessem os prérequisitos para a seleção da amostra. As crianças deveriam apresentar apenas dentes decíduos e não terem tomado antibiótico nos últimos três meses, o que consistiu um fator de exclusão de várias delas, uma vez que apresentam maior predisposição à infecções do trato respiratório e auditivo do que aquelas sem fissuras, sendo freqüentemente submetidas às terapias com estes medicamentos. 
Além disso, existe também epidemiologicamente uma prevalência maior da fissura completa de lábio e palato no sexo masculino ${ }^{2}$, razão pela qual a amostra apresentou estas características, podendo o mesmo ser observado em outros estudos que avaliaram este tipo de fissura e que tiveram distribuições em relação aos sexos semelhantes às deste trabalho ${ }^{75,111}$.

Para a avaliação do grau de higiene bucal e do estado de saúde gengival foram utilizados os índices de placa e gengival de LÖE ${ }^{50}$ (1967) (TABELAS 3 e 4 ).

No grupo experimental os índices de placa para 6 sítios e 4 sítios apresentaram média \pm desvio padrão $(\mathrm{dp})$ de $1,82 \pm 0,38$ e 1,74 \pm 0,37, respectivamente, sendo que a maioria das crianças mostrou intensidade moderada de placa, para ambos os grupos (73,33\%). Na análise de 2 sítios verificou-se IP médio \pm dp igual a 2,04 $\pm 0,58$, sendo que o grau de intensidade dividiu-se igualmente entre moderado (50\%) e alto (50\%). Para o grupo controle, o IP médio $\pm \mathrm{dp}$ foi de 1,63 $\pm 0,38$ com a maioria apresentando quantidade moderada de placa (81,48\%) (TABELAS 5 e 8 e FIGURAS 8 e 9).

Os índices gengivais (IG) obtidos nos grupos experimental e controle demonstraram prevalência de sinais de inflamação gengival em 100\% dos casos (IG>0) (TABELAS 3 e 4). Para o grupo experimental, o IG médio \pm dp de 6 sítios foi de 1,05 \pm 0,22, de 4 sítios, 1,04 $\pm 0,26$ e de 2 sítios 1,11 $\pm 0,26$ (TABELA 5 e FIGURA 8). Quando se considerou a intensidade dos sinais verificou-se que, no grupo experimental, na avaliação de 6 ou 2 sítios, a maioria dos pacientes 
apresentou inflamação gengival de severidade baixa $(53,33 \%$ e $60 \%$, respectivamente), enquanto que, na análise de 4 sítios, houve superioridade do grau moderado (53,33\%) (TABELA 9 e FIGURA 10). No grupo controle, porém, observou-se que $70,37 \%$ das crianças apresentaram inflamação gengival de baixa severidade, com valor do IG médio \pm dp igual a 0,79 0,33 (TABELAS 5 e 9 e FIGURAS 8 e 10).

A literatura demonstra que a prevalência de gengivite em crianças, em diferentes faixas etárias, classes sociais e etnias, principalmente em brasileiros, é considerada alta, variando de $84,3 \%$ a $100 \% 17,18,36,55,101,109,118$, embora a maioria dos trabalhos tenha encontrado manifestação de severidade baixa 17, 1, 101, ${ }^{118}$ à moderada ${ }^{18,55}$; assim como ocorreu neste estudo.

Os índices de placa e gengivite relatados pelos diferentes autores em crianças não fissuradas dessa faixa etária são variados, desde índices médios de placa de 0,66 $\pm 0,24$ ou gengival de 0,66 $\pm 0,29$, em crianças australianas ${ }^{101}$, ou IP médio de 1,02 $\pm 0,48$ e IG médio de 0,36 \pm 0,39 na consulta inicial de uma avaliação longitudinal de 3 anos em crianças israelenses ${ }^{77}$, até médias de IP de 1,6 \pm 0,4 e IG de 1,0 \pm 0,3 em crianças japonesas com gengivite ${ }^{74}$. Estes últimos resultados foram mais próximos ao deste trabalho.

Frise-se que, neste estudo, para a obtenção dos índices de placa e gengival foram avaliadas somente as unidades dentárias a serem amostradas microbiologicamente, o que é comum neste tipo de pesquisa ${ }^{64,74,82,113}$, enquanto os trabalhos de cunho epidemiológico relacionados, em sua maioria fazem a análise da boca toda 17, 18, 35, 109, 118. HUGOSON; KOCH; RYLANDER ${ }^{35}$, em estudo de prevalência de gengivite observaram maiores escores de placa e 
inflamação gengival nas faces vestibulares dos segundos molares superiores e lingual dos segundos molares inferiores, justamente as áreas amostradas para exame microbiológico neste trabalho. Dessa forma, os índices médios de placa e de inflamação gengival observados, tanto na região anterior como na região posterior, podem refletir as piores condições para ambas regiões avaliadas (área da fissura e região posterior).

Além das limitações técnicas, deve-se acentuar que a análise comparativa dos índices de placa e gengival em diferentes populações, com diferentes hábitos e diferentes classes sociais é difícil de ser estabelecida, conhecendo-se a influência de todos estes aspectos na qualidade do controle de placa e conseqüentemente na saúde gengival. Portanto, neste estudo optou-se pela utilização de um grupo controle de crianças não fissuradas para comparação, que apresentassem características sócio-econômicas semelhantes às do grupo experimental, ou seja, de crianças pertencentes às classes sociais baixas ou médias inferiores.

Os resultados do presente estudo demonstraram índices de inflamação gengival significantemente maiores nas crianças portadoras de fissura completa de lábio e palato unilateral em comparação às crianças não fissuradas $(p<0,05)$, mas ausência de diferença estatística nos índices de placa entre esses dois grupos (TABELA 6). Este resultado demonstra que o controle de placa dentária é um aspecto crítico em crianças desta faixa etária, portadoras de fissura ou não, pois, quando se analisa o grau de severidade dos escores do IP observa-se que a maioria das crianças apresenta severidade moderada e alta, com apenas poucas crianças do grupo controle apresentando grau baixo (TABELA 8 e FIGURA 9). No 
entanto, a análise dos graus de severidade da inflamação gengival demonstrou apenas manifestações de grau leve e moderado, para ambos os grupos (TABELA 9 e FIGURA 10).

$\mathrm{Na}$ análise das regiões bucais do grupo experimental verificou-se maior acúmulo de placa na região anterior superior (IP de 2 sítios) em comparação com a região posterior (IP de 4 sítios), com diferenças estatisticamente significantes entre eles $(p<0,05)$ (TABELA 7). Estas observações foram comprovadas em outros estudos que verificaram, em crianças portadoras de fissura, maior acúmulo de placa nesta região como conseqüência de anomalias dentárias, colapso dos segmentos maxilares e fibrose cicatricial resultante do reparo cirúrgico do lábio, que limitam ou dificultam o acesso para uma higiene bucal satisfatória 11, 20, 75 . Todavia, no presente estudo, o maior acúmulo de placa não se traduziu em maior inflamação gengival na região anterior superior de portadores de fissura, conforme demonstrado pela ausência de diferença estatisticamente significante entre o IG de 2 sítios e o IG de 4 sítios, o que contradiz os resultados de outros autores ${ }^{20,75}$.

A diferença observada quando utilizadas as médias dos IP (TABELA 7) quase se confirmou estatisticamente, quando empregadas as faixas indicadoras do grau de severidade, com $\mathrm{p}=0,06$ (TABELA 10).

As investigações disponíveis na literatura sobre a saúde bucal de crianças portadoras de fissura lábio palatal, de modo geral, avaliaram a presença de cárie dentária, presença de placa/nível de higiene bucal e grau de inflamação gengival ${ }^{11,20,75,111}$ (vide FIGURA 1). No entanto, existe uma grande variedade metodológica nessas pesquisas nas quais, por vezes, todos os tipos de fissuras 
são agrupados e considerados entidades patológicas similares, sem levar em consideração os aspectos mais contundentes das fissuras completas de lábio e palato, que podem influir significantemente nos resultados.

Embora não fosse objetivo deste estudo a avaliação da cárie dentária, alguns comentários sobre esse assunto merecem ser tecidos, uma vez que os trabalhos citados apresentaram diversas formas de análises, ora comparando portadores de vários tipos de fissuras com indivíduos não fissurados ${ }^{11,} 20$, constatando maior prevalência de cárie em portadores de fissura; ora comparando diferentes tipos de fissura entre si ${ }^{20,75}$, verificando não haver diferenças significantes nos índices de cárie entre eles; ora realizando apenas um levantamento da presença ou ausência de cárie em indivíduos com fissura completa de lábio e palato unilateral e encontrando uma porcentagem de $45 \%$ de crianças com cárie neste grupo de pacientes ${ }^{111}$.

Quanto à higiene bucal, as investigações também apresentaram várias metodologias para a avaliação da presença de placa bacteriana. Dois estudos foram realizados sem a utilização de índices de placa, sendo a análise de sua presença feita de forma subjetiva. O primeiro comparou crianças portadoras de diferentes tipos de fissura com crianças não fissuradas, na faixa etária de 5-6 anos de idade, e encontrou higiene bucal mais precária nos portadores de fissura $^{20}$, e o outro apenas constatou que $66 \%$ de um grupo de crianças portadoras de fissura completa de lábio e palato unilateral (idades entre 5 e 9 anos) apresentaram higiene bucal precária ${ }^{111}$.

Somente um terceiro estudo, realizado por PAUL; BRANDT ${ }^{75}$ analisou objetivamente a presença de placa, através da utilização de índice. No entanto, os 
autores avaliaram somente pacientes portadores de fissura, de vários tipos, comparando as regiões da boca e os tipos de fissura entre si. Verificaram que o IP médio foi maior no grupo com fissura completa de lábio e palato quando comparado aos índices das fissuras isoladas de lábio ou palato, maior no segmento anterior do que no segmento posterior e maior no arco superior do que no inferior. Os índices médios de placa e gengival foram de $1,1 \pm 0,8$ e de $0,4 \pm$ 0,05, respectivamente, e inferiores aos do presente estudo. Entretanto, a comparação com esses resultados deve ser feita com ressalvas uma vez que os índices médios por eles referidos englobaram inclusive fissuras isoladas de lábio ou palato, que apresentam menor predisposição ao acúmulo de placa do que as fissuras completas de lábio e palato. Além disso, na pesquisa foi avaliada uma larga faixa etária (dos 3 aos 18 anos) e, embora a amostra tenha sido dividida em 3 grupos etários (3-5, 6-12 e 13-18 anos), não foram mencionados resultados específicos do IP e do IG para a dentição decídua.

Os estudos sobre a saúde gengival de crianças portadoras de fissura, com ou sem a utilização de índices, são também unânimes em afirmar que as mesmas apresentam maior ocorrência de inflamação gengival do que os indivíduos não fissurados ${ }^{11,20}$, principalmente na região anterior superior. A pesquisa de PAUL; BRANDT ${ }^{75}$, que avaliou diferentes regiões bucais de portadores de vários tipos de fissura, evidenciou pior saúde gengival para o grupo de fissura de lábio e palato, comparada a do grupo de fissura de palato isolada, sendo que nas fissuras uni e bilaterais (sem mencionar se completas ou incompletas) o segmento anterior apresentou pior condição gengival do que os posteriores. 
Como visto, são poucos os estudos que avaliaram a higiene bucal e a saúde gengival de crianças portadoras de fissura, provavelmente porque crianças situadas nas faixas etárias mais baixas, portadoras de fissuras ou não, são consideradas de menor risco às alterações dos tecidos gengivais.

A literatura também relata que, em pacientes adultos jovens portadores de fissura de lábio e palato, os dentes adjacentes à fissura parecem ser de maior risco à gengivite, mas não à doença periodontal, quando comparados com dentes controles do lado não fissurado ${ }^{108}$.

A comparação de dados entre sítios fissurados e não fissurados em pacientes adultos portadores de fissura completa de lábio e palato uni ou bilateral indicou que as características anatômicas da fissura não foram os únicos fatores decisivos ao desenvolvimento de problemas periodontais, mas constatou a participação de fatores adicionais como próteses ou aparelhos ortodônticos utilizados por longo período de tempo ${ }^{12,13,14,79}$.

A presença de sinais clínicos de doença periodontal nos dentes adjacentes à fissura manifestou-se através da presença de um tecido conjuntivo de inserção mais extenso, sugerindo perda de inserção e de menor altura da crista óssea alveolar, observada radiograficamente ${ }^{12,13}$. Todavia, as características clínicas do tecido periodontal não predispuseram os pacientes à maior destruição periodontal, induzida por infecção bacteriana, quando comparados com sítios que apresentam inserção fibrosa supra-alveolar com altura normal ${ }^{13}$. 
Dois estudos recentes realizados por um mesmo grupo de autores com pacientes adultos portadores de fissura de lábio e palato unilateral e bilateral confirmaram que estes indivíduos apresentavam higiene bucal mais precária e maior prevalência de gengivite quando comparados com portadores de fissura isolada de palato (grupo controle). Contradizendo os resultados de estudos anteriores relataram também maior predisposição à doença periodontal profunda no dente adjacente à fissura, o que não ocorreu com os pacientes com fissura isolada de palato, que exibiram condições periodontais similares às observadas na população em geral ${ }^{27,87}$.

Estudos epidemiológicos, clínicos e histológicos indicam que existe uma relação entre a idade e a tendência ao desenvolvimento da gengivite, mostrando que, sob condições comparáveis de placa, a severidade da gengivite é mais intensa em adultos do que em crianças.

Alguns estudos clínicos aplicaram o mesmo modelo de gengivite experimental de LÖE; THEILADE; JENSEN ${ }^{51}$, em crianças com idade pré-escolar e observaram somente sinais insignificantes de gengivite durante o período experimental, apesar do aumento progressivo da placa ${ }^{53,56,68}$, demonstrando que o risco de desenvolver formas severas de gengivite é baixo em pré-escolares saudáveis. Quando da avaliação da gengivite de ocorrência natural também se constatou que, para acúmulos de placa equivalentes, a gengivite é mais intensa em adultos que em crianças ${ }^{58,65}$. 
Segundo MATSSON ${ }^{57}$, as razões para as diferenças relacionadas à idade na suscetibilidade à gengivite ainda não são completamente conhecidas. As diferenças no sistema de defesa imune ou aquelas morfológicas ou qualitativas na composição da placa bacteriana, poderiam explicar a variação na propensão do tecido gengival reagir com inflamação nas diferentes idades. Acrescenta-se ainda a maturação psicológica e o desenvolvimento da habilidade motora durante o crescimento da criança, fatores estes que têm um grande impacto na sua motivação e habilidade para o domínio de técnicas de higiene bucal.

Durante a infância, o sistema imune ainda está imaturo e conseqüentemente, a intensidade ou qualidade da resposta não é a mesma do adulto. Estudo imunohistológico identificou diferença qualitativa na resposta celular inflamatória relacionada à idade, constatando que a lesão de gengivite em crianças é dominada por linfócitos T e a lesão em adultos por linfócitos $B{ }^{119}$.

Dentre as diferenças morfológicas citadas entre os tecidos gengivais dos dentes decíduos e permanentes, uma é a localização do infiltrado inflamatório que, na dentição permanente, localiza-se na porção coronária da gengiva livre, enquanto que na dentição decídua ocupa uma porção mais estreita ao longo do epitélio gengival. Outra é que, o epitélio juncional da gengiva do dente decíduo é mais espesso do que o do dente permanente, podendo apresentar uma permeabilidade reduzida às toxinas bacterianas ${ }^{10}$, e uma terceira é a grande vascularização no tecido conjuntivo de crianças, que pode favorecer a resistência contra infecções bacterianas ${ }^{57}$.

Em relação à microbiota, são evidentes e significantes diferenças na presença e proporção de microrganismos na placa dentária de crianças, 
adolescentes e adultos ${ }^{21,65,66,68,74}$, uma vez que sua composição depende de um complexo de princípios ecológicos (características do hospedeiro, dieta, adesão bacteriana, transmissibilidade bacteriana etc...) que mudam com 0 crescimento e amadurecimento do indivíduo ${ }^{99}$.

Existe também a sugestão que fatores genéticos e/ou ambientais, como a qualidade da água de abastecimento e o número de indivíduos infectados na comunidade, estresse psicológico e doenças infecciosas predisponham os indivíduos à colonização bucal por patógenos periodontais ${ }^{112}$.

Uma vez que a prevalência e a severidade da doença periodontal têm uma grande variação entre os indivíduos, um importante aspecto para sua prevenção é a identificação dos indivíduos de risco, sendo um dos indicadores de risco a presença subgengival de patógenos periodontais ${ }^{112}$.

Como a doença periodontal em crianças normalmente se restringe à gengivite, o estudo de sua microbiota, até bem pouco tempo, mereceu pouca atenção dos pesquisadores, preocupados mais em descobrir a constituição de sítios sadios e sítios periodontalmente doentes em adultos. À medida, porém, que algumas espécies foram sendo apontadas como periodontopáticas, surgiram outras indagações, como o momento de aquisição desses microrganismos e, indo além, as fontes de infecção e transmissão, cujas respostas dependem da análise dos indivíduos mais jovens ${ }^{82}$.

A colonização bacteriana pode ocorrer facilmente num ecossistema bucal imaturo como o das crianças, pelo fato de não estarem totalmente desenvolvidos os processos reguladores. Por outro lado, a colonização não ocorre se não houver um ecossistema adequado para a aderência e 
sobrevivência das bactérias que dependem das características ecológicas dos dentes ou tecidos periodontais ${ }^{99}$.

Este trabalho, dentro da linha de pesquisa que procura demonstrar o momento de aquisição dos periodontopatógenos potenciais em condições normais e em situações de risco, contribui para ampliar o conhecimento sobre as relações entre eles, o que é útil para a compreensão da biologia da placa subgengival e planejamento de estratégias para o seu controle.

Desde a observação inicial da microbiota subgengival por Leeuwenhoek em 1683, as investigações sobre esse ecossistema demonstram que as placas subgengivais são compreendidas por uma complexa mistura de espécies bacterianas, tendo-se estimado que 400 ou mais espécies residem nessa área. Mesmo que o exame pareça não demonstrar qualquer ordem nessa composição, avaliações culturais, imunológicas ou por sondas de DNA demonstram que certas espécies freqüentemente ocorrem juntas nas amostras. É o caso da P.gingivalis e o B.forsythus, a P.gingivalis e o T.denticola e a P.intermedia e o Fusobacterium nucleatum.

A ordenação da comunidade é um procedimento que tenta indicar espécies intimamente relacionadas dentro de uma comunidade e depois demonstrar a afinidade entre diferentes comunidades dentro do ecossistema de interesse. Em trabalho de SOCRANSKY et al. ${ }^{100}$, os autores tentaram fazer a ordenação de comunidades para examinar as relações entre espécies bacterianas em amostras de placa subgengival e relacionar os complexos à parâmetros clínicos de doença 
periodontal. Ao conseguir estabelecer uma relação notável de um grupo de 3 bactérias (B.forsythus, P.gingivalis e T.denticola) com parâmetros clínicos, bem como a íntima associação daquele grupo com um segundo complexo formado por subspécies de F.nucleatum/periodonticum, Prevotella intermedia, Prevotella nigrescens e Peptostreptococcus micros, os autores sugerem que o conhecimento das associações entre as espécies subgengivais pode ser usado para guiar a terapia periodontal. O reconhecimento de que um complexo de espécies inter-relacionadas, como o formado pelas três bactérias, sugere que os tratamentos que afetem uma dessas espécies podem influenciar a colonização das outras espécies do grupo. Além disso, pode-se especular que ao se alterar o segundo grupo, poderia ser evitada a subseqüente colonização das bactérias do primeiro grupo, o que dá ao profissional uma segunda escolha para o controle desses microrganismos.

Essa relação notável entre a P.gingivalis e o T.denticola, não foi detectada apenas por SOCRANSKY et al. ${ }^{100}$. Parece que o T.denticola precisa da presença da P.gingivalis. Fortes associações entre ambos foram detectadas também por SIMONSON et al. ${ }^{91}$; SIMONSON et al. ${ }^{92}$; PEDERSON et al. ${ }^{76}$. Coincidentemente, ambas as bactérias não foram detectadas no presente trabalho.

Até a década de 70, bacilos negros, relatados como B.melaninogenicus, na faixa dos 3 aos 8 anos, ou não foram detectados ${ }^{40}$, ou estiveram presentes, em porcentagens de até $40,0 \%^{3,6,70}$, sendo que, em índios guatemaltecos, a prevalência foi semelhante a de outras idades ${ }^{70}$. 
Quando usadas técnicas que já propiciavam uma diferenciação das subspécies ou espécies desses microrganismos, ficou claro que a taxa de detecção das espécies pesquisadas não era a mesma.

Através da cultura microbiológica , a Porphyromonas gingivalis não foi vista em bebês ${ }^{24,43,48,78}$, nem na dentição decídua ${ }^{24,43,45,65,6874,78,93,126}$, ou estava apenas minimamente presente ${ }^{25}$, talvez em decorrência das condições do indivíduo, uma vez que SAWYER et al. ${ }^{86}$ puderam observar a P.melaninogenica e a P.gingivalis em mais de $75 \%$ de crianças africanas subnutridas de 1 a 5 anos, mas em nenhuma criança normal.

De outro lado, há discrepância quanto à idade em que a bactéria é encontrada pela primeira vez no sulco gengival, com autores indicando a detecção a partir dos 9 anos ${ }^{7}$ ou do período circumpubertal ${ }^{73}$, ou raramente aos 15 anos $^{93}$, enquanto outros não a detectaram nem aos $11^{113}$, nem aos 15 anos ${ }^{78}$, ou mesmo na faixa adulta com periodonto normal ${ }^{59,74}$. ROBERT; MOUTON ${ }^{81}$, diferindo dos demais, encontraram a P.gingivalis em 14,6\% das pessoas entre 6 e 15 anos por eles pesquisadas.

Quando outras técnicas foram usadas, porém, os resultados obtidos foram diferentes. A imunofluorescência indireta mostrou uma prevalência de $68,3 \%$ da P.gingivalis, contra $14,6 \%$ obtida pela cultura, em crianças de $6-15$ anos ${ }^{81}$ e de $41 \%$ contra 2,4\%, em crianças de 1-16 anos ${ }^{93}$. Técnicas de biologia molecular revelaram porcentagens de detecção de $14 \%$ a 50\%, em crianças cujas idades variavam de 1 a 14 anos, com a maior positividade sendo observada nos indivíduos com evidência de inflamação gengival $1,4,41,61$, sendo a bactéria encontrada até mesmo em criança com menos de 1 ano de idade ${ }^{61}$. Pela técnica 
de ELISA a $P$. gingivalis foi observada em $80 \%$ crianças com idades entre 2 e 18 anos por WATSON et al. ${ }^{121}$. A não detecção da $P$. gingivalis no presente trabalho coincide com os dados da cultura ${ }^{24,43,45,74,78,86,126}$ e também com os de $\operatorname{ROSA}^{82}$, que utilizou a mesma técnica.

Se a não detecção nas crianças pesquisadas resultou da ausência do microrganismo ou da presença abaixo do limiar do SIB, só poderá ser respondido pelo uso de uma técnica mais sensível.

Os dados sorológicos mostram-se também contraditórios. Se, de um lado, MOUTON et al. ${ }^{71}$ confirmam os dados bacteriológicos, revelando que poucas crianças entre 6 meses e 6 anos apresentam anticorpos IgG para a $P$. gingivalis, em trabalho posterior o mesmo grupo ${ }^{93}$, usando dois diferentes antígenos de uma cepa de referência desse microrganismo, desmentem esses resultados apontando presença de anticorpos IgG séricos em cerca de 100\% das crianças entre 1 e 16 anos.

O emprego dos dois métodos (bacteriológico e imunológico) indica uma correlação positiva entre o número de células de P.gingivalis cultivadas de amostras subgengivais e os níveis de anticorpos séricos para o microrganismo ${ }^{74}$. NAKAGAWA et al. ${ }^{74}$, não encontraram aumento significante de anticorpos antiP.gingivalis em grupos periodontalmente sadios, de 3 a 28 anos de idade, dos quais não isolaram o microrganismo. A ausência da P.gingivalis nesses grupos foi consistente com a hipótese de que a colonização induz a resposta anticórpica no soro. 
Discussão

A distinção entre P.intermedia e P.nigrescens, proposta em $1992{ }^{89}$, dificulta a interpretação dos trabalhos (a maioria) que não a levaram em conta, pois a bactéria citada pelos autores como P.intermedia, tanto pode ser a mesma, como a P.nigrescens, daí a referência à $P$.intermedia/nigrescens nesta Discussão, sempre que houver essa possibilidade, para mostrar a ambigüidade das informações, reservando-se as designações P.intermedia e P.nigrescens, para os microrganismos realmente identificados como tais. Saliente-se a importância de novos estudos que discriminem as espécies nas amostras de placa subgengival para acentuar a relação de uma ou ambas espécies à patogênese da doença periodontal ${ }^{33}$.

A Prevotella intermedia/nigrescens é mais facilmente encontrada em crianças que a $P$.gingivalis, por qualquer método empregado ${ }^{1,41,78}$. Há relato de detecção já a partir do primeiro mês de vida ${ }^{24}$, e o seu isolamento de $7 \%$ dos bebês entre 1-7 meses de idade ${ }^{43}$, com a prevalência aumentando desde $10 \%$ dos edêntulos até $67 \%$ nos dentados ${ }^{45}$. Para KÖNÖNEN et al. ${ }^{48}$, trata-se de um colonizador tardio, entre as várias espécies anaeróbias que colonizam a cavidade bucal no primeiro ano de vida, muito embora haja autores que somente a isolaram em crianças a partir dos 3 anos de idade ${ }^{78}$.

Na dentição decídua, a taxa de isolamento da P.intermedia/nigrescens foi de $21 \%{ }^{25}$. Técnicas de biologia molecular mostraram porcentagens de detecção na dentição decídua e mista de $18 \%{ }^{4}$. Ainda na dentição decídua, porcentagens maiores foram relatadas por outros autores, tanto na ausência como na presença de inflamação, $57 \%$ e $70 \%$ segundo KISBY et al. ${ }^{41}$ e, $44 \%$ e $61,7 \%$ segundo ABRAHAM et al. ${ }^{1}$, respectivamente. Este microrganismo é encontrado, portanto, 
desde a infância, aumentando no período circumpubertal ${ }^{73}$, sendo o mais prevalente dos bacilos negros, aos 11 anos ${ }^{113}$.

Os resultados de pesquisas que avaliaram uma ou ambas as espécies individualmente parecem apontar para a presença mais precoce da P.nigrescens. Nesta avaliação a $P$. nigrescens foi detectada em 16,67\% e $11,11 \%$ das crianças dos grupos experimental e controle, respectivamente, com poucos sítios colonizados e escores de detecção variados (TABELAS 11, 12 e 13). ROSA ${ }^{82}$, que investigou a P.nigrescens na faixa dos 3-6 anos de idade pelo SIB, detectoua em $23,7 \%$ das crianças, observando, porém, correlação negativa com a idade.

MÄTTÖ et al. ${ }^{59}$, que procuraram tanto a P.intermedia como a P.nigrescens, em crianças entre 2-3 anos, detectaram somente a última em 4/6 crianças. Também CONRADS et al. ${ }^{16}$, na pesquisa de ambas, só detectaram a P.nigrescens, desde em pré-escolares até adultos jovens com periodonto normal. Para autores que encontraram as duas bactérias, a P.nigrescens exibiu maior prevalência, sendo observada em 1/8 crianças na faixa de 0-4 anos de idade e em 5/6 crianças na faixa de 5-10 anos, contra a ocorrência de P.intermedia em 3/6 crianças na faixa de 5-10 anos, segundo VAN STEENBERGEN et al. ${ }^{116}$, o mesmo ocorrendo com FUKUI et al. ${ }^{26}$, que detectaram a primeira em $5 / 6$ crianças e a última em 3/6 crianças com idades entre 4 e 15 anos. Todos esses autores utilizaram técnicas de biologia molecular.

O encontro mais freqüente da P.nigrescens nos indivíduos mais jovens parece dar suporte aos autores que sugerem que a P.intermedia estaria mais provavelmente associada com a periodontite e a P.nigrescens com a gengiva sadia $19,29,31,43,54,59,65,69,105,116$. Mesmo assim, é cedo para fazer-se maiores 
ilações sobre a P.nigrescens, considerando que também já foi detectada em adultos com periodontite avançada ${ }^{59}$ e com gengivite ${ }^{105}$. Por enquanto, os dados ainda são controvertidos. Para TEANPAISAN; DOUGLAS; WALSH ${ }^{107}$, que encontraram as duas espécies em adultos periodontalmente sadios e também em portadores de periodontite do adulto, com freqüência semelhante em sítios sadios e sítios ativos, as duas espécies são comensais comuns, que podem agir como patógenos oportunistas. Situação diferente daquela da P.gingivalis, não encontrada em adulto sadios, somente em sítios ativos, sendo apontada como patógeno potencial com o que concordam, em parte, MAEDA et al. ${ }^{54}$, que detectaram a P.gingivalis somente em sítios ativos; a P.intermedia, como o bacilo negro predominante em indivíduos periodontalmente sadios e sítios ativos, e a P.nigrescens, o bacilo negro predominante em indivíduos periodontalmente sadios.

NAKAGAWA et al. $^{73}$ verificaram que a P.intermedia/nigrescens correlaciona-se significantemente com o índice de placa e o índice gengival em todas as faixas etárias (infância, escolar, circumpubertal). ROSA ${ }^{82}$ observou correlação positiva entre a P.nigrescens e o índice gengival, mas não com o índice de placa, na faixa de 3-6 anos. No presente trabalho, a pequena porcentagem de positividade não permitiu estabelecer qualquer correlação com os indicadores clínicos.

Alguns relatos indicam que a P.intermedia/nigrescens pode ser parte importante da microbiota associada à doença periodontal precoce. Em estudo de MISHKIN et al. ${ }^{63}$, o microrganismo constituiu $8 \%$ da microbiota cultivável de lesão de periodontite pré-puberdade, em criança de 7 anos. Em outras duas crianças 
com 7 e 9 anos de idade e periodontite severa, a bactéria representou 12,5\% e $6,0 \%$ da microbiota ${ }^{123}$. Também SWEENEY et al. ${ }^{103}$ associaram-na significantemente com a periodontite pré-puberdade, sugerindo que possa ser patógeno importante em muitos casos desse quadro clínico. Essas observações indicam a necessidade de novas pesquisas que definam a (s) espécie (s) realmente envolvida (s): P.intermedia, P.nigrescens ou P.pallens.

Qual seria o significado do encontro da P.nigrescens nas crianças estudadas, caso se configure num indicador de risco para desenvolvimento da doença periodontal? A simples presença de patógenos não significa que um indivíduo desenvolverá a periodontite. Para iniciar ou causar a progressão da doença num sítio específico, num dado momento, o hospedeiro tem que ser suscetível, deve haver um número suficiente do patógeno virulento, o ambiente local deve levar à expressão dos fatores de virulência do mesmo e as espécies bacterianas coexistentes devem ser incapazes de inibir sua atividade ${ }^{33}$.

O último microrganismo pesquisado foi o T.denticola, um espiroqueta. A principal razão para o interesse nos espiroquetas na doença periodontal, vem da observação da sua presença aumentada nos sítios com maior profundidade de bolsa; na pequena ou nenhuma presença nos sítios sadios; e o número baixo a moderado nas áreas com gengivite mas sem perda de inserção, podendo tais microrganismos serem utilizados como possíveis indicadores diagnósticos de atividade da doença e/ou da eficácia terapêutica ${ }^{33}$. 
Segundo BIMSTEIN et al. ${ }^{9}$, espiroquetas e formas móveis devem ser parte da microbiota indígena das crianças e estudos feitos na faixa etária de 3 a 7 anos, parecem confirmá-lo, com detecção de espiroquetas em $40 \%$ e $66,7 \%$ dos indivíduos, respectivamente por LOESCHE ${ }^{52}$ e ARAÚJO; MCDONALD ${ }^{3}$. Apesar disso, o encontro pode não ser universal. SAWYER et al. ${ }^{86}$, encontraram esses microrganismos somente em crianças mal nutridas, na faixa de 1 a 5 anos, mas não naquelas com nutrição normal. Essas bactérias aumentam com a idade ${ }^{23}$, havendo relatos de 50 a $66 \%$, na faixa dos $6-12$ anos ${ }^{52,62}$.

Desde a infância até circumpuberdade, os espiroquetas se correlacionam com o índice gengival ${ }^{72,73,113}$ e com o índice de placa ${ }^{73}$.

Apesar da variada literatura sobre os espiroquetas, é difícil definir seu exato papel, pelas dificuldades técnicas no seu estudo. Os métodos de cultivo subestimam as variedades de espiroquetas da placa. De outro lado, mudanças na proporção de espécies bacterianas de morfologia semelhante não podem ser detectadas pela microscopia. Assim, um aumento na proporção de um periodontopatógeno suspeito, como o T.denticola, pode ocorrer e não ser observado, se esse aumento for contrabalançado pelo declínio de outras espécies de espiroquetas de tamanho semelhante ${ }^{82}$. Conforme ponderam HAFFAJEE; SOCRANSKY ${ }^{33}$, na análise dessa literatura, embora possam existir patógenos entre os espiroquetas, seu papel pode ter sido obscurecido pelo agrupamento inadvertido do seu número com o de espiroquetas não patogênicos.

Neste trabalho, no qual foi estudado especificamente o T.denticola, microrganismo mais comumente presente em sítios periodontalmente doentes que nos sadios; mais em sítios com periodontite severa que nos sadios ou com 
gengivite, diminuindo em sítios periodontais doentes tratados com sucesso, mas não se alterando ou aumentando em sítios que não respondem ao tratamento ${ }^{33}$, não foi possível detectá-lo em nenhuma criança, quer do grupo experimental, quer do grupo controle (TABELAS 11 e 12), conforme já observara ROSA ${ }^{82}$. Também em investigações de gengivite experimental e de gengivite de ocorrência natural, feitas em crianças entre 4 e 6 anos de idade, MOORE et al. ${ }^{68}$ e MOORE et al. ${ }^{65}$ não encontraram o T.denticola, enquanto ASHIMOTO et al. ${ }^{4}$ detectaram-no em apenas $16 \%$ de 50 crianças entre 1 e 11 anos. Diferentemente desses relatos, porém, utilizando anticorpos monoclonais, BARRON et al. ${ }^{7}$ detectaram-no em 50 e 70\%, respectivamente de crianças nas faixas de 2-4 anos e de 5-11 anos, inclusive levantando a hipótese de que talvez seja o primeiro treponema a colonizar a dentição decídua.

A não detecção da P.gingivalis e do T.denticola não significa, necessariamente, que não estejam presentes no sulco gengival da dentição decídua, mas sim, que talvez a sua quantidade esteja abaixo da sensibilidade do método utilizado. LOESCHE ${ }^{52}$, por exemplo, apesar de ter observado treponemas em $40 \%$ das crianças de 3-5 anos por ele examinadas, refere que esses microrganismos correspondiam a $<0,5 \%$ da microbiota total, o que nos leva à questão sobre o limite de detecção da técnica utilizada e o seu significado: parece ser questionável o significado clínico da detecção de patógenos que representem uma proporção diminuta da microbiota bucal ${ }^{85}$. 
As divergências entre os autores têm várias explicações. Além das influências técnicas, desde a forma de colheita até o processamento final das amostras, há que se pensar também, na probabilidade de diferentes modelos de colonização pelo mundo, resultantes dos hábitos de higiene e alimentação, costumes, genética etc.

Em relação ao método, o SIB tem vantagens significantes sobre outros métodos, como fornecer identificação rápida e específica das espécies microbianas, por técnica semi-quantitativa que processa grande número de amostras a um só tempo, com registro permanente e grande reproducibilidade. De outro lado, permite avaliar a massa da placa através da determinação do conteúdo grosseiro de carboidrato da mesma, um aspecto importante, visto que a maior dificuldade em examinar um grande número de amostras de placa consiste na incapacidade de determinar se a amostra é suficiente (ou se existe em todas), uma vez que a colheita é feita por um procedimento considerado não quantitativo. Embora a contagem microscópica possa ser a solução, é demorada e não é prática para o exame da massa ${ }^{114}$.

GREENSTEIN; LAMSTER ${ }^{32}$ ponderam, porém, que, por exemplo a maior prevalência de alguns microrganismos encontrada na população através dessas técnicas poderia ser atribuída a erros associados com a hibridização cruzada entre sondas de DNA, e resultados falso-positivos associados com as técnicas imunológicas. Mencione-se, porém, que os soros de coelho utilizados nesta pesquisa foram adsorvidos com várias bactérias bucais, demonstrando o cuidado para caracterizá-los criticamente, além de serem utilizados em diluições que afastam as reações cruzadas de menor afinidade. 
Para HAFFAJEE; SOCRANSKY ${ }^{33}$, os avanços tecnológicos muitas vezes trazem resultados surpreendentes, que podem refletir aumento da sensibilidade das técnicas ou artefatos inexplicáveis, sendo que as discrepâncias só poderão ser resolvidas por estudos adicionais.

Sobre a aquisição de microrganismos bucais, a saliva pode agir como fonte de microrganismos anaeróbios Gram negativos, para a microbiota dos bebês edêntulos ${ }^{44}$ ou dentados ${ }^{83}$, uma vez que é um indicador de colonização bucal ${ }^{83}$. Foi observado que a presença de periodontopatógenos ( $P$.gingivalis, P.intermedia/P.nigrescens e A.actinomycetemcomitans) em crianças sempre esteve associada à sua presença em pelo menos um dos pais ${ }^{78}$, apontando-os como possível fonte dos microrganismos. Membros de uma mesma família (pai, mãe e filho), mas não de famílias diferentes, compartilham cepa(s) do mesmo tipo de P.nigrescens e P.intermedia ${ }^{26,115,116}$. Outros dados parecem corroborar essa possibilidade: filhos de pais colonizados com T.denticola e P.gingivalis exibem probabilidade 9,8 vezes maior de também serem colonizados por eles ${ }^{120}$. 0 aumento do risco de colonização nas crianças, em função da presença de membros da família colonizados pela P.gingivalis, também foi observado por TUITE-MCDONNELL et al. ${ }^{110}$.

A transmissão não parece ser tão fácil, mas pode ser favorecida pela presença de doença periodontal nos pais: filhos de pais com evidência clínica de periodontite apresentam probabilidade 12 vezes maior de serem colonizados por T.denticola e P.gingivalis ${ }^{120}$. 
Discussão

Pela similaridade genética observa-se que algumas bactérias são transmitidas mais freqüentemente que outras. A P.gingivalis, por exemplo, menos freqüentemente que a P.intermedia/nigrescens. Para VAN STEENBERGEN et al. ${ }^{116}$, a observação da transmissão da P.nigrescens e P.intermedia dentro de famílias, tanto entre adultos como entre adultos e crianças, pode ser explicada pela hipótese de que essas espécies são bactérias bucais comensais, que podem colonizar as superfícies bucais com relativa facilidade. Crianças em idade prépuberdade raramente apresentam $P$.gingivalis cultivável, mesmo se seus pais abrigarem-na ${ }^{5,15}$.

É evidente que a simples presença de uma ou mais espécies patogênicas em um indivíduo seja insuficiente para produzir significante deterioração no seu estado periodontal. Essa observação pode ser explicada pela multiplicidade de outros fatores que contribuem para os resultados clínicos, incluindo fatores do hospedeiro e ambientais, bem como interações bacterianas locais que podem modular a virulência de espécies de outro modo consideradas patogênicas ${ }^{49}$.

Isto posto, no momento, o fato de ter sido confirmada a transferência de bactérias entre humanos não constitui evidência suficiente para se propor grandes programas comunitários para tentar limitar a transmissão de bactérias que podem ou não ser patogênicas num indivíduo particular. Todavia, dentro de famílias onde tenha sido identificado um indivíduo altamente suscetível à periodontite, pode ser prudente aumentar o monitoramento dos demais membros. No futuro, se existirem testes para diferenciar cepas virulentas de cepas não virulentas de 
bactérias, distinguir microrganismos exógenos de endógenos, separar os indivíduos suscetíveis dos resistentes e esclarecer o número necessário do patógeno para induzir a doença, a capacidade do clínico para interferir na cadeia de infecção e reduzir o início da doença será enormemente melhorada ${ }^{32}$.

A falta de diferença demonstrável entre as microbiotas das crianças não fissuradas e portadoras de fissuras sugere que a gengivite mais intensa nas últimas parece estar relacionada com higiene relativamente pobre, antes que com uma composição bacteriana diferente, merecendo, porém, maior investigação com outros periodontopatógenos conhecidos. Os únicos autores que avaliaram tanto clínica como microbiologicamente portadores de fissuras operados adultos, MOMBELLI; BRÄGGER; LANG ${ }^{64}$, dão suporte a essa afirmação.

Esses autores não só demonstraram que esses pacientes não submetidos a manutenção regular apresentam índices de placa e sangramento à sondagem significantemente maiores, como também não detectaram o A.actinomycetemcomitans e a $P$. gingivalis nos pacientes com ou sem supervisão, afirmando que, mais importante que os aspectos morfológicos locais para a perda periodontal (a área próxima e a distante à fenda têm a mesma suscetibilidade), são os cuidados de higiene, cuja ausência favorece maiores proporções de microrganismos e presença de espiroquetas, por exemplo ${ }^{64}$.

Provavelmente a observação vista nos quatro sítios, no presente trabalho, pode se estender para outras áreas, uma vez que a composição da microbiota de sítios com diferentes escores de índice gengival não difere significantemente. 
Considerando as particularidades inerentes ao portador de fissura, que dificultam os procedimentos de higiene bucal na região afetada, os pais, responsáveis pela realização da limpeza bucal de seus filhos na infância, devem ser precocemente orientados e treinados para tal procedimento.

Todavia, ainda existem muitas limitações para que os pais sejam educados em relação a saúde bucal de seus filhos e para que haja uma prevenção efetiva das doenças bucais nas crianças portadoras de fissura.

Uma constatação a que se chega, através da vivência no atendimento de crianças portadoras de fissura de lábio e/ou palato no HRAC-USP, é a dificuldade em se provocar nos pais dos bebês, a motivação necessária para os cuidados nos procedimentos de limpeza bucal e para a alimentação adequada de seus filhos, apesar das orientações fornecidas, por estarem suas preocupações, nesta fase da vida, mais voltadas para os procedimentos cirúrgicos reparadores. Segundo DAHLLÖFF ${ }^{20}$, um outro fator que poderia interferir na aquisição precoce de hábitos inadequados em portadores de fissura seria a reação psicológica gerada pela malformação estética e funcional, que influenciaria os pais a terem uma atitude mais permissiva em relação à freqüência e aos tipos de alimentos ingeridos nos intervalos das refeições.

De outro lado, apesar do grande número de profissionais bem treinados que exercem a Odontologia hoje em dia, ainda há um mito em relação ao tratamento de pacientes portadores de fissuras lábio-palatais, sendo que muitos recusam-se a atendê-los, por insegurança, principalmente em relação aos dentes da região da fissura. 
Para obter-se a prevenção de doença periodontal nessas crianças é imprescindível, além do cuidado domiciliar, o acompanhamento regular por parte do Odontopediatra a fim de que possa avaliar a presença de fatores etiológicos, realizar limpeza dentária profissional regular e identificar a presença de outros fatores de risco, alertando aos pais, nesses casos, sobre a importância mais acentuada de controle da placa dentária.

O significado disso, diante da evolução do tratamento é inquestionável. Para os pacientes portadores de fissuras alveolares, os efeitos deletérios dos tratamentos ortodônticos prolongados, do uso de próteses removíveis e fixas bem como do longo período de reabilitação têm atualmente sido minimizados através da realização de uma cirurgia de enxerto ósseo na região da fissura, na fase da dentadura mista, que proporciona a restauração do processo alveolar e permite que os dentes adjacentes migrem ou sejam ortodonticamente movidos para a área do osso enxertado. Desta forma, reduz-se a necessidade da utilização de próteses para a reposição de dentes ausentes ou contenções ortodônticas para manter a estabilidade dos segmentos maxilares, permitindo o término do tratamento em idades mais precoces. Além disso, as fístulas buco-nasais são fechadas, os nichos mucosos são eliminados (facilitando a higiene bucal) e a saúde periodontal dos dentes adjacentes à fissura é melhorada a longo-prazo ${ }^{88}$.

O enxerto ósseo alveolar tem produzido resultados tão bons que tem sido afirmado que a condição periodontal pode ser normalizada após o enxerto e que raramente, observa-se gengivite na região da fissura; no entanto, segundo; JOHANSON et al. ${ }^{37}$ e WONG; KING ${ }^{125}$, a saúde gengival pré-operatória tem sido considerada o principal fator na determinação do sucesso da cirurgia. 
7 Conclusões 


\section{7 - CONCLUSÕES}

Os resultados obtidos a partir da avaliação clínica e análise das placas subgengivais de crianças, portadoras ou não de fissuras, com idades entre 5 e 6 anos, permitiram-nos concluir, respeitando os limites da técnica do "Slot Immunoblot", que:

- as crianças portadoras de fissura apresentaram índices gengivais significantemente maiores que as crianças sem fissura, mesmo sem apresentar índices de placa significantemente diferentes;

- não se observou diferença estatisticamente significante na severidade do IP e do IG entre os dois grupos;

- nas crianças portadoras de fissura a comparação das variáveis clínicas entre os sítios normais (4 sítios) e áreas da fissura (2 sítios) revelou índice de placa significantemente maior na região da fissura, sem diferença, porém, no índice gengival;

- a prevalência de detecção da $P$. nigrescens foi de $16,67 \%$, no grupo experimental e de $11,11 \%$, no grupo controle, sem diferença estatisticamente significante entre os grupos, enquanto a $P$. gingivalis e o $T$. denticola não foram detectados;

- a presença da fissura não contribuiu para maior freqüência de aquisição dos periodontopatógenos pesquisados; 
- a maior prevalência de inflamação gengival nas crianças portadoras de fissuras denotou a importância de um acompanhamento precoce e regular de sua saúde periodontal, para favorecer o prognóstico do tratamento reabilitador. 
Anexos 
ANEXO A - Autorização dos pais para a participação dos filhos na pesquisa (grupo experimental)

\section{UNIVERSIDADE DE SÃO PAULO \\ HOSPITAL DE REABILITAÇÃO DE ANOMALIAS CRANIOFACIAIS}

\section{AUTORIZAÇÃO}

Após ter tomado ciência da pesquisa a ser realizada no Setor de Odontopediatria do Hospital de Reabilitação de Anomalias Craniofaciais - USP, para verificar as condições bucais de crianças portadoras de fissura de lábio e palato já operadas com idades entre 5 e 6 anos, que consistirá de exame da placa sobre os dentes, do estado da gengiva e a colheita de amostras de placa da gengiva de seis dentes, sabendo que o seu objetivo é verificar se as crianças exibem bactérias que estão associadas à inflamação gengival, para o estabelecimento de programas preventivos, AUTORIZO a inclusão do(a) meu(minha) filho(a), tendo em vista a disposição de minha família em colaborar e por preencher o requisito básico da pesquisa, ou seja, que a criança não tenha tomado antibióticos nos últimos 3 meses.

Bauru,

(mãe de: 


\begin{abstract}
ANEXO B - Autorização dos pais para a participação dos filhos na pesquisa (grupo controle)
\end{abstract}

\title{
UNIVERSIDADE DE SÃO PAULO \\ FACULDADE DE ODONTOLOGIA DE BAURU
}

\section{AUTORIZAÇÃO}

Após ter tomado ciência da pesquisa a ser realizada por Professores da Faculdade de Odontologia de Bauru - USP, para verificar as condições bucais de crianças entre 5 e 6 anos, que consistirá do exame da placa sobre os dentes, do estado da gengiva e a colheita de amostras de placa de quatro dentes, sabendo que seu objetivo é verificar se as crianças exibem bactérias que estão associadas com a inflamação gengival, para estabelecer programas preventivos, AUTORIZO a inclusão do(a) meu (minha) filho(a), tendo em vista a disposição de minha família em colaborar e por preencher o requisito básico da pesquisa, ou seja, que a criança não tenha tomado antibiótico nos três últimos meses.

Bauru,

(mãe de: 


\section{ANEXO C - Relatório de Aprovação pelo Comitê de Ética}

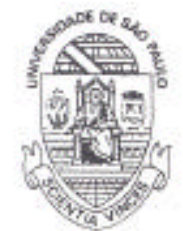

Of. $\mathrm{N}^{\circ}$

\section{UNIVERSIDADE DE SÃO PAULO}

HOSPITAL DE REABILITAÇÃO DE ANOMALIAS CRANIOFACIAIS

Rua Silvio Marchione, 3-20 - Caixa Postal, 620-Telefone (014) 235-8000-CEP 17043-900

BAURU - S.P. - Brasil

Bauru, 10 de setembro de 1999.

Prezada Senhora

Comunicamos que em reunião realizada no dia 08 de setembro de 1999 , pelo Comitẽ de Ética em Pesquisa, o projeto de pesquisa abaixo relacionado, foi aprovado.

TITULO: Prevalência de microrganismos na placa sub gengival de dentição decidua de crianças portadoras de fissura completa de lábio e palato operadas

FINALIDADE: Doutorado

Atenciosamente

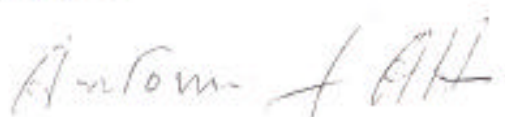

PROF, DR. ANTONIO GABRIEL ATTA

Presidente do Comitê de Ética em Pesquisa

Ilma. Sra.

Beatriz Costa

Odontopediatria do HRAC-USP 
ANEXO D - Modelo de ficha para anotação do índice de placa e índice gengival

\section{UNIVERSIDADE DE SÃO PAULO}

\section{HOSPITAL DE REABILITAÇÃO DE ANOMALIAS CRANIOFACIAIS} SETOR DE ODONTOPEDIATRIA

\begin{tabular}{|c|}
\hline Nome: \\
\hline
\end{tabular}

Tipo de fissura: ( ) TIUD ( ) TIUE Data de nascimento:

Data do exame:

\begin{tabular}{|c|c|c|c|c|c|c|c|c|c|c|c|c|c|c|c|c|c|c|c|c|c|c|c|c|c|c|c|c|c|}
\hline & \multicolumn{4}{|c|}{55} & \multicolumn{4}{|c|}{$F$} & \multicolumn{4}{|c|}{$f$} & \multicolumn{4}{|c|}{65} & \multicolumn{4}{|c|}{75} & \multicolumn{4}{|c|}{85} & \multicolumn{5}{|c|}{ TOTAL } \\
\hline & $\mathbf{M}$ & $\mathbf{V}$ & D & $\mathbf{L}$ & $\mathbf{M}$ & $\mathbf{V}$ & D & $\mathbf{L}$ & $\mathbf{M}$ & $\mathbf{V}$ & D & L & $\mathbf{M}$ & $\mathbf{V}$ & D & $\mathbf{L}$ & $\mathbf{M}$ & $\mathbf{V}$ & D & $\mathbf{L}$ & $\mathbf{M}$ & $\mathbf{V}$ & D & $\mathbf{L}$ & $\mathbf{M}$ & $\mathbf{V}$ & D & $\mathbf{L}$ & FACES \\
\hline IG & & & & & & & & & & & & & & & & & & & & & & & & & & & & & \\
\hline IP & & & & & & & & & & & & & & & & & & & & & & & & & & & & & \\
\hline
\end{tabular}

\begin{tabular}{|c|c|c|}
\hline & IG & IP \\
\hline Soma dos scores & & \\
\hline $\mathbf{N}^{\circ}$ de faces examinadas & & \\
\hline VALOR FINAL & & \\
\hline
\end{tabular}


Anexos

ANEXO E - Escores detectados para o carboidrato, $P$. gingivalis, $P$. nigrescens e T. denticola nas amostras de placa subgengivais de cada sítio amostrado (grupo experimental).

\begin{tabular}{|c|c|c|c|c|c|}
\hline Amostra \# & Sítios & Carboidrato & P.gingivalis & P.nigrescens & T.denticola \\
\hline \multirow[t]{6}{*}{1} & 1 & 3 & 0 & 0 & 0 \\
\hline & 2 & 1 & 0 & 0 & 0 \\
\hline & 3 & 2 & 0 & 0 & 0 \\
\hline & 4 & 3 & 0 & 0 & 0 \\
\hline & 5 & 2 & 0 & 0 & 0 \\
\hline & 6 & 3 & 0 & 0 & 0 \\
\hline \multirow[t]{6}{*}{2} & 1 & 3 & 0 & 0 & 0 \\
\hline & 2 & 2 & 0 & 0 & 0 \\
\hline & 3 & 1 & 0 & 0 & 0 \\
\hline & 4 & 3 & 0 & 1 & 0 \\
\hline & 5 & 3 & 0 & 0 & 0 \\
\hline & 6 & 3 & 0 & 0 & 0 \\
\hline \multirow[t]{6}{*}{3} & 1 & 2 & 0 & 0 & 0 \\
\hline & 2 & 3 & 0 & 0 & 0 \\
\hline & 3 & 2 & 0 & 0 & 0 \\
\hline & 4 & 2 & 0 & 0 & 0 \\
\hline & 5 & 3 & 0 & 1 & 0 \\
\hline & 6 & 3 & 0 & 0 & 0 \\
\hline \multirow[t]{6}{*}{4} & 1 & 3 & 0 & 0 & 0 \\
\hline & 2 & 3 & 0 & 0 & 0 \\
\hline & 3 & 3 & 0 & 0 & 0 \\
\hline & 4 & 3 & 0 & 0 & 0 \\
\hline & 5 & 3 & 0 & 0 & 0 \\
\hline & 6 & 2 & 0 & 0 & 0 \\
\hline \multirow[t]{6}{*}{5} & 1 & 3 & 0 & 0 & 0 \\
\hline & 2 & 3 & 0 & 0 & 0 \\
\hline & 3 & 2 & 0 & 0 & 0 \\
\hline & 4 & 3 & 0 & 0 & 0 \\
\hline & 5 & 3 & 0 & 0 & 0 \\
\hline & 6 & 1 & 0 & 0 & 0 \\
\hline \multirow[t]{6}{*}{6} & 1 & 1 & 0 & 0 & 0 \\
\hline & 2 & 2 & 0 & 0 & 0 \\
\hline & 3 & 2 & 0 & 0 & 0 \\
\hline & 4 & 3 & 0 & 0 & 0 \\
\hline & 5 & 3 & 0 & 0 & 0 \\
\hline & 6 & 3 & 0 & 0 & 0 \\
\hline \multirow[t]{6}{*}{7} & 1 & 3 & 0 & 0 & 0 \\
\hline & 2 & 3 & 0 & 0 & 0 \\
\hline & 3 & 3 & 0 & 0 & 0 \\
\hline & 4 & 3 & 0 & 0 & 0 \\
\hline & 5 & 2 & 0 & 0 & 0 \\
\hline & 6 & 3 & 0 & 0 & 0 \\
\hline \multirow[t]{6}{*}{8} & 1 & 3 & 0 & 1 & 0 \\
\hline & 2 & 3 & 0 & 0 & 0 \\
\hline & 3 & 3 & 0 & 0 & 0 \\
\hline & 4 & 3 & 0 & 0 & 0 \\
\hline & 5 & 3 & 0 & 0 & 0 \\
\hline & 6 & 3 & 0 & 0 & 0 \\
\hline
\end{tabular}




\begin{tabular}{|c|c|c|c|c|c|}
\hline Amostra \# & Sítios & Carboidrato & P.gingivalis & P.nigrescens & T.denticola \\
\hline \multirow[t]{6}{*}{9} & 1 & 1 & 0 & 0 & 0 \\
\hline & 2 & 1 & 0 & 0 & 0 \\
\hline & 3 & 3 & 0 & 0 & 0 \\
\hline & 4 & 3 & 0 & 0 & 0 \\
\hline & 5 & 3 & 0 & 0 & 0 \\
\hline & 6 & 2 & 0 & 0 & 0 \\
\hline \multirow[t]{6}{*}{10} & 1 & 3 & 0 & 0 & 0 \\
\hline & 2 & 1 & 0 & 0 & 0 \\
\hline & 3 & 2 & 0 & 0 & 0 \\
\hline & 4 & 2 & 0 & 0 & 0 \\
\hline & 5 & 2 & 0 & 0 & 0 \\
\hline & 6 & 2 & 0 & 0 & 0 \\
\hline \multirow[t]{6}{*}{11} & 1 & 3 & 0 & 0 & 0 \\
\hline & 2 & 1 & 0 & 0 & 0 \\
\hline & 3 & 3 & 0 & 0 & 0 \\
\hline & 4 & 1 & 0 & 0 & 0 \\
\hline & 5 & 1 & 0 & 0 & 0 \\
\hline & 6 & 2 & 0 & 0 & 0 \\
\hline \multirow[t]{6}{*}{12} & 1 & 2 & 0 & 0 & 0 \\
\hline & 2 & 3 & 0 & 0 & 0 \\
\hline & 3 & 2 & 0 & 1 & 0 \\
\hline & 4 & 2 & 0 & 0 & 0 \\
\hline & 5 & 3 & 0 & 1 & 0 \\
\hline & 6 & 3 & 0 & 0 & 0 \\
\hline \multirow[t]{6}{*}{13} & 1 & 1 & 0 & 0 & 0 \\
\hline & 2 & 0 & 0 & 0 & 0 \\
\hline & 3 & 3 & 0 & 0 & 0 \\
\hline & 4 & 0 & 0 & 0 & 0 \\
\hline & 5 & 2 & 0 & 0 & 0 \\
\hline & 6 & 2 & 0 & 0 & 0 \\
\hline \multirow[t]{6}{*}{14} & 1 & 2 & 0 & 0 & 0 \\
\hline & 2 & 2 & 0 & 0 & 0 \\
\hline & 3 & 3 & 0 & 0 & 0 \\
\hline & 4 & 2 & 0 & 1 & 0 \\
\hline & 5 & 3 & 0 & 0 & 0 \\
\hline & 6 & 3 & 0 & 1 & 0 \\
\hline \multirow[t]{6}{*}{15} & 1 & 3 & 0 & 0 & 0 \\
\hline & 2 & 3 & 0 & 0 & 0 \\
\hline & 3 & 2 & 0 & 0 & 0 \\
\hline & 4 & 3 & 0 & 0 & 0 \\
\hline & 5 & 3 & 0 & 0 & 0 \\
\hline & 6 & 3 & 0 & 0 & 0 \\
\hline \multirow[t]{6}{*}{16} & 1 & 1 & 0 & 0 & 0 \\
\hline & 2 & 2 & 0 & 0 & 0 \\
\hline & 3 & 2 & 0 & 0 & 0 \\
\hline & 4 & 2 & 0 & 0 & 0 \\
\hline & 5 & 1 & 0 & 0 & 0 \\
\hline & 6 & 2 & 0 & 0 & 0 \\
\hline
\end{tabular}




\begin{tabular}{|c|c|c|c|c|c|}
\hline Amostra \# & Sítios & Carboidrato & P.gingivalis & P.nigrescens & T.denticola \\
\hline \multirow[t]{6}{*}{17} & 1 & 3 & 0 & 0 & 0 \\
\hline & 2 & 3 & 0 & 0 & 0 \\
\hline & 3 & 2 & 0 & 0 & 0 \\
\hline & 4 & 3 & 0 & 0 & 0 \\
\hline & 5 & 3 & 0 & 0 & 0 \\
\hline & 6 & 3 & 0 & 0 & 0 \\
\hline \multirow[t]{6}{*}{18} & 1 & 1 & 0 & 0 & 0 \\
\hline & 2 & 0 & 0 & 0 & 0 \\
\hline & 3 & 0 & 0 & 0 & 0 \\
\hline & 4 & 1 & 0 & 0 & 0 \\
\hline & 5 & 2 & 0 & 0 & 0 \\
\hline & 6 & 2 & 0 & 0 & 0 \\
\hline \multirow[t]{6}{*}{19} & 1 & 2 & 0 & 0 & 0 \\
\hline & 2 & 1 & 0 & 0 & 0 \\
\hline & 3 & 2 & 0 & 0 & 0 \\
\hline & 4 & 2 & 0 & 0 & 0 \\
\hline & 5 & 2 & 0 & 0 & 0 \\
\hline & 6 & 2 & 0 & 0 & 0 \\
\hline \multirow[t]{6}{*}{20} & 1 & 3 & 0 & 0 & 0 \\
\hline & 2 & 2 & 0 & 0 & 0 \\
\hline & 3 & 3 & 0 & 0 & 0 \\
\hline & 4 & 3 & 0 & 0 & 0 \\
\hline & 5 & 3 & 0 & 0 & 0 \\
\hline & 6 & 3 & 0 & 0 & 0 \\
\hline \multirow[t]{6}{*}{21} & 1 & 3 & 0 & 0 & 0 \\
\hline & 2 & 2 & 0 & 0 & 0 \\
\hline & 3 & 1 & 0 & 0 & 0 \\
\hline & 4 & 2 & 0 & 0 & 0 \\
\hline & 5 & 3 & 0 & 0 & 0 \\
\hline & 6 & 3 & 0 & 0 & 0 \\
\hline \multirow[t]{6}{*}{22} & 1 & 2 & 0 & 0 & 0 \\
\hline & 2 & 0 & 0 & 0 & 0 \\
\hline & 3 & 3 & 0 & 0 & 0 \\
\hline & 4 & 3 & 0 & 0 & 0 \\
\hline & 5 & 2 & 0 & 0 & 0 \\
\hline & 6 & 3 & 0 & 0 & 0 \\
\hline \multirow[t]{6}{*}{23} & 1 & 3 & 0 & 0 & 0 \\
\hline & 2 & 2 & 0 & 0 & 0 \\
\hline & 3 & 2 & 0 & 0 & 0 \\
\hline & 4 & 3 & 0 & 0 & 0 \\
\hline & 5 & 2 & 0 & 0 & 0 \\
\hline & 6 & 3 & 0 & 0 & 0 \\
\hline \multirow[t]{6}{*}{24} & 1 & 3 & 0 & 0 & 0 \\
\hline & 2 & 3 & 0 & 0 & 0 \\
\hline & 3 & 3 & 0 & 0 & 0 \\
\hline & 4 & 3 & 0 & 0 & 0 \\
\hline & 5 & 3 & 0 & 0 & 0 \\
\hline & 6 & 3 & 0 & 0 & 0 \\
\hline
\end{tabular}




\begin{tabular}{|c|c|c|c|c|c|}
\hline Amostra \# & Sítios & Carboidrato & P.gingivalis & P.nigrescens & T.denticola \\
\hline \multirow[t]{6}{*}{25} & 1 & 2 & 0 & 0 & 0 \\
\hline & 2 & 0 & 0 & 0 & 0 \\
\hline & 3 & 1 & 0 & 0 & 0 \\
\hline & 4 & 2 & 0 & 0 & 0 \\
\hline & 5 & 2 & 0 & 0 & 0 \\
\hline & 6 & 2 & 0 & 0 & 0 \\
\hline \multirow[t]{6}{*}{26} & 1 & 1 & 0 & 0 & 0 \\
\hline & 2 & 2 & 0 & 0 & 0 \\
\hline & 3 & 1 & 0 & 0 & 0 \\
\hline & 4 & 2 & 0 & 0 & 0 \\
\hline & 5 & 1 & 0 & 0 & 0 \\
\hline & 6 & 2 & 0 & 0 & 0 \\
\hline \multirow[t]{6}{*}{27} & 1 & 2 & 0 & 0 & 0 \\
\hline & 2 & 1 & 0 & 0 & 0 \\
\hline & 3 & 1 & 0 & 0 & 0 \\
\hline & 4 & 0 & 0 & 0 & 0 \\
\hline & 5 & 1 & 0 & 0 & 0 \\
\hline & 6 & 1 & 0 & 0 & 0 \\
\hline \multirow[t]{6}{*}{28} & 1 & 2 & 0 & 0 & 0 \\
\hline & 2 & 3 & 0 & 0 & 0 \\
\hline & 3 & 1 & 0 & 0 & 0 \\
\hline & 4 & 3 & 0 & 0 & 0 \\
\hline & 5 & 2 & 0 & 0 & 0 \\
\hline & 6 & 2 & 0 & 0 & 0 \\
\hline \multirow[t]{6}{*}{29} & 1 & 2 & 0 & 0 & 0 \\
\hline & 2 & 1 & 0 & 0 & 0 \\
\hline & 3 & 1 & 0 & 0 & 0 \\
\hline & 4 & 2 & 0 & 0 & 0 \\
\hline & 5 & 3 & 0 & 0 & 0 \\
\hline & 6 & 3 & 0 & 0 & 0 \\
\hline \multirow[t]{6}{*}{30} & 1 & 0 & 0 & 0 & 0 \\
\hline & 2 & 1 & 0 & 0 & 0 \\
\hline & 3 & 2 & 0 & 0 & 0 \\
\hline & 4 & 1 & 0 & 0 & 0 \\
\hline & 5 & 2 & 0 & 0 & 0 \\
\hline & 6 & 3 & 0 & 0 & 0 \\
\hline
\end{tabular}


Anexos

ANEXO F - Escores detectados para o carboidrato, $P$. gingivalis, $P$. nigrescens e $T$. denticola nas amostras de placa subgengivais de cada sítio amostrado (grupo controle).

\begin{tabular}{|c|c|c|c|c|c|}
\hline Amostra \# & Sítios & Carboidrato & P.gingivalis & P.nigrescens & T.denticola \\
\hline \multirow[t]{4}{*}{1} & 1 & 3 & 0 & 0 & 0 \\
\hline & 2 & 3 & 0 & 0 & 0 \\
\hline & 3 & 3 & 0 & 0 & 0 \\
\hline & 4 & 3 & 0 & 0 & 0 \\
\hline \multirow[t]{4}{*}{2} & 1 & 3 & 0 & 0 & 0 \\
\hline & 2 & 2 & 0 & 0 & 0 \\
\hline & 3 & 2 & 0 & 0 & 0 \\
\hline & 4 & 3 & 0 & 0 & 0 \\
\hline \multirow[t]{4}{*}{3} & 1 & 2 & 0 & 0 & 0 \\
\hline & 2 & 2 & 0 & 0 & 0 \\
\hline & 3 & 3 & 0 & 0 & 0 \\
\hline & 4 & 3 & 0 & 0 & 0 \\
\hline \multirow[t]{4}{*}{4} & 1 & 2 & 0 & 0 & 0 \\
\hline & 2 & 3 & 0 & 0 & 0 \\
\hline & 3 & 2 & 0 & 0 & 0 \\
\hline & 4 & 3 & 0 & 0 & 0 \\
\hline \multirow[t]{4}{*}{5} & 1 & 3 & 0 & 0 & 0 \\
\hline & 2 & 3 & 0 & 0 & 0 \\
\hline & 3 & 3 & 0 & 0 & 0 \\
\hline & 4 & 2 & 0 & 0 & 0 \\
\hline \multirow[t]{4}{*}{6} & 1 & 2 & 0 & 0 & 0 \\
\hline & 2 & 1 & 0 & 0 & 0 \\
\hline & 3 & 3 & 0 & 0 & 0 \\
\hline & 4 & 3 & 0 & 0 & 0 \\
\hline \multirow[t]{4}{*}{7} & 1 & 3 & 0 & 0 & 0 \\
\hline & 2 & 3 & 0 & 0 & 0 \\
\hline & 3 & 3 & 0 & 0 & 0 \\
\hline & 4 & 3 & 0 & 0 & 0 \\
\hline \multirow[t]{4}{*}{8} & 1 & 2 & 0 & 0 & 0 \\
\hline & 2 & 3 & 0 & 2 & 0 \\
\hline & 3 & 3 & 0 & 1 & 0 \\
\hline & 4 & 3 & 0 & 0 & 0 \\
\hline \multirow[t]{4}{*}{9} & 1 & 2 & 0 & 0 & 0 \\
\hline & 2 & 3 & 0 & 0 & 0 \\
\hline & 3 & 0 & 0 & 0 & 0 \\
\hline & 4 & 1 & 0 & 0 & 0 \\
\hline
\end{tabular}




\begin{tabular}{|c|c|c|c|c|c|}
\hline Amostra \# & Sítios & Carboidrato & P.gingivalis & P.nigrescens & T.denticola \\
\hline \multirow[t]{4}{*}{10} & 1 & 3 & 0 & 0 & 0 \\
\hline & 2 & 3 & 0 & 0 & 0 \\
\hline & 3 & 3 & 0 & 0 & 0 \\
\hline & 4 & 3 & 0 & 0 & 0 \\
\hline \multirow[t]{4}{*}{11} & 1 & 3 & 0 & 0 & 0 \\
\hline & 2 & 3 & 0 & 0 & 0 \\
\hline & 3 & 3 & 0 & 1 & 0 \\
\hline & 4 & 3 & 0 & 0 & 0 \\
\hline \multirow[t]{4}{*}{12} & 1 & 3 & 0 & 0 & 0 \\
\hline & 2 & 3 & 0 & 0 & 0 \\
\hline & 3 & 3 & 0 & 0 & 0 \\
\hline & 4 & 3 & 0 & 0 & 0 \\
\hline \multirow[t]{4}{*}{13} & 1 & 2 & 0 & 0 & 0 \\
\hline & 2 & 2 & 0 & 0 & 0 \\
\hline & 3 & 3 & 0 & 0 & 0 \\
\hline & 4 & 3 & 0 & 0 & 0 \\
\hline \multirow[t]{4}{*}{14} & 1 & 2 & 0 & 0 & 0 \\
\hline & 2 & 3 & 0 & 1 & 0 \\
\hline & 3 & 2 & 0 & 0 & 0 \\
\hline & 4 & 3 & 0 & 0 & 0 \\
\hline \multirow[t]{4}{*}{15} & 1 & 3 & 0 & 0 & 0 \\
\hline & 2 & 3 & 0 & 0 & 0 \\
\hline & 3 & 2 & 0 & 0 & 0 \\
\hline & 4 & 3 & 0 & 0 & 0 \\
\hline \multirow[t]{4}{*}{16} & 1 & 3 & 0 & 0 & 0 \\
\hline & 2 & 2 & 0 & 0 & 0 \\
\hline & 3 & 1 & 0 & 0 & 0 \\
\hline & 4 & 2 & 0 & 0 & 0 \\
\hline \multirow[t]{4}{*}{17} & 1 & 2 & 0 & 0 & 0 \\
\hline & 2 & 3 & 0 & 0 & 0 \\
\hline & 3 & 2 & 0 & 0 & 0 \\
\hline & 4 & 3 & 0 & 0 & 0 \\
\hline \multirow[t]{4}{*}{18} & 1 & 2 & 0 & 0 & 0 \\
\hline & 2 & 3 & 0 & 0 & 0 \\
\hline & 3 & 3 & 0 & 0 & 0 \\
\hline & 4 & 3 & 0 & 0 & 0 \\
\hline
\end{tabular}




\begin{tabular}{|c|c|c|c|c|c|}
\hline Amostra \# & Sítios & Carboidrato & P.gingivalis & P.nigrescens & T.denticola \\
\hline \multirow[t]{4}{*}{19} & 1 & 1 & 0 & 0 & 0 \\
\hline & 2 & 2 & 0 & 0 & 0 \\
\hline & 3 & 2 & 0 & 0 & 0 \\
\hline & 4 & 3 & 0 & 0 & 0 \\
\hline \multirow[t]{4}{*}{20} & 1 & 2 & 0 & 0 & 0 \\
\hline & 2 & 2 & 0 & 0 & 0 \\
\hline & 3 & 3 & 0 & 0 & 0 \\
\hline & 4 & 3 & 0 & 0 & 0 \\
\hline \multirow{4}{*}{21} & 1 & 2 & 0 & 0 & 0 \\
\hline & 2 & 2 & 0 & 0 & 0 \\
\hline & 3 & 1 & 0 & 0 & 0 \\
\hline & 4 & 3 & 0 & 0 & 0 \\
\hline \multirow[t]{4}{*}{22} & 1 & 3 & 0 & 0 & 0 \\
\hline & 2 & 3 & 0 & 0 & 0 \\
\hline & 3 & 3 & 0 & 0 & 0 \\
\hline & 4 & 3 & 0 & 0 & 0 \\
\hline \multirow[t]{4}{*}{23} & 1 & 3 & 0 & 0 & 0 \\
\hline & 2 & 3 & 0 & 0 & 0 \\
\hline & 3 & 2 & 0 & 0 & 0 \\
\hline & 4 & 3 & 0 & 0 & 0 \\
\hline \multirow[t]{4}{*}{24} & 1 & 2 & 0 & 0 & 0 \\
\hline & 2 & 2 & 0 & 0 & 0 \\
\hline & 3 & 3 & 0 & 0 & 0 \\
\hline & 4 & 3 & 0 & 0 & 0 \\
\hline \multirow[t]{4}{*}{25} & 1 & 3 & 0 & 0 & 0 \\
\hline & 2 & 2 & 0 & 0 & 0 \\
\hline & 3 & 1 & 0 & 0 & 0 \\
\hline & 4 & 1 & 0 & 0 & 0 \\
\hline \multirow[t]{4}{*}{26} & 1 & 3 & 0 & 0 & 0 \\
\hline & 2 & 3 & 0 & 0 & 0 \\
\hline & 3 & 2 & 0 & 0 & 0 \\
\hline & 4 & 3 & 0 & 0 & 0 \\
\hline \multirow[t]{4}{*}{27} & 1 & 2 & 0 & 0 & 0 \\
\hline & 2 & 3 & 0 & 0 & 0 \\
\hline & 3 & 3 & 0 & 0 & 0 \\
\hline & 4 & 3 & 0 & 0 & 0 \\
\hline
\end{tabular}




\section{Referências Bibliográficas}




\section{REFERÊNCIAS BIBLIOGRÁFICAS*}

01 - ABRAHAM, J. et al. Assessing periodontal pathogens in children with varying levels of oral hygiene. J.dent.Child., v.57, n.3, p.189-93, May/June 1990.

02 - ABYHOLM, F.E. Cleft lip and palate in Norway. I-Registration; incidence, and early mortality of infants with cleft lip and palate. Scand. J. Plast. Reconstr. Surg., v.12, n.1, p. 29-34, 1978.

03 - ARAUJO, W.C.; MACDONALD, J.B. The gingival crevice microbiota in five preschool children. Arch. oral Biol., v.9, n.2, p.227-8, Mar./Apr. 1964.

04 - ASHIMOTO, A. et al. Polymerase chain reaction detection of 8 putative periodontal pathogens in subgingival plaque of gingivitis and advanced periodontitis lesions. Oral Microbiol. Immunol., v.11, n.4, p.266-73, Aug. 1996.

05 - ASIKAINEN, S.; CHEN, C.; SLOTS, J. Likelihood of transmitting Actinobacillus actinomycetemcomitans and Porphyromonas gingivalis in families with periodontitis. Oral Microbiol. Immunol., v.11, n.6, p.387-94, Dec. 1996.

* Normas recomendadas para uso no âmbito da Universidade de São Paulo, com base no documento: "Referências Bibliográficas: exemplos", emanado do Conselho Supervisor do Sistema Integrado de Bibliotecas da USP, em reunião de 20 de setembro de 1990. 
06 - BAILIT, H.L.; BALDWIN, D.C.; HUNT JR., E.E. The increasing prevalence of gingival Bacteroides melaninogenicus with age in children. Arch. oral Biol., v.9, n.4, p.435-8, July/Aug. 1964.

07 - BARRON, S.L. et al. Use of monoclonal antibodies to enumerate spirochetes and identify Treponema denticola in dental plaque of children, adolescents and young adults. Oral Microbiol. Immunol., v.6, n.2, p.97-101, Apr. 1991.

08 - BERGLAND, O.; SHIDU, S. Oclusal changes from the deciduous to the early mixed dentition in unilateral complete clefts. Cleft Palate J., v. 11, p. 31726, July 1974.

09 - BIMSTEIN, E. et al. The composition of subgengival microflora in two groups of children with and without primary dentition alveolar bone loss. Pediat. Dent., v.18, n.1, p.42-7, Jan./Feb. 1996.

10 - BIMSTEIN, E.; MATSSON, L. Growth and development considerations in the diagnosis of gingivitis and periodontitis in children. Pediat. Dent., v.21, n.3, p.186-91, May/June 1999. 
11 - BOKHOUT, B. et al. Incidence of dental caries in the primary dentition in children with a cleft lip and/or palate. Caries Res., v.31, n.1, p. 8-12, Jan./Feb. 1997.

12 - BRÄGGER, U. et al. Periodontal conditions in adolescents with cleft lip, alveolus and palate following treatment in a co-ordinated team approach. J. clin. Periodont., v.12, n.6, p.494-502, July 1985.

13 - BRÄGGER, U. et al. The significance of alveolar bone in periodontal disease: a long term observation in patients with cleft lip, alveolus and palate. $\mathbf{J}$. clin. Periodont., v.17, n.6, p.379-84, July 1990.

14 - BRÄGGER, U. et al. Periodontal conditions in adult patients with cleft lip, alveolus and palate. Cleft Palate-Craniof. J., v.29, n.2, p.179-85, Mar. 1992.

15 - BRETZ, W. et al. Concordância familiar de indicadores microbianos em amostras de placa subgengival. In : REUNIÃO CIENTÍFICA DA SOCIEDADE BRASILEIRA DE PESQUISA ODONTOLÓGICA, 10., Águas de São Pedro, 1993. Anais. Bauru, SBPqO, 1993.

16 - CONRADS,G. et al. PCR reaction and dot-blot hybridization to monitor the distribution of oral pathogens within plaque samples of periodontally healthy individuals. J.Periodont., v.67, n.10, p.994-1003, Oct. 1996. 
17 - CUNHA, A.C.P.; CHAMBRONE, L.A. Prevalência de gengivite em crianças. Rev. Period., v.7, n.1, p.1-5, jan./abr. 1998.

18 - CUNHA, A.C.P.; CHAMBRONE, L.A. Prevalência de gengivite em crianças de um nível social baixo. Rev. Period., v.7, n.1, p.6-10, jan./abr. 1998.

19 - DAHLEN,G. et al. Biochemical and serological characterization of Bacteroides intermedius strains isolated from the deep periodontal pocket. J.clin.Microbiol., v.28, n.10, p.2269-74, Oct. 1990.

20 - DAHLLÖF, G. et al. Caries, gingivitis, and dental abnormalities in preschool children with cleft lip and/or palate. Cleft Palate J., v. 26, n.3, p. 233-8, July 1989.

21 - DELANEY, J.E.; RATZAN, S.K.; KORNMAN, K.S. Subgingival microbiota associated with puberty: studies of pre -, circum - and postpubertal human females. Pediat. Dent., v.8, n.4, p.268-75, Dec. 1986.

22 - DZINK, J.L.; SOCRANSKY, S.S.; HAFFAJEE, A.D. The predominant cultivable microbiota of active and inactive lesions of destructive periodontal diseases. J. clin. Periodont., v.15, n.5, p.316-23, May 1988. 
23 - FONSECA, L. Relação entre o teste BANA da placa subgengival e os níveis de inflamação gengival e presença de espiroquetas em crianças brasileiras. Araraquara, 1990. 137p. Dissertação (Mestrado) Faculdade de Odontologia de Araraquara, Universidade Paulista Júlio de Mesquita Filho.

24 - FRISKEN, K.W.; HIGGINS, T.; PALMER, J.M. The incidence of periodontopathic microorganisms in young children. Oral Microbiol. Immunol., v.5, n.1, p.43-5, Feb. 1990.

25 - FRISKEN, K.W. et al. Suspected periodontopathic microorganisms and their oral habitats in young children. Oral Microbiol. Immunol., v.2, n.2, p.604, June 1987.

26 - FUKUI, K. et al. Incidence of Prevotella intermedia and Prevotella nigrescens carriage among family members with subclinical periodontal disease. J. clin. Microbiol., v. 37, n.10, p.3141-5, Oct. 1999.

27 - GAGGL, A. et al. Periodontal disease in patients with cleft palate and patients with unilateral and bilateral clefts of lip, palate and alveolus. J.Periodont., v.70, n.2, p.171-8, Feb. 1999.

28 - GENCO, R.J. Current view of risk factors for periodontal diseases. J. Periodont., v.67, p. 1041-9, Oct. 1996. Suppl. 10. 
29 - GHARBIA, S.E. et al. Characterization of Prevotella intermedia and Prevotella nigrescens isolates from periodontic and endodontic infections. J.Periodont., v.65, n.1, p.56-61, Jan.1994.

30 - GMÜR; R.; GUGGENHEIM, B. Antigenic heterogeneity of Bacteroides intermedius as recognized by monoclonal antibodies. Infect. Immun., v.42, n.2, p.459-70, Nov. 1983.

31 - GMÜR, R.; GUGGENHEIM,B. Interdental supragingival plaque - a natural habitat of Actinobacillus actinomycetemcomitans, Bacteroides forsythus, Campylobacter rectus and Prevotella nigrescens. J. dent. Res., v.73, n.8 p.1421-1428, Aug. 1994.

32 - GREENSTEIN,G.; LAMSTER,I. Bacterial transmission in periodontal diseases: a critical review. J.Periodont., v.68, n.5, p.421-31, May 1997.

33 - HAFFAJEE, A.D.; SOCRANSKY, S.S. Microbial etiological agents of destructive periodontal diseases. Periodontol. 2000, v.5, p.78-111, June 1994.

34 - HAFFAJEE, A.D. et al. Microbial risk indicators for periodontal attachment loss. J. Periodont. Res., v.26, n.3, p.293-6, May 1991. 
35 - HUGOSON, A.; KOCH, G; RYLANDER, H. Prevalence and distribution of gingivitis-periodontitis in children and adolescents. Swed. dent. J., v.5 n.3, p. 91-103, 1981.

36 - JAHN, M.R.; JAHN, R.S. Fique atento: criança também tem gengivite. Rev. Ass. paul. cirurg. Dent., v.51, n.4, p.355-8, jul./ago. 1997.

37 - JOHANSON, B. et al. A follow-up study of cleft lip and palate patients treated with orthodontics, secondary bone grafting and prosthetic rehabilitation. Scand J. Plast. Reconstr. Surg., v.8, n.1-2, p. 121-35, 1974.

38 - JOHNSON, J. L.; HOLDEMAN, L. V. Bacteroides intermedius comb.nov. and descriptions of Bacteroides corporis sp.nov. and Bacteroides levii sp.nov. Int. J. Syst. Bacteriol., v.33, p.15-25, 1983.

39 - JOUSIMIES-SOMER, H.R. Update on the taxonomy and the clinical and laboratory characteristics of pigmented anaerobic gram-negative rods. Clin. Infect. Dis., v.20, p.S187-S91, June 1995. Suppl.2.

40 - KELSTRUP, J. The incidence of Bacteroides melaninogenicus in human gingival sulci and its prevalence in the oral cavity at different ages. Periodontics, v.4, n.1, p.14-8, Jan./Feb. 1966. 
41 - KISBY, L.E. et al. DNA probe detection of key periodontal pathogens in juveniles. J.Pedod., v.13, n.3, p.222-30, Spring 1989.

42 - KÖNÖNEN, E. Pigmented Prevotella species in the periodontally healthy oral cavity. FEMS Immunol. Med. Microbiol., v.6, n.2-3, p.201-5, Mar. 1993.

43 - KÖNÖNEN, E.; ASIKAINEN, S.; JOUSIMIES-SOMER, H. The early colonization of Gram-negative anaerobic bacteria in edentulous infants. Oral Microbiol. Immunol., v.7, n.1, p.28-31, Feb. 1992.

44 - KÖNÖNEN, E.; JOUSIMIES-SOMER, H.; ASIKAINEN, S. Relationship between oral Gram-negative anaerobic bacteria in saliva of the mother and the colonization of her edentulous infant. Oral Microbiol. Immunol., v.7, n.5, p.273-6, Oct. 1992.

45 - KÖNÖNEN, E. et al. The oral Gram-negative anaerobic microflora in young children : longitudinal changes from edentulous to dentate mouth. Oral Microbiol. Immunol., v.9, n.3, p.136-41, June 1994.

46 - KÖNÖNEN, E. et al. Biochemical and genetic characterization of a Prevotella intermedia/nigrescens-like organism. Int.J.Syst.Bacteriol., v.48, Pt.1, p.39-46, Jan. 1998. 
47 - KÖNÖNEN, E. et al. Phylogenetic characterization and proposal of a new pigmented species to the genus Prevotella: Prevotella pallens sp. nov. Int.J.Syst.Bacteriol., v.48, Pt.1, p.47-51, Jan.1998.

48 - KÖNÖNEN, E. et al. Establishment of oral anaerobes during the first year of life. J. dent. Res., v.78, n.10, p.1634-9, Oct. 1999.

49 - LISTGARTEN, M.A. The structure of dental plaque. Periodontol. 2000, v.5, p.52-65, June 1994.

50 - LÖE, H. The gingival index, the plaque index and the retention index systems. J.Periodont., v.38, n.6, p.610-6, Nov./Dec. 1967. Supplement.

51 - LÖE, H.; THEILADE, E.; JENSEN, S.B. Experimental gingivitis in man. J. Periodont., v.36, p.177-87, May/June 1965.

52 - LOESCHE, W.J. The role of spirochetes in periodontal disease. Adv.dent.Res., v.2, n.2, p.275-83, Nov. 1988.

53 - MACKLER, S.B.; CRAWFORD, J.J. Plaque development and gingivitis in the primary dentition. J.Periodont., v.44, n.1, p.18-24, Jan. 1973. 
54 - MAEDA, N. et al. Incidence of Prevotella intermedia and Prevotella nigrescens in periodontal health and disease. Microbiol. Immunol., v.42, n.9, p. 583-9, 1998.

55 - MARTINS, A.A.O.; VIGGIANO, R.D.; HALLA, D. Gengivite em crianças. Prevalência e severidade na faixa etária de 3 a 6 anos de idade, em ambos os sexos. Rev. gaucha Odont., v.36, n.2, p.141-5, mar./abr. 1988.

56 - MATSSON, L. Development of gingivitis in pre-school children and young adults. J.clin.Periodont., v.5, n.1, p.24-34, May 1978.

57 - MATSSON, L. Factors influencing the susceptibility to gingivitis during childhood - a review. Int.J.Paed.Dent., v.3, n.3, p.119-27, Sept. 1993.

58 - MATSSON, L.; GOLDBERG, P. Gingival inflammatory reaction in children at different ages. J.clin.Periodont., v.12, n.2, p.98-103, Jan./May 1985.

59-MÄTTÖ, J. et al. Distribution and genetic analysis of oral Prevotella intermedia and Prevotella nigrescens. Oral Microbiol.Immunol., v.11, n.2, p.96-102, Apr. 1996.

60 - MAZAHERI, M. et al. Changes in arch form and dimensions of cleft patients. Am. J. Orthod., v. 60, n.1, p. 19-32, July 1971. 
61 - McCLELLAN, D.L.; GRIFFEN, A.L.; LEYS, E.J. Age and prevalence of Porphyromonas gingivalis in children. J. clin. Microbiol., v.34, n.8, p.2017-9, Aug. 1996.

62 - MIKX, F.H.M.; MATEE, M.I.; SCHAEKEN, M.J.M. The prevalence of spirochetes in the subgingival microbiota of Tanzanian and Dutch children. J.clin.Periodont., v.13, n.4, p.289-93, Apr. 1986.

63 - MISHKIN, D.J. et al. Prepubertal periodontitis: a recently defined clinical entity. Pediat.Dent., v.8, n.3, p.235-8, Sept.1986.

64 - MOMBELLI, A.; BRÄGGER, U.; LANG, N.P. Microbiota associated with residual clefts and neighboring teeth in patients with cleft lip, alveolus and palate. Cleft Palate-Craniof. J., v.29, n.5, p.463-9, Sept. 1992.

65 - MOORE, L.V.H. et al. Bacteriology of human gingivitis. J. dent. Res., v.66, n.5, p.989-95, May 1987.

66 - MOORE, W.E.C. et al. Bacteriology of experimental gingivitis in young adults human. Infect. Immunol., v. 38, n.2, p. 651-67, Nov. 1982.

67 - MOORE, W.E.C. et al. Bacteriology of severe periodontitis in young adults human. Infect. Immunol., v.38, n.3, p.1137-48, Dec. 1982. 
68 - MOORE, W.E.C. et al. Bacteriology of experimental gingivitis in children. Infect.Immunol., v.46, n.1, p.1-6, Oct. 1984.

69 - MOORE, W.E.C. et al. The microflora of periodontal sites showing active destructive progression. J.clin.Periodont., v.18, n.10, p.729-39, Nov. 1991.

70 - MORHART, R.E. et al. A microbiological and biochemical study of gingival crevice debris obtained from Guatemalan Mayan Indians. J. Periodont., v. 41, n. 11, p. 644-9, Nov. 1970.

71 - MOUTON, C. et al. Serum antibodies to oral Bacteroides assacharolyticus (Bacteroides gingivalis): relationship to age and periodontal disease. Infect. Immunol., v.31, n.1, p.182-92, Jan. 1981

72 - MUKHERJEE, M. et al. Darkfield microscopy of subgingival plaque in children. J.dent.Res., v.64, p.200, 1985. Special issue/Abstract n. 227/

73 - NAKAGAWA, S. et al. Subgingival microflora in children of early childhood, school age and circumpuberty. The proportion and frequency of Gramnegative bacteria in periodontally healthy and gingivitis groups. Shoni Shikagaku Zasshi., v.29, n.1, p.72-85, 1991. 
74 - NAKAGAWA, S. et al. Infection by Porphyromonas gingivalis and Actinobacillus actinomycetemcomitans, and antibody responses at different ages in humans. J.Periodont.Res., v.29, n.1, p.9-16, Jan. 1994.

75 - PAUL, T.; BRANDT, R. S. Oral and dental health status of children with cleft lip and/or palate. Cleft Palate-Craniof. J., v. 35 n. 4, p. 329-32, July 1998.

76 - PEDERSON, E.D. et al. Trypsin-like activity levels of Treponema denticola and Porphyromonas gingivalis in adults with periodontitis. J.clin.Periodont., v.21, n.8, p.519-25, Sept. 1994.

77 - PERETZ, B.; MACHTEI, E.M.; BIMSTEIN, E. Changes in periodontal status of children and young adolescents: a one year longitudinal study. J. clin. Pediat. Dent., v.18, n.3, p.3-6, Spring 1996.

78 - PETIT, M.D. et al. Prevalence of periodontitis and suspected periodontal pathogens in families of adult periodontitis. J.clin.Periodont., v.21, n.2, p.76-85, Feb. 1994.

79 - RAMSTAD, T. Periodontal condition in adult patients with unilateral complete cleft lip and palate. Cleft Palate J., v. 26, n.1, p.14-20, Jan. 1989. 
80 - RANTA, R. A review of tooth formation in children with cleft lip/palate. Am. J. Orthod., v.90, n.1, p.11-8, July 1986.

81-ROBERT, J.C.; MOUTON, C. Bacteroides gingivalis and other blackpigmented Bacteroides in children. J.dent.Res., v.68, p.987, 1989. Special issue /Abstract n.961/.

82 - ROSA, O.P.S. Prevalência de microrganismos na placa subgengival de dentição decídua. Bauru, 1995. 152p. Tese (Livre-Docência) - Faculdade de Odontologia de Bauru, Universidade de São Paulo.

83 - ROSA, O.P.S. et al. Periodontopatógenos na saliva e placa subgengival em um grupo de mães. REUNIÃO CIENTÍFICA DA SOCIEDADE BRASILEIRA DE PESQUISA ODONTOLÓGICA, 16., Águas de São Pedro, 1999. Anais. São Paulo, SBPqO, 1999.

84 - ROSS, R.B. The management of dental arch deformity in cleft lip and palate. Clin. Plast. Surg., v.2, n.2, p. 325-42, Apr. 1975.

85 - SAVITT, E.D. et al. Comparison of cultural methods and DNA probe analysis for the detection of Actinobacillus actinomycetemcomitans, Bacteroides gingivalis and Bacteroides intermedius in subgingival plaque samples. J.Periodont., v.59, n.7, p.431-8, July 1988. 
86 - SAWYER, D.R. et al. Comparison of oral microflora between well-nourished and malnourished Nigerian children. J.dent.Child., v.53, n.6, p.439-43, Nov./Dec. 1986.

87 - SCHULTES, G.; GAGGL, A.; KÄRCHER, H. Comparison of periodontal disease in patients with clefts of palate and patients with unilateral clefts of lip, palate and alveolus. Cleft Palate-Craniof. J., v.36, n.4, p.322-7, July 1999.

88 - SEMB; G.; RAMSTAD, T. The influence of alveolar bone grafting on the orthodontic and prosthodontic treatment of patients with cleft lip and palate. Dent. Update, v.26, n.2, p.60-4, Mar. 1999.

89 - SHAH, H.N.; GHARBIA, S.E. Biochemical and chemical studies on strains designated Prevotella intermedia and proposal of a new pigmented species, Prevotella nigrescens sp. nov. Int.J.Syst.Bacteriol., v.42, n.4, p.542-6, Oct. 1992.

90 - SHAH, C.P.; WONG, D. Management of children with cleft lip and palate. Can. Med. Assoc. J., v. 122, n.1, p.19-24, Jan. 1980.

91 - SIMONSON, L.G. et al. Bacterial synergy of Treponema denticola and Porphyromonas gingivalis in a multinational population. Oral Microbiol. Immunol., v.7, n.2, p.111-2, Apr. 1992. 
92 - SIMONSON, L.G. et al. Treponema denticola and Porphyromonas gingivalis as prognostic markers following periodontal treatment. J.Periodont., v.63, n.4, p.270-3, Apr.1992.

93 - SIXOU, J.L.; BONNAURE-MALLET, M.; MOUTON, C. Serum antibodies to Porphyromonas gingivalis in children. J. Periodont., v.66, n.5, p.369-76 , May 1995.

94 - SLOTS, J. Importance of black-pigmented Bacteroides in human periodontal disease. In: GENCO,R.; MERGENHAGEN, S.E., eds. Host-parasite interactions in periodontal diseases. Washington, American Society for Microbiology, 1982. p.62-75.

95 - SLOTS, J.; GENCO, R. Black-pigmented Bacteroides species, Capnocytophaga species and Actinobacillus actinomycetemcomitans in human periodontal disease: virulence factors in colonization, survival, and tissue destruction. J. dent. Res., v.63, n.3, p.412-21, Mar. 1984.

96 - SLOTS, J.; RAMS, T.E. Microbiology of periodontal disease. In : SLOTS, J.; TAUBMAN, M.A. eds. Contemporary oral microbiology and immunology. St. Louis, Mosby, 1992. p.425-42. 
97 - SOCRANSKY, S.S. Criteria for the infectious agents in dental caries and periodontal disease. J.clin.Periodont., v.6, n.7, p.15-21, Dec.1979.

98 - SOCRANSKY, S.S.; HAFFAJEE, A.D. The bacterial etiology of destructive periodontal disease: current concepts. J.Periodont., v.63, p.322-31, Apr. 1992. Suppl. 4.

99 - SOCRANSKY, S.S.; MANGANIELLO, S.D. The oral microbiota of man from birth to senility. J. Periodont., v.42, n.8, p.485-94, Aug. 1971.

100 - SOCRANSKY, S.S. et al. Microbial complexes in subgingival plaque. J. clin. Periodont., v.25, n.2, p.134-44, Feb. 1998.

101 - SPENCER, J.A.; BEIGHTON, D.; HIGGINS, T.J. Periodontal disease in five and six-year old children. J. Periodont., v.54, n.1, p.19-22, Jan. 1983.

102 - SPINA, V. et al. Classificação das fissuras lábio palatinas: sugestão de modificação. Rev. Hosp. Clin. Fac. Med. S. Paulo, v.27, p.5-6, 1972.

103 - SWEENEY, E.A. et al. Prevalence and microbiology of localized prepubertal periodontitis. Oral Microbiol.Immunol., v.2, n.2, p.65-70, June 1987. 
104 - TANG, E.L.K.; SO L.Y.S. Prevalence and severity of maloclusion in children with cleft lip and/or palate in Hong Kong. Cleft Palate-Craniof. J., v. 29, n.3, p.287-91, May 1992.

105 - TANNER A. et al. Clinical, microbiological and immunological profile of healthy, gingivitis and putative active periodontal subjects. J. Periodont. Res., v.31, n.3, p.195-204, Apr. 1996.

106 - TANNER, A.C.R. et al. Diagnosis of periodontal disease using rapid identification of "activity related" Gram negative species. J.Periodont.Res., v.22, n.3, p.207-8, May 1987.

107 - TEANPAISAN, R.; DOUGLAS, C.W.; WALSH, T.F. Characterisation of black-pigmented anaerobes isolated from diseaded and healthy periodontal sites. J. Periodont. Res., v.30, n.4, p.245-51, July 1995.

108 - TEJA, Z.; PERSSON, R.; OMNELL, M. L . Periodontal status of teeth adjacent to nongraft unilateral alveolar clefts. Cleft Palate-Craniof. J., v.29, n.4, p.357-62, July 1992.

109 - TOLEDO, B.E.C. Contribuição para o estudo da prevalência de gengivite em escolares da cidade de Araraquara, brancos, nascidos no Brasil. Rev. Fac. Farm. Odont. Araraq., v.1, n.1, p.39-65, jan./jun. 1967. 
110 - TUITE-MCDONNELL, M. et al. Concordance of Porphyromonas gingivalis colonization in families. J. clin. Microbiol., v.35, n.2, p.455-61, Feb. 1997.

111 - TURNER, C. et al. Oral health status of russian children with unilateral cleft lip and palate. Cleft Palate-Craniof. J., v.35, n.6, p.489-94, Nov. 1998.

112 - UMEDA, M. et al. Risk indicators for harboring periodontal pathogens. J. Periodont., v.69, n.10, p. 1111-8 Oct. 1998.

113 - VAN OOSTEN, M.A.C. et al. Black-pigmented Bacteroides and spirochetes in the subgingival microbiota of prepubertal schoolchildren. J.Periodont.Res., v.23, n.3, p.199-203, May 1988.

114 - VAN POPERIN, N.; LOPATIN, D.E. Slot immunoblot assay for detection and quantitation of periodontal disease-associated microorganisms in dental plaque. J.clin.Microb., v.29, n.11, p.2554-8, Nov. 1991.

115 - VAN STEENBERGEN, T.J.M. et al. Distribution and transmission of Prevotella intermedia among family members. J.dent.Res., v.74, p.587, June/July 1995. Special issue/Abstract n.1489/ 
116 - VAN STEENBERGEN, T.J.M. et al. Intra-familial transmission and distribution of Prevotella intermedia and Prevotella nigrescens. J.Periodont.Res., v.32, n.4, p.345-50, May 1997.

117 - VAN WINKELHOFF, A.J. et al. Black-pigmented Bacteroides and motile organisms on oral mucosal surfaces in individuals with and without periodontal breakdown. J.Periodont.Res., v.21, n.4, p.434-9, July 1986.

118 - VERTUAN, V.; TOLEDO, B.E.C.; MENDES, A.D.J. Condições de saúde bucal em diferentes classes sociais. Parte II: doença periodontal e higiene oral. Relações com o sexo, raça e idade. Rev. Ass. paul. cirurg. Dent., v.31, n.2, p.120-4, mar./abr. 1977.

119 - WALSH, L.J. et al. The immunohistology of chronic gingivitis in children. Pediat. Dent., v.9, n.1, p. 26-32, Mar. 1987.

120 - WATSON, M.R.; BRETZ, W.A.; LOESCHE, W.J. Presence of Treponema denticola and Porphyromonas gingivalis in children correlated with periodontal disease of their parents. J.dent.Res., v.73, n.10, p.1636-40, Oct. 1994.

121 - WATSON, M.R. et al. Detection of two anaerobic periodontopathogens in children by means of the BANA and ELISA assays. J.dent.Res., v.70, n.7, p.1052-6, July 1991. 
122 - WHITE, D.; MAYRAND, D. Association of oral Bacteroides with gingivitis and adult periodontitis. J.Periodont.Res., v.16, n.3, p.259-65, May 1981.

123 - WILLIAMS, B.L. et al. Assessment of serum antibody patterns and analysis of subgingival microflora of members of a family with a high prevalence of early-onset periodontitis. Infect.Immun., v.49, n.3, p.742-50, Sept.1985.

124 - WOJCICKI, C.J.; HARPER, D.S.; ROBINSON, P.J. Differences in periodontal disease-associated microorganisms of subgingival plaque in prepubertal, pubertal and postpubertal children. J. Periodont., v.58, n.4, p.219-23, Apr. 1987.

125 - WONG, F. W. L.; KING, N. M. The oral health of children with clefts - a review. Cleft Palate-Craniof. J., v.35, n.3, p.248-54, May 1998.

126 - ZAMBON, J.J.; REYNOLDS, H.S.; SLOTS, J. Black-pigmented Bacteroides spp. in the human oral cavity. Infect.Immun., v.32, n.1, p.198-203, Apr. 1981. 
Abstract 


\section{ABSTRACT}

\section{Clinical and microbiological evaluation of periodontal condition in 5 - 6 years old children with unilateral complete cleft lip and palate compared to normal controls.}

Children with cleft lip and palate have difficulty in achieving optimal tooth cleaning, mainly in maxillary anterior segment, because the anatomy of the cleft area and the residual scar tissue after surgical procedures. The purpose of this study was to compare the clinical and microbiological conditions of cleft and noncleft children through the evaluation of oral hygiene and gingival status, and the detection of $P$. gingivalis, $P$. nigrescens and $T$. denticola in subgingival dental plaque, using the Slot Immunoblot technique. A total of 57 children, with primary dentition and 5-6 years old was evaluated, including 30 with unilateral cleft lip and palate (experimental group) and 27 children without clefts (control group). To evaluate clinically the children, the Plaque Index (PI) and the Gingival Index (GI) described by Löe (1967) were utilized. The mean PI in the experimental group was higher $(1.82 \pm 0.38)$ than that in control group $(1.63 \pm 0.38)$, but there was no statistically significant difference. On the other hand, the mean $\mathrm{Gl}$ in the experimental group $(1.05 \pm 0.22)$ was found to be significantily higher than that of the control group $(0.79 \pm 0.33)(p<.05)$. In the experimental group the cleft area $(2$ sites), with mean PI of $2.04 \pm 0.58$ and mean Gl of $1.11 \pm 0.26$, when compared to the posterior area (4 sites), with mean PI of $1.74 \pm 0.37$ and mean GI of $1.04 \pm 0.26$, showed statistically significant difference $(\mathrm{p}<.05)$ only as to the $\mathrm{PI}$. In relation to the 
severity, most of the children in both experimental and control groups presented a moderate PI degree (73.33\% and $81.48 \%$, respectively), and a high prevalence of mild gingivitis (53.33\% and $70.37 \%$, respectively). When the groups were compared as to the PI and Gl severity degrees, no difference were observed, the same ocurring with the comparison between areas in the experimental group. The analysis of the anaerobic Gram negative organisms showed that $P$. nigrescens was detected in $16.67 \%$ of the experimental group and $11.11 \%$ of the control group whereas $P$. gingivalis and $T$. denticola were not detected. Children with unilateral cleft lip and palate showed greater gingival inflammation than noncleft children, despite of the same plaque amount and the same percentage of the investigated microrganisms. 